TURKEY AS A MAJOR GAS TRANSIT HUB COUNTRY

\author{
A THESIS SUBMITTED TO \\ THE GRADUATE SCHOOL OF NATURAL AND APPLIED SCIENCES \\ OF \\ MIDDLE EAST TECHNICAL UNIVERSITY
}

BY

TAYFUN YENER UMUCU

IN PARTIAL FULFILLMENT OF THE REQUIREMENTS

FOR

THE DEGREE OF DOCTOR OF PHILOSOPHY

IN

PETROLEUM \& NATURAL GAS ENGINEERING

OCTOBER 2008 
Approval of the Thesis:

\section{TURKEY AS A MAJOR GAS TRANSIT HUB COUNTRY}

submitted by TAYFUN YENER UMUCU in partial fulfillment of the requirements for the degree of Doctor of Philosophy in Petroleum and Natural Gas Engineering by,

Prof. Dr. Canan ÖZGEN

Dean, Graduate School of Natural and Applied Sciences

Prof. Dr. Mahmut PARLAKTUNA

Head of Department, Petroleum and Natural Gas Engineering

Prof. Dr. Mustafa Verşan KÖK

Supervisor, Petroleum and Natural Gas Engineering Dept., METU

Prof. Dr. Meliha ALTUNIŞIK

Co-Supervisor, International Relations Dept., METU

\section{Examining Committee Members:}

Prof. Dr. Mahmut PARLAKTUNA

Petroleum and Natural Gas Engineering Dept., METU

Prof. Dr. Mustafa Versan KÖK

Petroleum and Natural Gas Engineering Dept., METU

Prof. Dr. Meliha ALTUNIŞIK

International Relations Dept., METU

Assoc. Dr. Oktay TANRISEVER

International Relations Dept., METU

Assoc. Dr. Mitat ÇELIKPALA

International Relations Dept., TOBB University of Economics and Technology, Ankara

Date: 
I hereby declare that all information in this document has been obtained and presented in accordance with academic rules and ethical conduct. I also declare that, as required by these rules and conduct, I have fully cited and referenced all material and results that are not original to this work.

Tayfun Yener UMUCU 


\author{
ABSTRACT \\ TURKEY AS A MAJOR GAS TRANSIT HUB COUNTRY \\ UMUCU Tayfun Yener \\ Ph.D., Department of Petroleum \& Natural Gas Engineering \\ Supervisor: Prof. Dr. Mustafa Verşan KÖK \\ Co-supervisor: Prof. Dr. Meliha ALTUNIŞIK
}

October 2008, 94 pages

The demand for natural gas has been growing much faster than the demand for other primary resources and it is expected that the European Union (EU)'s dependency on natural gas will continue to grow. For this reason gas supply security policy has been more important lately than before on the European political agenda in securing a smooth supply of gas. According to the EU external policy directives, EU natural gas energy security can be enhanced by diversifying geographical origin as well as transit routes.

Turkey in that concept was assumed as one of the important transit hub countries to reach the new sources in the Azerbaijan and Central Asia region as well as in the Middle East.

However, the transportation of gas from this region to Europe through the new route via Turkey has become very complex issue in terms of technical and political point of view arising from suppliers within their export policy and from the U.S's bilateral sanctions.

This dissertation argues that under the present circumstances especially due to the difficulties in the supplier side being a major transit gas hub country will be very difficult for Turkey combined with the increasing internal gas demand in the next decade.

Keywords: Natural Gas, EU, Supply Security, Transit hub, Turkey 


\title{
öz
}

\section{ANA GAS TRANSIT HUB ÜLKE KONUMUNDA TÜRKIYE}

\author{
UMUCU, Tayfun Yener \\ Doktora, Petrol ve Doğal Gaz Mühendisliği Bölümü \\ Tez Yöneticisi: Prof. Dr. Mustafa V. KÖK \\ Ortak Tez Yöneticisi: Prof. Dr. Meliha ALTUNIŞIK
}

Ekim 2008, 94 sayfa

Bilindiği üzere doğal gaza olan ilgi hızlı bir şekilde artmakta olup Avrupa Birliği (AB)' de doğal gaza karşı daha fazla ilgi duymaktadır. Bu nedenle doğal gaz sağlamaya yönelik enerji güvenliği Avrupa politikasında önceki zamanlara nazaran daha önemli bir yer tutmaya başlamıştır.

Avrupa Birliğinin dış politika direktiflerine göre doğal gaz arz güvenliği kaynak bölgelere ilaveten temin güzergahlarınında çeşitlendirilmesiyle artırılabilecektir.

Türkiye bu kapsamda Hazar bölgesinin iki tarafında ve Orta Doğu daki yeni kaynaklara ulaşmak için önemli bir transit ve bu ülkelerin kaynaklarının birleşme yeri olarak önem kazanmıştır.

Ancak söz konusu kaynakların Türkiye üzerinden taşınması teknik ve politik zorluklarıda beraberinde getirmiştir. Üretici ülkelerin ihraç politikaları ve Amerika Birleşik Devletlerinin bölgede tek taraflı politikası Türkiye üzerinden yeterli bir gaz hacminin taşınmasını zorlaştırmaktadır.

Günümüz koşullarında özellikle üreticinin ihrac politikasına bağlı olarak Türkiye'nin bir ana transit hub ülkesi olma şansı kendi iç bünyesinde artan talep gereksinimi nedeniylede oldukça zayıf kalmaktadır.

Anahtar kelimeler: Doğal Gaz, AB, Arz Güvenliği, Transit hub, Türkiye 
To My Family 


\section{ACKNOWLEDGEMENTS}

I would like to express my sincere gratitude to my supervisor Prof. Dr. Mustafa Verşan KÖK and co-supervisor Prof. Dr. Meliha ALTUNIŞIK for their guidance, advice, criticism, encouragements and insight throughout the study.

I would like to thank to Examining Committee Members, Prof. Dr. Mahmut PARLAKTUNA, Assoc. Prof. Dr Oktay TANRISEVER, and Assoc. Prof. Dr. Mitat ÇELIKPALA for their constructive comments and contributions to the study. 


\section{TABLE OF CONTENTS}

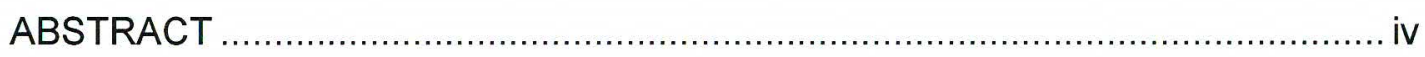

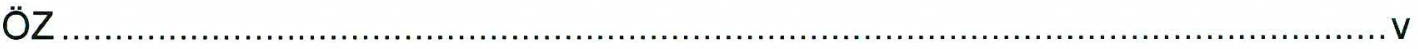

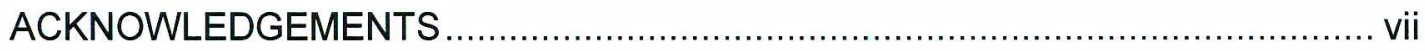

TABLE OF CONTENTS ................................................................................ vii

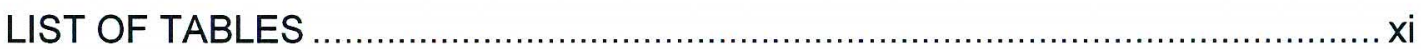

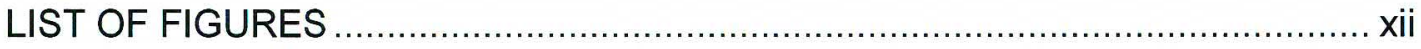

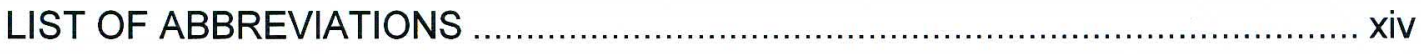

CHAPTER

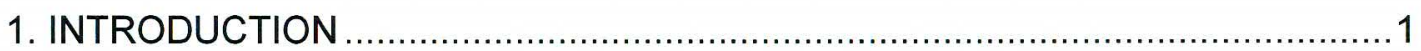

2. THE EUROPEAN UNION GAS DEMAND AND SUPPLY: SECURITY OF

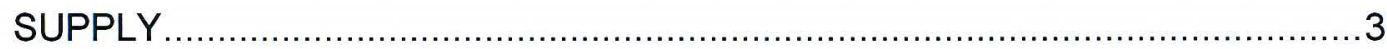

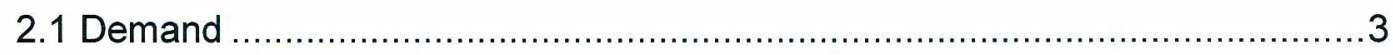

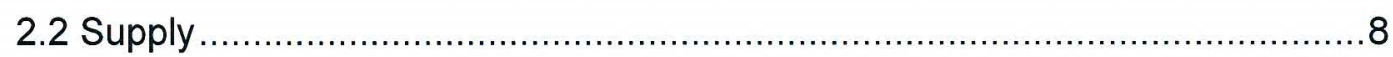

2.2.1 Indigenous Reserves and Supply ............................................ 8

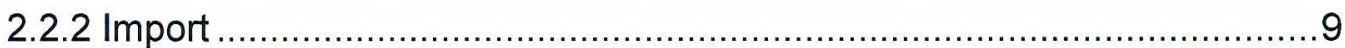

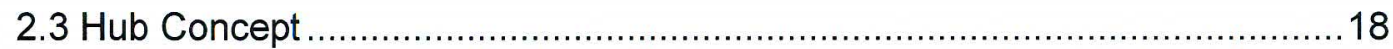

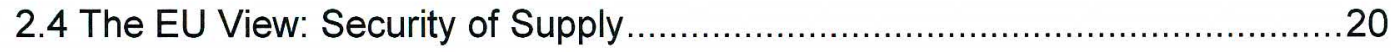

3. PRODUCING COUNTRIES: EXPORT POTENTIALS …...............................26

3.1 Overview of Infrastructure: Present Status ............................................27

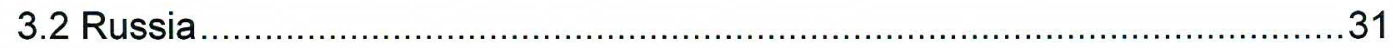

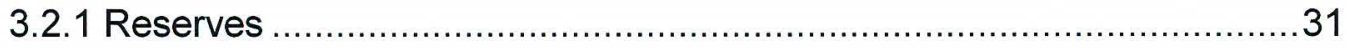

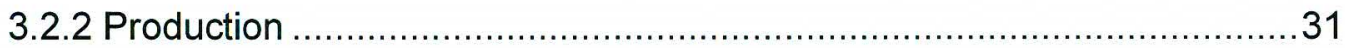

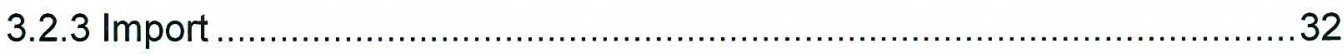




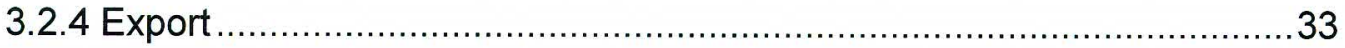

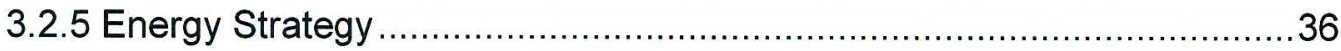

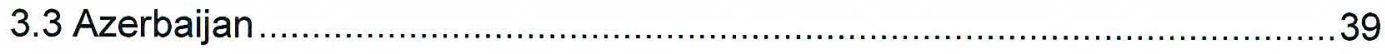

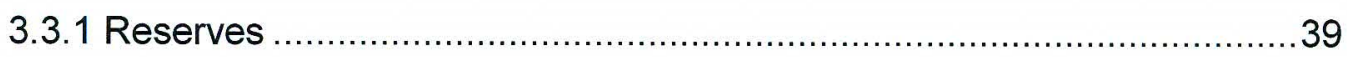

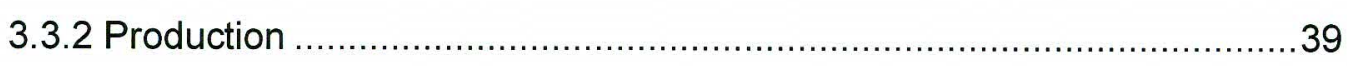

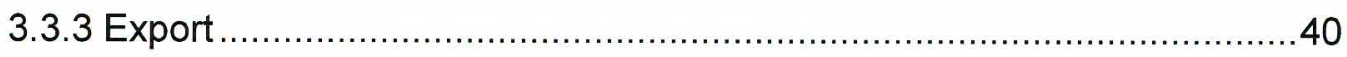

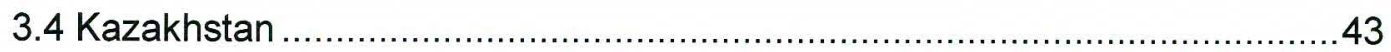

3.4.1 Reserves ................................................................................ 43

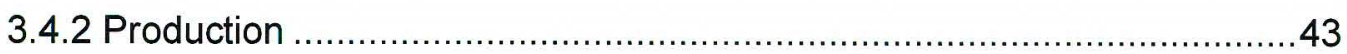

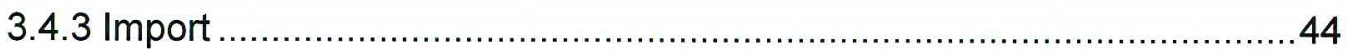

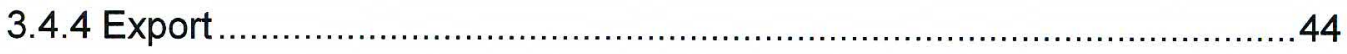

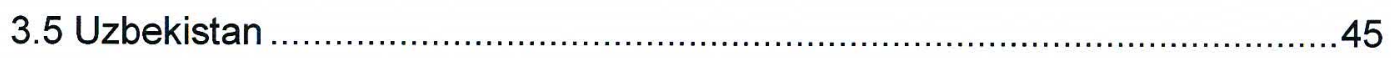

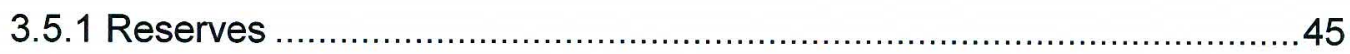

3.5.2 Production .............................................................................. 45

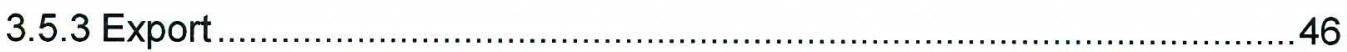

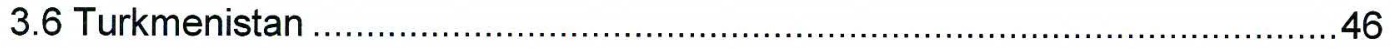

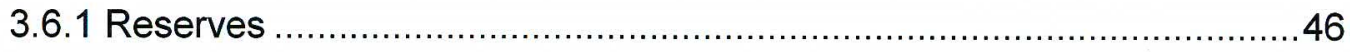

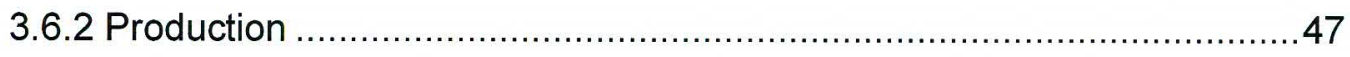

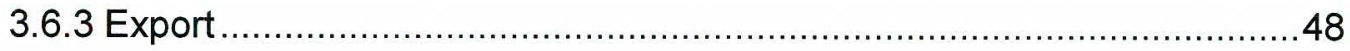

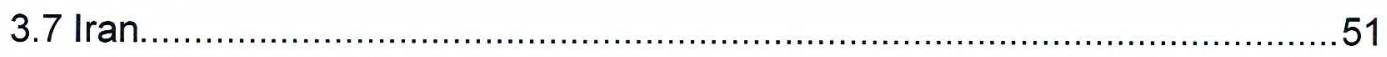

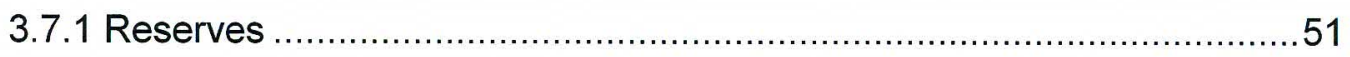

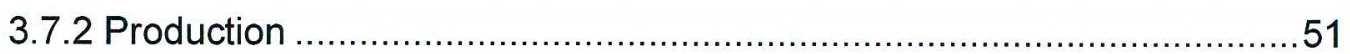

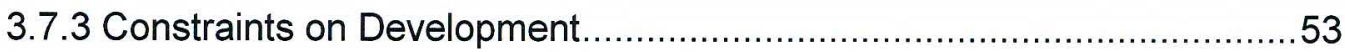

3.7.3.1 Internal Constraints: The Constitution and Investment Policy ...........53

3.7.3.2 External Constraint: Global Politics ..............................................53

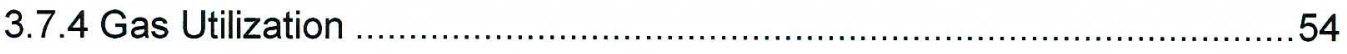

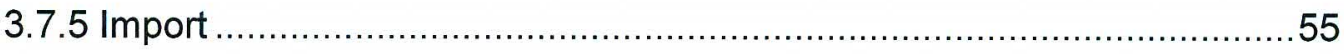

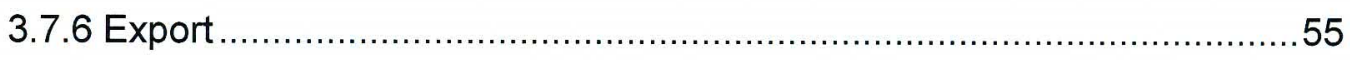

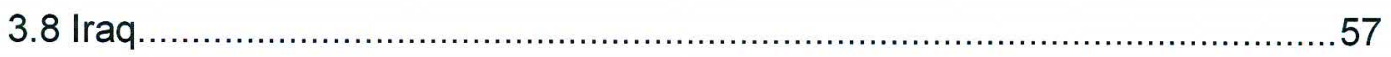

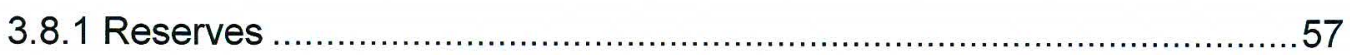

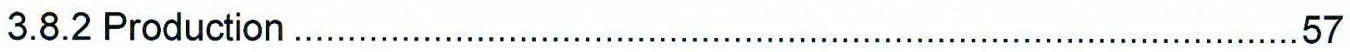

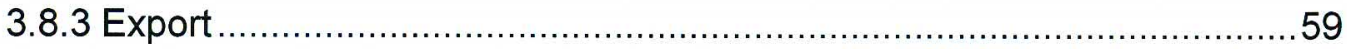


4. STATEMENT OF PROBLEM: TURKEY AND ITS OBJECTIVES

4.1 Turkey's Gas Policy 61

4.2 Internal Dynamics: Policy Bodies 63

4.3 Demand and Supply: Gas Balance. 68

4.4 Infrastructure: Existing and Proposed Future Gas Pipelines 69

4.4.1 Existing Pipelines and LNG Regasification Terminals. 69

4.4.2 Proposed Pipelines 72

5. RESULTS AND DISCUSSIONS 79

6. CONCLUSION. 84

REFERENCES 87

CURRICULUM VITAE . .95 


\section{LIST OF TABLES}

\section{TABLES}

Table 2.1 The EU regional import dependency [Source data: 7] ...................... 14

Table 2.2 The EU supply challenge [Source data: 2, 12] ............................... 15

Table 2.3 The EU import pipeline capacity [Source data: 1] ............................17

Table 2.4 LNG export capacity of neighbor producers to the EU

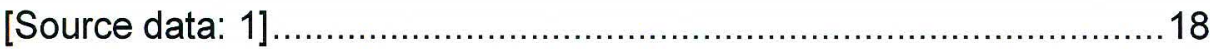

Table 4.1 Turkey main gas transmission network capacity, Bcm/yr

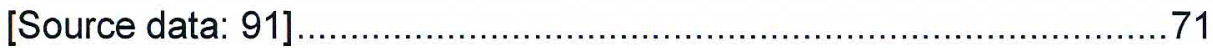

Table 5.1 Export possibilities of producing countries for the EU, Bcm/yr............82 


\section{LIST OF FIGURES}

\section{FIGURES}

Figure 2.1 Comparison: Institutional projections for the EU gas demand [1, 2] .....4

Figure 2.2 The EU primary energy demand, Mtoe/yr [Source data: 2] ..................4

Figure 2.3 The EU primary energy demand, \% [Source data: 2] ........................5

Figure 2.4 The EU share of natural gas in primary energy demand at the Member State basis, \% [Source data: 2] ....................................................

Figure 2.5 The EU projections for different gas prices A) Mtoe/yr, B) \% [Source data: 5]

Figure 2.6 The EU projection for natural gas demands of the Member States

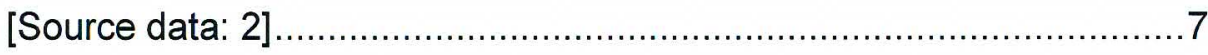

Figure 2.7 The EU indigenous reserves profile [Source data: 7] .......................8

Figure 2.8 The EU indigenous production [Source data: 2] ..............................

Figure 2.9 The EU projection for domestic supply profile of the Member States

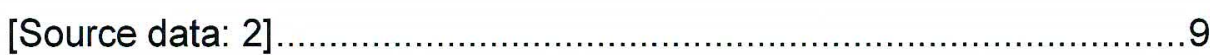

Figure 2.10 The EU main natural gas import routes [8] ....................................10

Figure 2.11 The EU gas import origin, 2006 [Source data: 7] ...........................10

Figure 2.12 The EU projection for natural gas import of the Member States

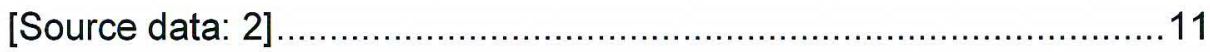

Figure 2.13 The EU demand balance \%, 2006 [Source data: 7] ........................11

Figure 2.14 The EU regional import dependency profile [9] ............................12

Figure 2.15 The EU suppliers share in imports, 2006 [Source data: 7] ................12

Figure 2.16 The EU regional division [10] ............................................... 13

Figure 2.17 The EU supply challenges in natural gas demand, $\mathrm{Bcm} / \mathrm{yr}$ [Source data: 2, 12] 15

Figure 2.18 The EU supply challenge in natural gas demand, \%

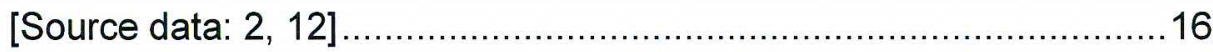

Figure 2.19 The EU operational and proposed main gas import lines [11] ...........16

Figure 2.20 The EU import pipeline capacity [Source data: 1, 2] ........................17

Figure 2.21 The EU gas exchange, 2006 [Source data: 7] .............................19

Figure 3.1 Geographical outlook - Gas exporting states [27] ........................26

Figure 3.2 Eurasian single gas transmission network [30] .............................29 
Figure 3.3 Russian pipeline network and final export point [31] ......................30

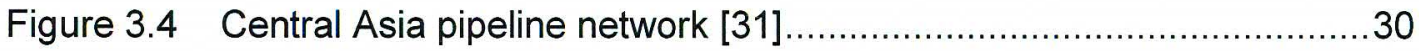

Figure 3.5 Russia gas balance [Source data: 28] ........................................ 32

Figure 3.6 Russian gas import profile [Source data: 28] ................................33

Figure 3.7 Russia gas export profile versus commitment [Source data: 11, 28] ...33

Figure 3.8 Regional look for the share of Russian gas in Europe

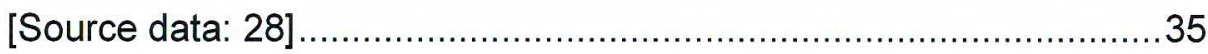

Figure 3.9 Gazprom's downstream activities in the EU [8] .............................. 37

Figure 3.10 Azerbaijan gas balance [Source data: 28] ...................................40

Figure 3.11 Kazakhstan gas balance [Source data: 28] ................................43

Figure 3.12 Uzbekistan gas balance [Source data: 28] ................................45

Figure 3.13 Turkmenistan gas balance [Source data: 28] .............................48

Figure 3.14 Turkmenistan gas export balance [Source data: 28] …...................49

Figure 3.15 Hydrocarbon infrastructure map of Iran [70] ...............................52

Figure 3.16 Iran gas balance [Source data: 28] ...........................................5

Figure 3.17 Hydrocarbon infrastructure map of Iraq [70] ..................................58

Figure 3.18 Iraq gas balance realization for last five years [Source data: 82] ........58

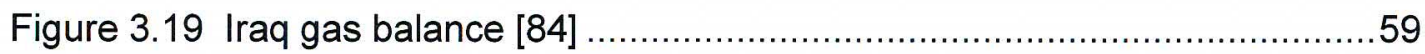

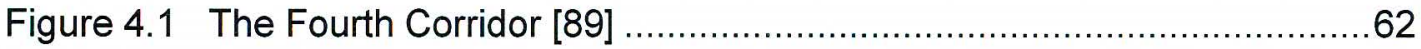

Figure 4.2 BOTAS's export/transit scenario for Turkey [87] ............................62

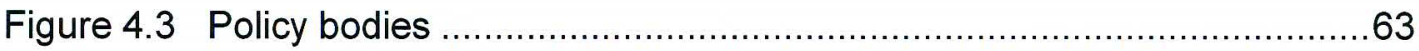

Figure 4.4 Turkey gas balance [Source data: 91, 92] ....................................68

Figure 4.5 Turkey gas transmission infrastructure [91] ................................ 70

Figure 4.6 Nabucco Pipeline [93] .......................................................... 73 


\section{LIST OF ABBREVIATIONS}

\begin{tabular}{|c|c|}
\hline ACG & Azeri-Charig-Ghunesli \\
\hline AGP & Arab Gas Pipeline \\
\hline $\mathrm{AIOC}$ & Azerbaijan International Operating Company \\
\hline $\mathrm{Bcm} / \mathrm{yr}$ & Billion cubic meter per year \\
\hline BOTAS & Turkish Pipeline Corporation \\
\hline BTE & Baku Tbilisi Erzurum \\
\hline CAC & Central Asian Center \\
\hline CEE & Central and Eastern Europe \\
\hline CERA & Cambridge Energy Research Associates \\
\hline EC & European Commission \\
\hline ECO & Economic Cooperation Organization \\
\hline EMRA & Energy Market Regulatory Authority \\
\hline EU & European Union \\
\hline HR & High Representative \\
\hline IEA & International Energy Agency \\
\hline KRG & KasRosGas \\
\hline LNG & Liquefied Natural Gas \\
\hline MENR & Ministry of Energy and Natural Resources \\
\hline MFA & Ministry of Foreign Affairs \\
\hline MoU & Memorandum of Understanding \\
\hline
\end{tabular}




\begin{tabular}{|c|c|}
\hline Mtoe/yr & Million tons of oil equivalent per year \\
\hline NWE & Northwest Europe \\
\hline PL & Pipeline \\
\hline PSA & Production Sharing Agreement \\
\hline SCP & South Caucasus Pipeline \\
\hline SG & Secretary General \\
\hline Sos & Security of Supply \\
\hline SWE & Southwest Europe \\
\hline $\mathrm{Tcm}$ & Trillion cubic meters \\
\hline TCP & TransCaspian Pipeline \\
\hline TGI & Turkey Greece Interconnector \\
\hline TPAO & Turkish Petroleum Corporation \\
\hline UGSS & Unified Gas supply System \\
\hline UNG & Uzbekneftegas \\
\hline UK & United Kingdom \\
\hline US & United States \\
\hline WEO & World Energy Outlook \\
\hline
\end{tabular}




\section{CHAPTER 1}

\section{INTRODUCTION}

Turkey with its geographic location holds a strategic role in natural gas between consumers and producers. In this respect, Turkey, since 1991, has sought to capitalize its advantageous position to be a natural gas (in general energy) transit country in the utilization of the sources of Central Asia and Middle East and to be transported to the European Union (EU) through the realization of the Fourth Corridor.

The Fourth Corridor can be defined as multiple pipelines series designed to transport the gas from the Central Asia and the Middle East through Turkey to the EU bypassing Russia as an alternative to the current three corridors coming from Russia, Norway, and North Africa, mainly Algeria as interpreted in the Green Paper released in the year of 2000 by the European Commission.

The Fourth Corridor includes two pipelines: small scale Turkey-Greece Interconnector connected to the Baku-Erzurum line to carry the Azeri gas to Greece that has been in operation since 2007; and the main artery pipeline called as Nabucco. The feature of these pipelines will give Turkey the chance of being major transit hub status, redirecting gas coming through regional export pipelines from different directions to the Nabucco.

The emergence of Turkey as a major gas transit hub will be dependent on several factors: the policies of consumer side, the EU; the export policies of producing countries in the region; and Turkey itself.

In this thesis these factors were argued through a process oriented approach to come to the conclusion that the Fourth Corridor ambition of Turkey especially due to the export policies of surrounding producers is a very weak chance.

Thesis is structured in the following way; 
Chapter 2 analyzes the gas supply/demand balance of the EU based on the official raw data of the European Commission and evaluates the EU's gas policy in terms of security of supply policy. It is argued that the gas import dependency will not be a critical issue for the future in terms of the volume of gap. However for the full functioning of the internal gas market, the EU has engaged in the diversification policy for an alternative supplier and route. The source in the Caspian region as well as the Gulf region (throughout the study Gulf region or Middle East indicates same producing states) has been in the portfolio of the EU and as a result Turkey, due to its geographical location, is considered as a corridor country.

Chapter 3 analyzes the producer countries and their export policies. Russia, Azerbaijan, Central Asian producers namely Kazakhstan, Uzbekistan and Turkmenistan and the Gulf producers Iran and Iraq are subjects to the chapter. Here the influence of Russia on the Central Asian states is an important element in the realpolitik of the region. In this chapter, one of the biggest uncertainties regarding the export volumes and directions in the region was clarified. Azerbaijan, due to its geography, made its direction clear to the west. But by the time the EU started to show interest towards the region, Russia by taking the advantage of Soviet legacy had made its policy very clear, holding its quasi-monopolistic position in transportation and supply as defined its energy agenda. Iran and Iraq, due to the internal and external difficulties, are not in the exporter row presently.

Chapter 4 evaluates Turkey's gas policy and its ambition of being a major transit gas hub. This realization will significantly depend on export policies of producer countries and the internal gas demand/supply balance of Turkey. The analysis shows that Turkey will face a deficit starting in the year of 2015 and the volume of gas that producers will transit to Europe via Turkey will be well below than what Turkey expects. The above factors and Turkey's decision (somewhat necessity) to secure its demand out of transit gas will negatively affect the realization of major pipeline Nabucco.

Therefore, the thesis concludes that Turkey may only be a small scale transit gas hub. This study does not see the possibility of Turkey being a large scale gas transit hub country in the next decade. 


\section{CHAPTER 2}

\section{THE EUROPEAN UNION GAS DEMAND AND SUPPLY: SECURITY OF SUPPLY}

\subsection{Demand}

Gas has become the fuel of choice throughout Europe, increasing its market share in all sectors in all Member States. In 2007, 440.27 Mtoe (488.7 Bcm) gas was consumed, a drop of $1.6 \%$ compared to consumption of $446.9 \mathrm{Mtoe}(496.6 \mathrm{Bcm})$ in 2006. Natural gas accounted for approximately $24.4 \%$ of total EU-27 primary energy demand in 2007 compared to $18 \%$ in 1990 and less than $2 \%$ in 1960.

The EU demand for gas is expected to increase considerably over the coming twenty years. In order to take timely actions in terms of supply security, several Institutions such as WEO/IEA and EUROGAS for the EU-30 [1] and the EU Commission (EC) for the EU-27 [2] have been working on the gas balance scenarios (Figure 2.1) for the future of EU gas demand. It may be depicted that as the models run by Institutions and the EC are adjusted to account for the developments such as expectation in price chance, diversification in the fuel type, each new forecast harmoniously states that the EU's gas demand will decrease. The last forecast of CERA for the EU-27 [3] also indicates the decrease in demand. It can also be added that the differences between forecasts are mainly due to assumptions about the long term power generation mix. So, the consumption in the power generation is the most uncertain element in the gas demand forecasts.

According to the base scenario, primary energy consumption was expected to grow at an annual rate of $0.6 \%$. The share of natural gas in the energy mix will be increasing from $24.4 \%$ in 2007 to $27.4 \%$ in 2030 (Figure 2.2 and 2.3) with the highest growth rate at $1.1 \%$ per year together with renewable. Under such a forecast an additional $106 \mathrm{Mtoe} / \mathrm{yr}(117.7 \mathrm{Bcm} / \mathrm{yr})$ of natural gas to meet the demand has to be supplied to Europe in 2030 compared to consumption of 440 Mtoe/yr (488.8 $\mathrm{Bcm} / \mathrm{yr}$ ) in 2007. 


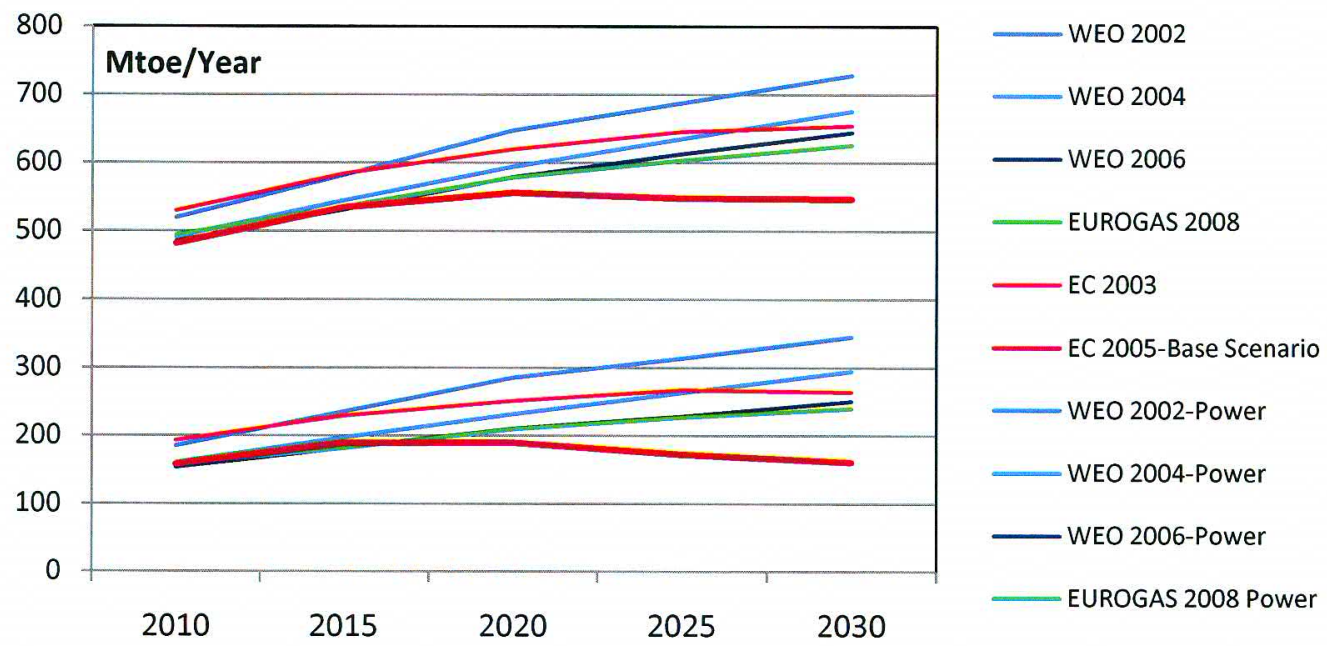

Figure 2.1 Comparison: Institutional projections for the EU gas demand [1, 2]

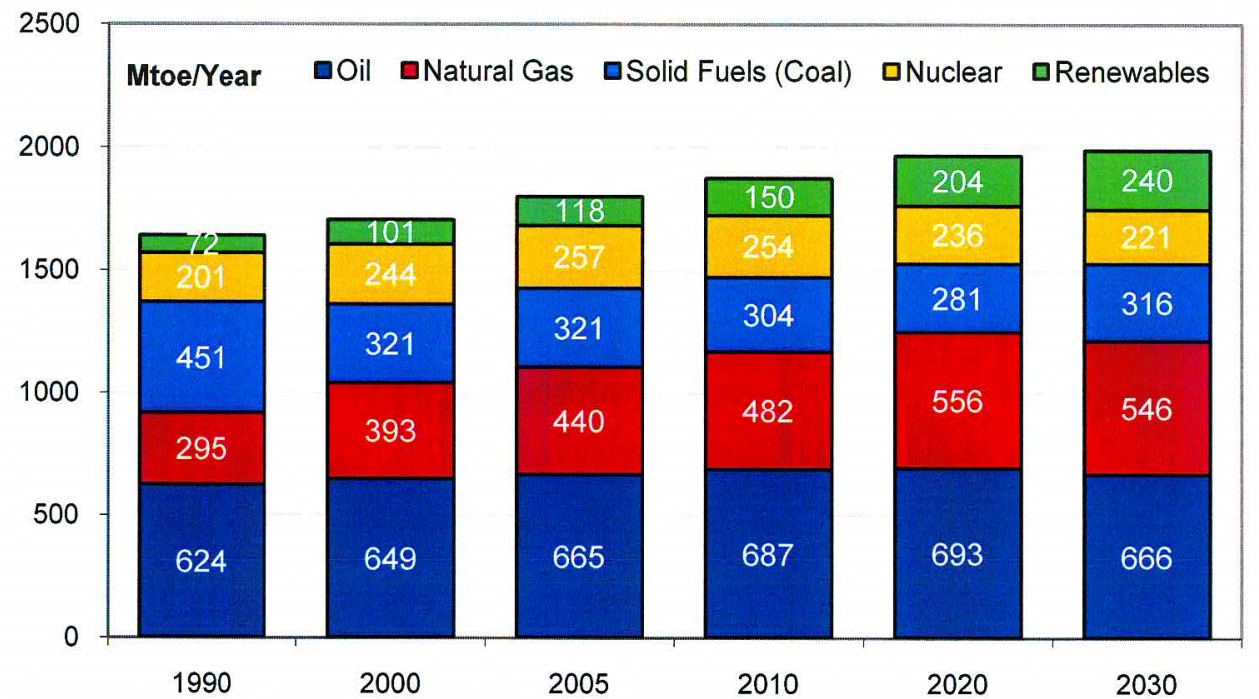

Figure 2.2 The EU primary energy demand, Mtoe/yr [Source data: 2]

At the Member State level, the gas use varies from country to country depending on policies and priorities of that country (Figure 2.4). For example $40 \%$ of France's energy consumption is nuclear energy while gas only represents $13-14 \%$ of primary energy consumption. In Germany, gas represents $25 \%$ and with coal constitutes almost $50 \%$. By contrast, in the UK, share of gas increases, with the liberalization process started in the early 1990s, from 30\% in 1995 to $38 \%$ in 2005 at the expense of coal. But, situation changes in the new Member States. The dependency in these 
States is much higher than that in the west and will be slightly higher due to the adaptation into internal environmental regulation of the EU.

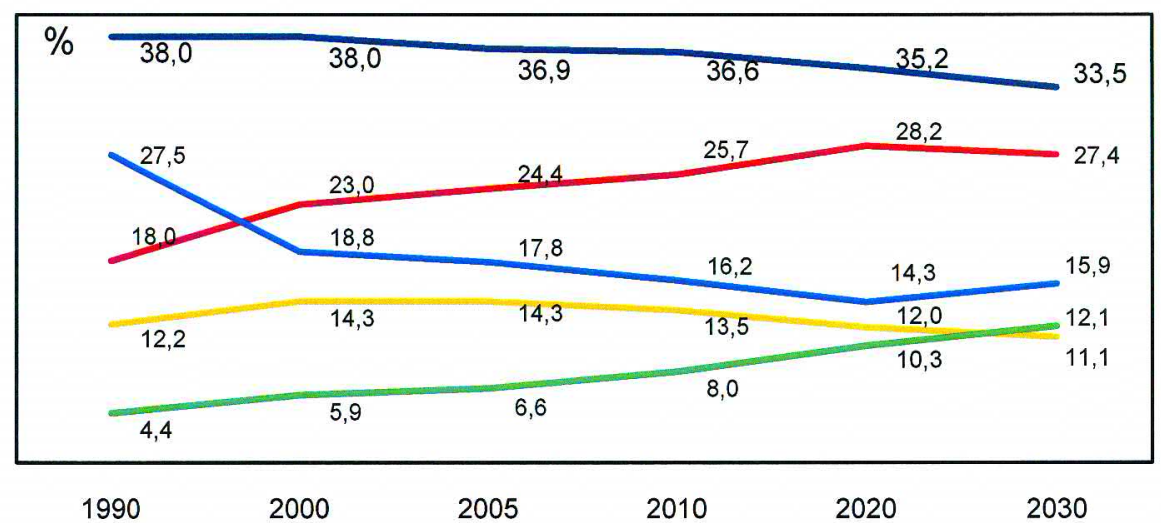

Figure 2.3 The EU primary energy demand, \% [Source data: 2]

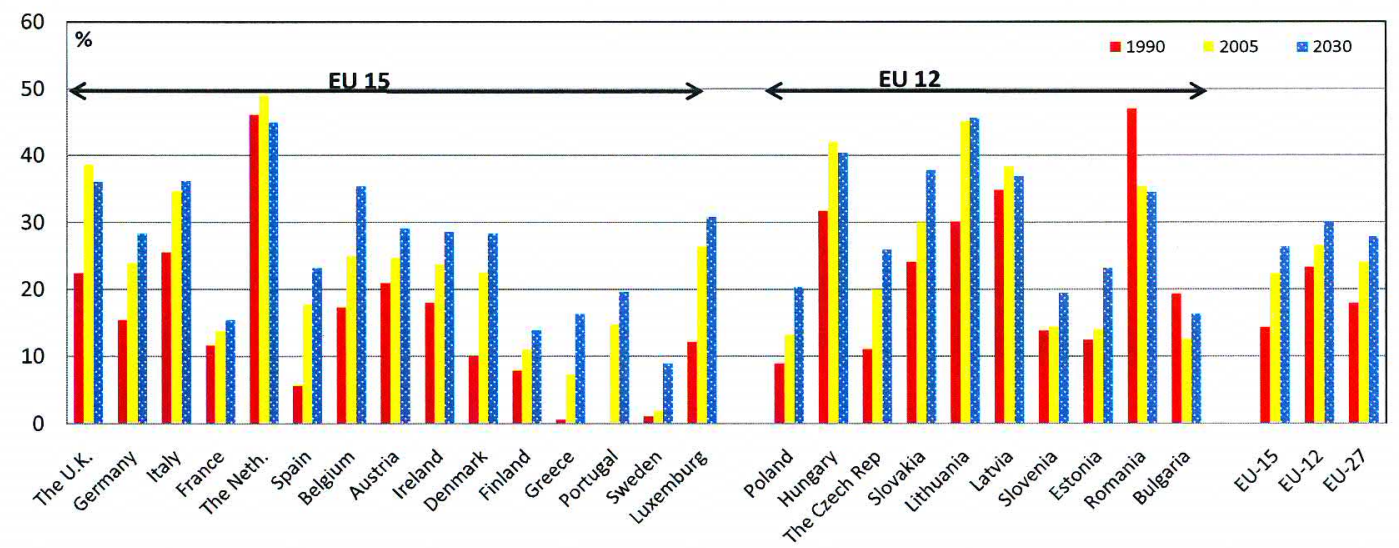

Figure 2.4 The EU share of natural gas in primary energy demand at the Member State basis, \% [Source data: 2]

One of the main reasons for the substantial increase in the use of natural gas is a result of investment in the power generation sector. Improved fuel-conversion efficiencies, shorter construction times, lower capital costs and most importantly measures to clean up the environment- driven partly by the Kyoto protocol, due to the low specific carbon emissions compared to other fuels, coal and oil, made gas the fuel of choice for the new plants.

Today, $29 \%$ of the total gas consumption is associated with the power generation compared to the $18 \%$ in 1990 . According to the base scenario, this increasing trend 
is supposed to continue up to $34 \%$ by 2020 then it is anticipated to decrease to $29 \%$ by 2030 (Figure 2.5 B). The decrease will be mainly thanks to return to clean coal, nuclear, and renewable. However, the increasing dependence on gas in power generation raises an issue with regard to the increasing interdependence between two sectors. Dependence of power generation on imported gas might create a domino effect on power sector in case of supply shortage [4].

Lately, in order to see the effects of increasing oil prices, the European Commission conducted two alternative price scenarios. Scenarios take into account two different price levels: World medium gas and soaring oil prices; and world soaring gas and oil prices [5]. It is observed that rising gas prices due to higher oil price have led to a lowering of gas demand expectations (Figure $2.5 \mathrm{~A}, \mathrm{~B}$ ).

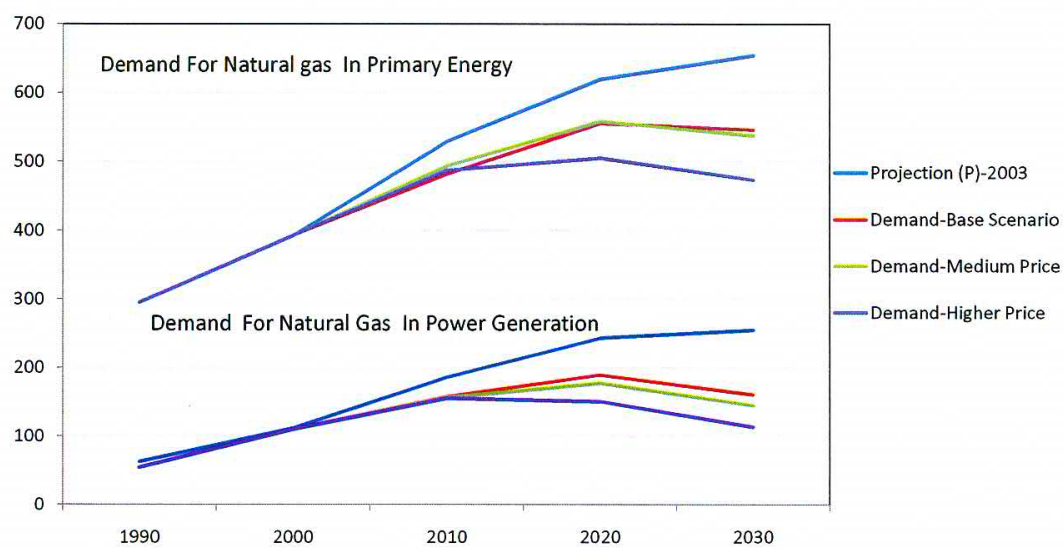

(A)

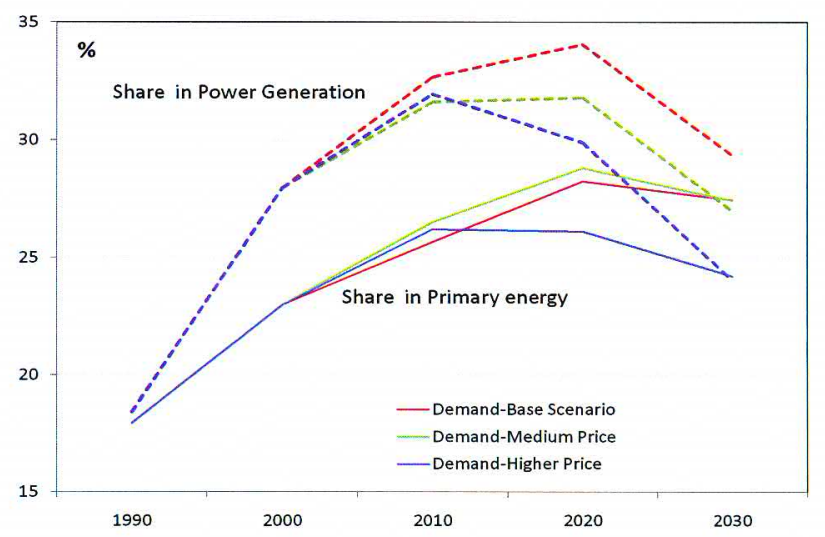

(B)

Figure 2.5 The EU projections for different gas prices A) Mtoe/yr, B) \% [Source data: 5] 
This result also means that inadequate knowledge about the future gas price causes an uncertainty about future EU gas demand.

As a result, by taking into consideration the price-demand relations and the EU's strategy in balanced diversification of fuel types along with the roadmap proposed by the European Commission's paper "An Energy Policy for Europe" [6] released on January 10,2007 for increasing the share of renewable in primary energy up to $20 \%$ and reducing $\mathrm{CO} 2$ emission by $20 \%$ by 2020 , further shrinkage in the demand may also occur, especially in power generation.

Demand (Figure 2.6) is concentrated in 6 largest gas markets. In 2006, 52.3\% of demand was consumed in three countries of Western Europe: The U.K., Germany, and Italy. This percentage reaches $76 \%$ with the inclusion of France, The Netherlands, and Spain. The map in Figure 2.6 shows the level of demand of the States (color intensity increases as demand gets higher).

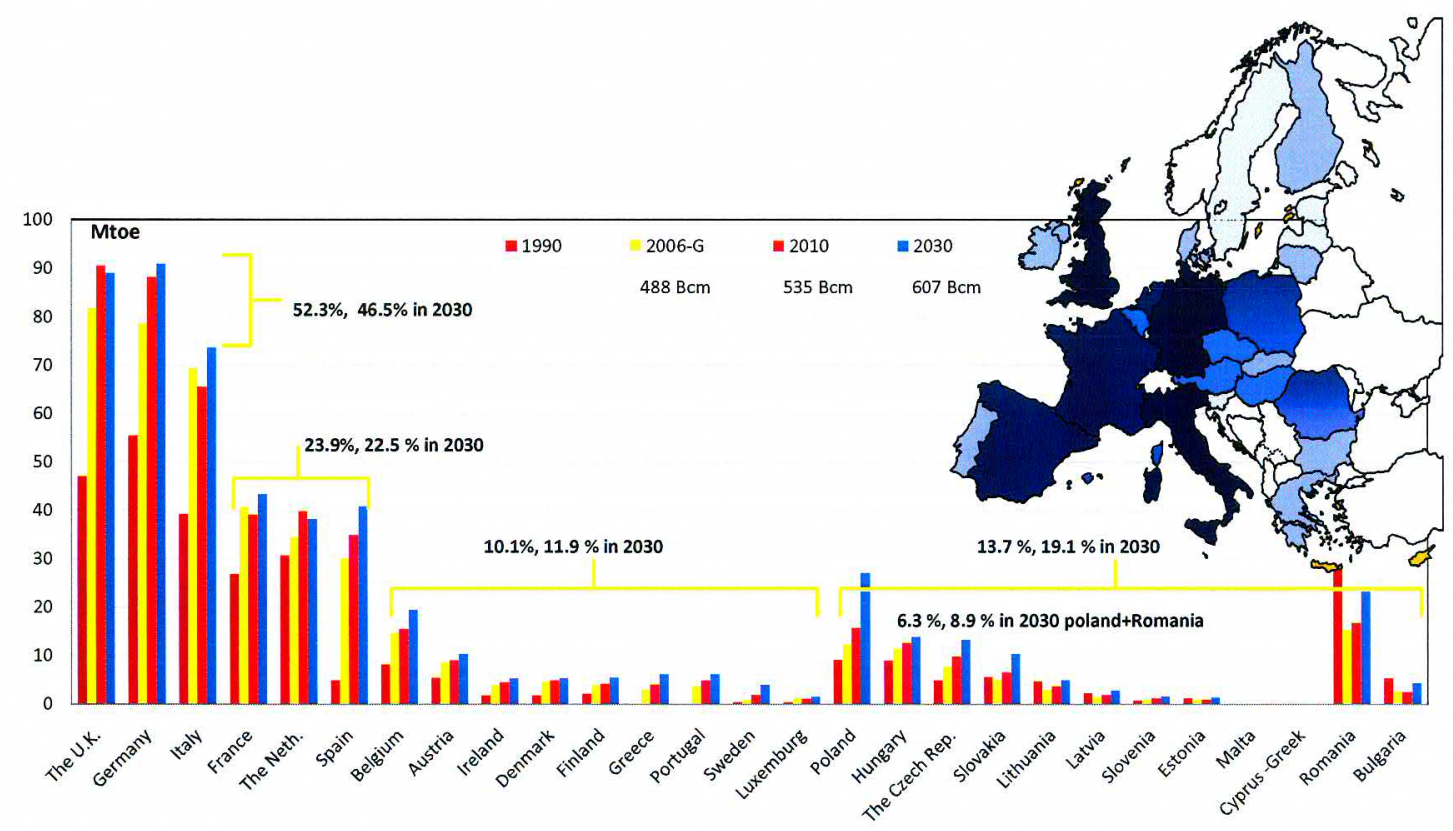

Figure 2.6 The EU projection for natural gas demands of the Member States [Source data: 


\subsection{Supply}

\subsubsection{Indigenous Reserves and Supply}

There are a number of EU States that have access to considerable domestic reserves (Figure 2.7). The most significant are the U.K. and the Netherlands. As of the end of 2007, the remaining reserve value is around $3 \mathrm{Tcm}$ [7].

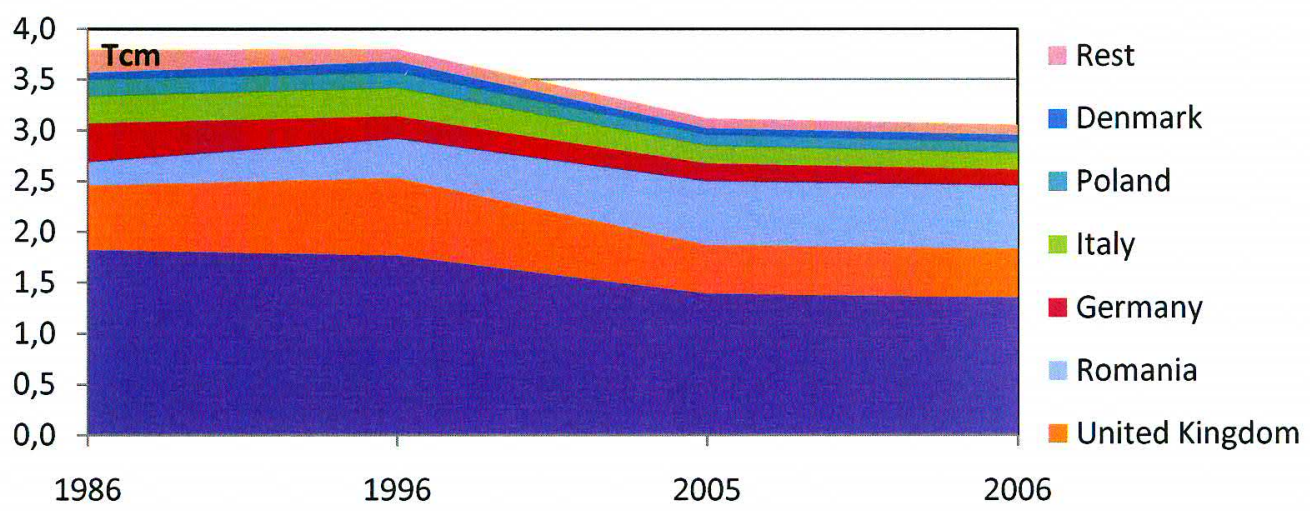

Figure 2.7 The EU indigenous reserves profile [Source data: 7]

European gas is produced mainly by the UK and the Netherlands. Also, Denmark, Germany, Italy and Romania produce significant quantities (Figure 2.8, 2.9). The EU States in total produced $191 \mathrm{Mtoe}(212 \mathrm{Bcm})$ in 2005, $184.4 \mathrm{Mtoe}(204.9 \mathrm{Bcm})$ in 2006 and 172.7 Mtoe (191.9 Bcm) in 2007, corresponding to the $42.3 \%, 41.26 \%$, and $39.3 \%$ in sufficiency, respectively (Figure 2.8 ).

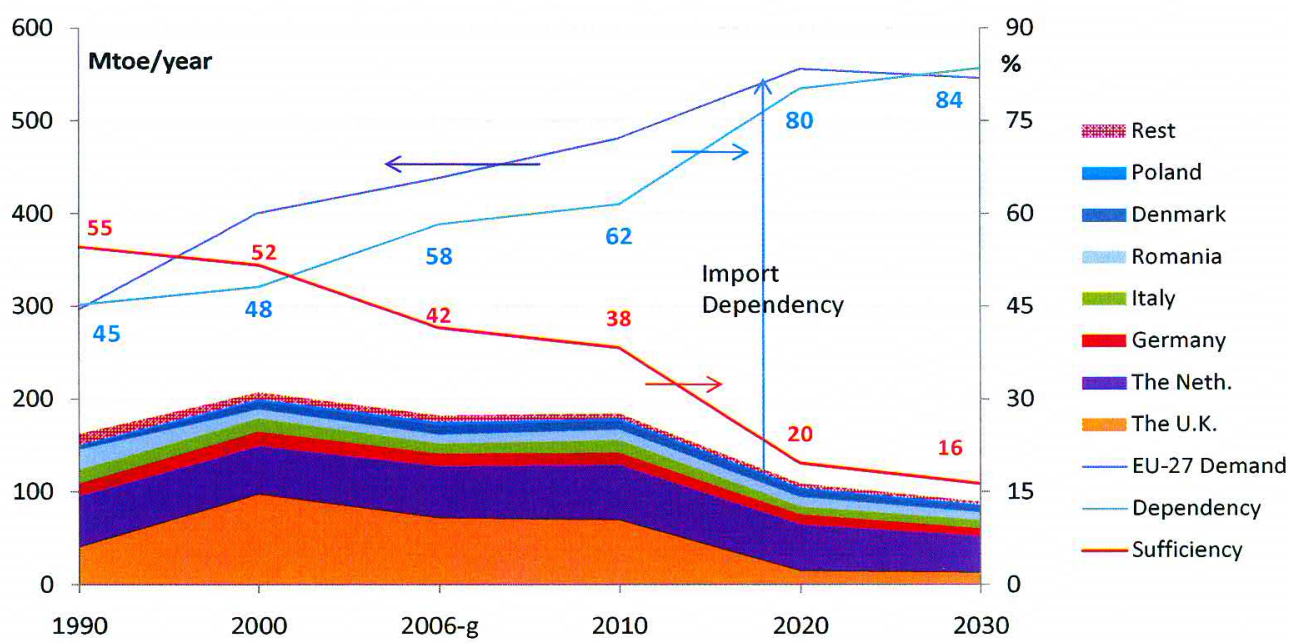

Figure 2.8 The EU indigenous production [Source data: 2] 
This implies that there is a decline in domestic production and this decline will accelerate after 2010 due mainly to sharp falls in the North Sea offshore production of the UK side (Figure 2.9). It is forecasted that the indigenous European production will likely be limited to $89 \mathrm{Mtoe} / \mathrm{yr}(99 \mathrm{Bcm} / \mathrm{yr}$ ) in 2030. This production will represent $16 \%$ of the EU gas requirement if there will not be any reserve replacement to lessen the sharp drop (Figure 2.8).

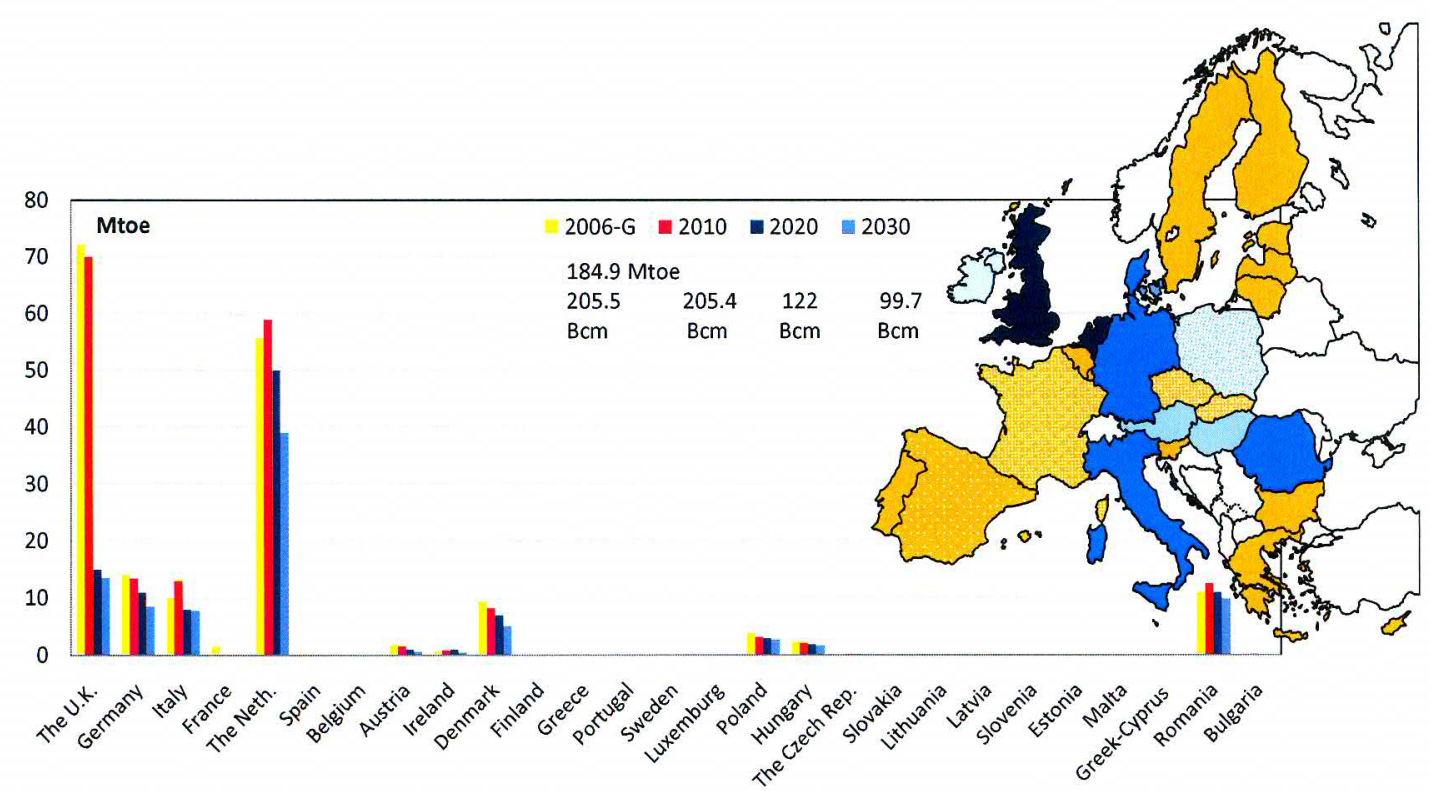

Figure 2.9 The EU projection for domestic supply profile of the Member States [Source data: 2]

\subsubsection{Import}

The EU is already slightly over $58 \%$ dependent on externally imported natural gas with 275.56 Mtoe $(306.17 \mathrm{Bcm})$ according to 2006 figures. In the EU, all states except 2 self-sufficient states, the Netherlands and Denmark, depend on import. The other self sufficient state, the UK starting from 2006, moved from its present position of net exporter to become a net importer of gas.

The need for imported gas (Figure 2.10) is mainly met from Russia, Norway and Algeria via pipeline corresponding presently to $84 \%$ of import to the EU with 229.03 Mtoe $(254.47 \mathrm{Bcm})$ and to the lesser extent from North, West Africa and Gulf via 
LNG corresponding to $16 \%$ with 46,53 Mtoe $(51,69 \mathrm{Bcm})$ according to the 2006 realization (Figure 2.11). 2007 realization with 271.54 Mtoe $(301.81 \mathrm{Bcm})$ is very close with low decline to the figures of 2006. This is referred to the decrease in consumption in the EU due to warm weather conditions.

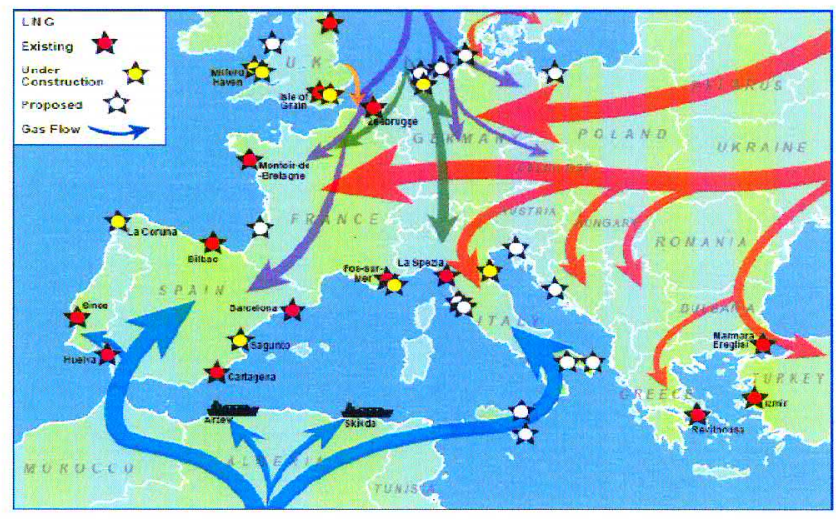

Figure 2.10 The EU main natural gas import routes [8]

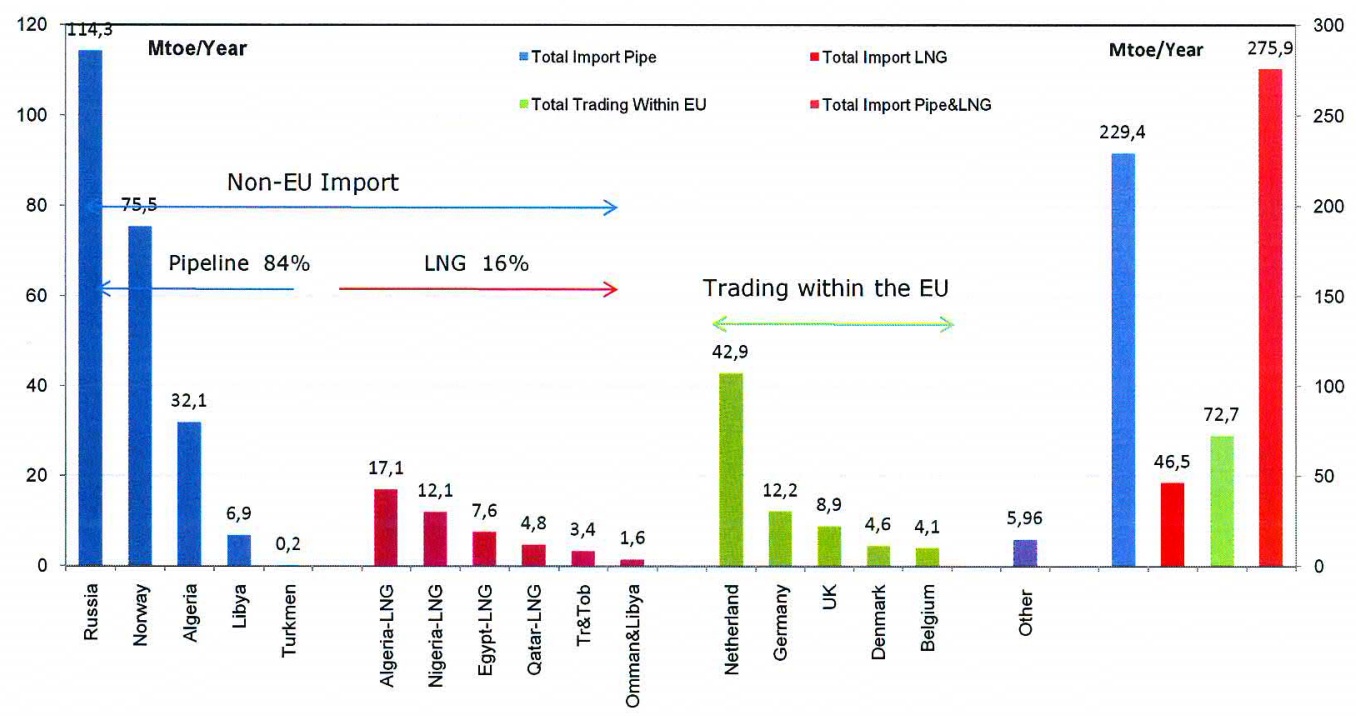

Figure 2.11 The EU gas import origin, 2006 [Source data: 7] 


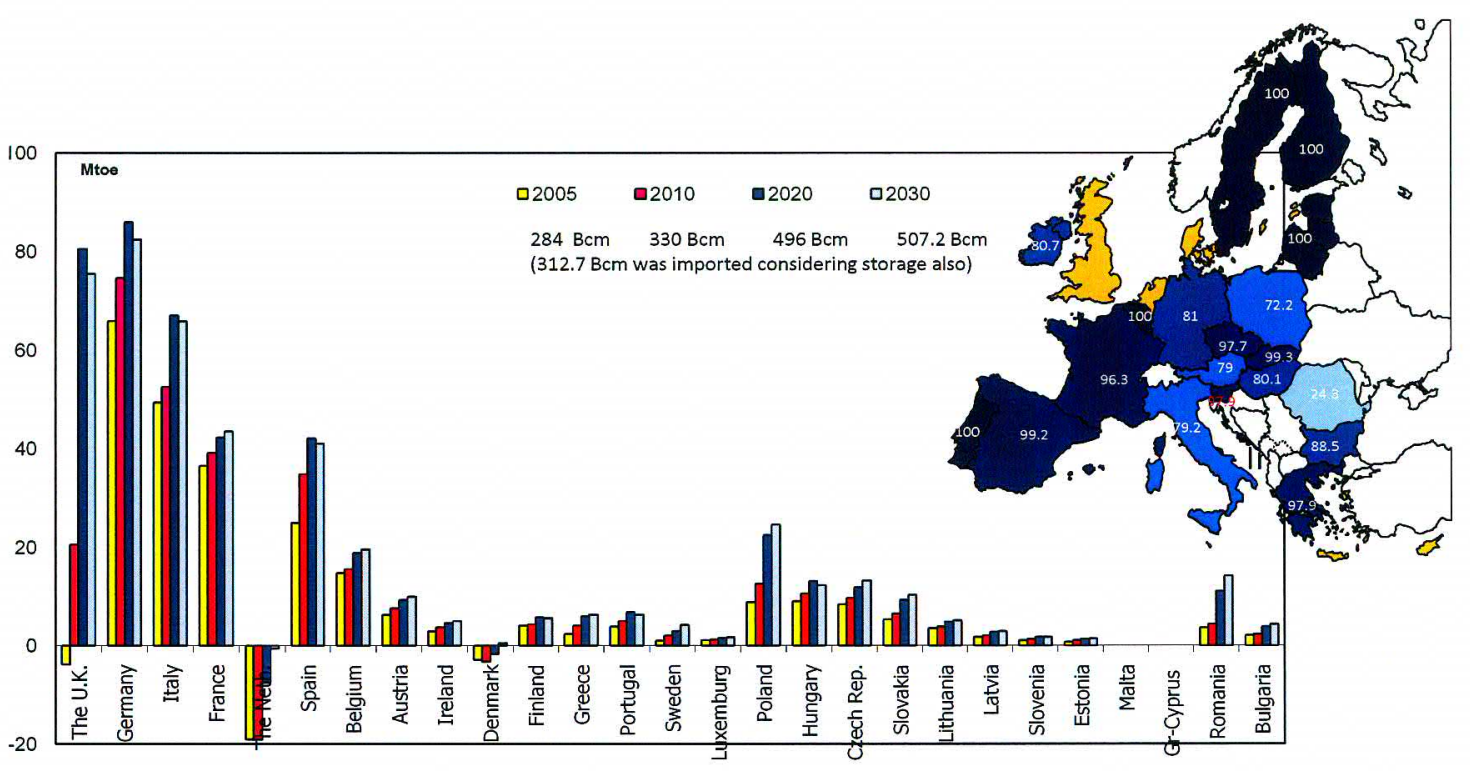

Figure 2.12 The EU projection for natural gas import of the Member States [Source data: 2]

Within this picture in 2006 , with $25 \%$ share in the EU total gas consumption and $41 \%$ share in externally imported gas in 2006 , Russia presently is the leading country (Figure 2.13) [7].

Total consumption

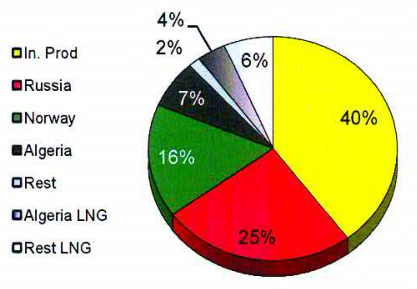

Import

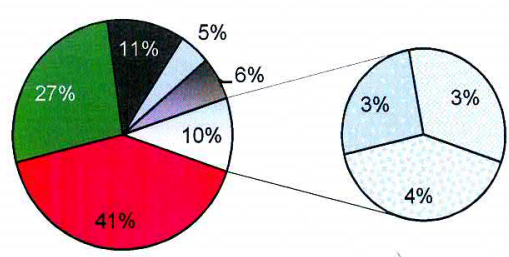

84\% PL (Pipeline)

Norway

- Algeria-PI

口Rest-PL

- AIgeria-LNG

DNigeria-LNG 16\% LNG

DEgypt-LNG Spain and Italy are the

口Rest-LNG

Figure 2.13 The EU demand balance \%, 2006 [Source data: 7]

The Figure 2.12 shows import projections for the Member States. As observed, import is concentrated in the largest gas markets (Figure 2.6). The map in Figure 2.12 shows the level of import dependence of the States in terms of percentage (color intensity increases as percentage gets higher). Except two self-sufficient Members, The Netherlands, Denmark (until 2005, the UK was also self-sufficient), 
and Romania with the import dependency of $35 \%$ the rest 23 States are dependent on imports for more than $70 \%$ of their gas demand.

For the level of import dependency, geography (Figure 2.14) and infrastructure (Figure 2.16) are the determining criteria. The import dependency can be analyzed in terms of source, transit and facility dependency for risk analysis.

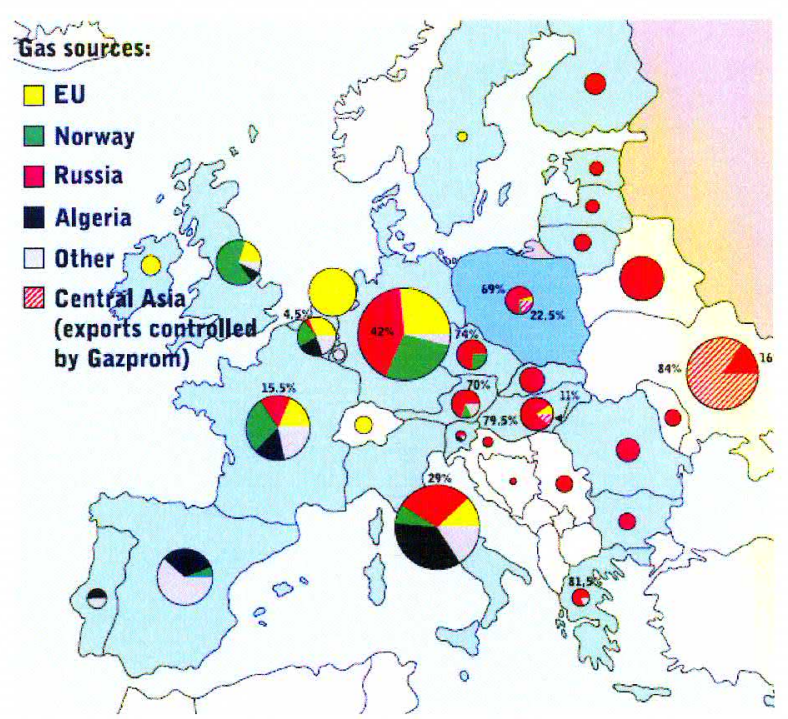

Figure 2.14 The EU regional import dependency profile [9]

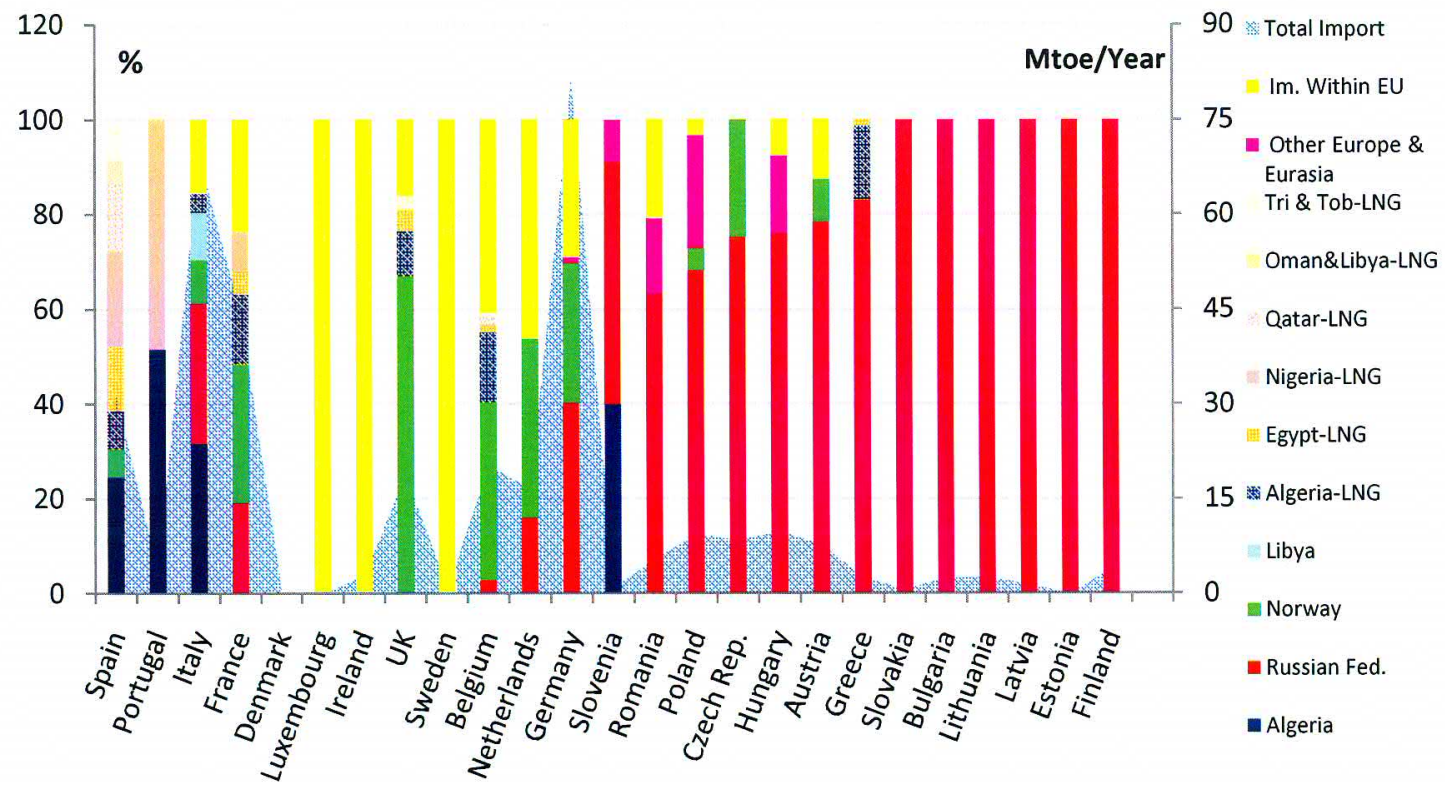

Figure 2.15 The EU suppliers share in imports, 2006 [Source data: 7] 
Taking into consideration Figure 2.14 and Figure 2.15, the EU can be divided naturally into three distinct regions in terms of source of imports and level of integration of gas transmission infrastructure (Figure 2.16).

- Southwestern Europe (SWE): It is dependent on mainly Algeria. However, well diversified LNG imports lessen the single supplier burden.

- Northwestern Europe (NWE): It is best placed in terms of diversity of supplies. Among well diversifies internal and external suppliers, Norway is the leading external supplier

- Central and Eastern Europe, including Baltic States (CEE): Land-locked region is poorly diversified and dominated by Russian gas.

Here while SWE and NWE represent the EU-15, CEE represents the newly accepted last 12 Member States.

The above division indicates that the EU faces an asymmetric external source dependency (Table 2.1) [7] and a weakly connected infrastructure (Figure 2.16) within and between regions. For instance, while SWE and NWE States have well diversified supply origins and the share of single supplier barely reaches around $40 \%$ in portfolio (just in Germany and Portugal), CEE States depend on mainly one single supplier. This supplier, due to its historical links and its geographical location, is Russia.

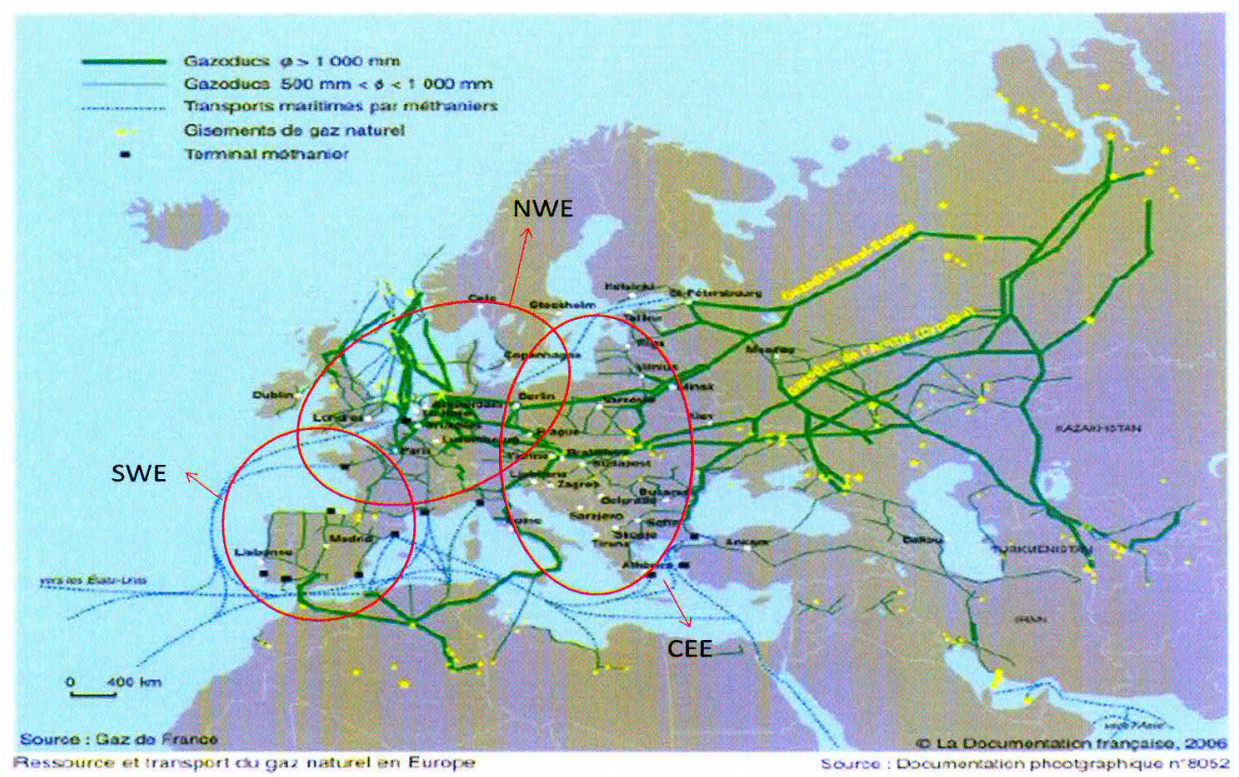

Figure 2.16 The EU regional division [10] 
Gas markets are much smaller in CEE region on the contrary to NWE and SWE regions (Figure 2.6). However, CEE in general will be the most vulnerable region because of inflexibility in supply since CEE, due to its limited infrastructure, will face a difficulty in connection to very liquid region NWE in any disruption of gas.

Table 2.1 The EU regional import dependency [Source data: 7]

\begin{tabular}{|l|c|c|c|}
\hline SUPPLY ORIGIN \%- 2006 & EU-27 & EU-15 & NEW MEMBERS \\
\hline Indigenous Production & 40 & 41 & 30 \\
\hline Russia & 25 & 19 & 64 \\
\hline Norway & 16 & 18 & 4 \\
\hline Algeria PL\&LNG & 11 & 12 & 1 \\
\hline LNG (except Algeria) & 6 & 7 & 0 \\
\hline Rest Pipeline (PL) & 3 & 3 & 0 \\
\hline
\end{tabular}

Knowing the reality, the Commission since 2000, for the successful opening of competitive internal energy market has been suggesting a completion of interconnections between national networks for the continuous flow throughout the $E U$. For that reason integrating state to state and region to region infrastructure in all over Europe is essential. Otherwise in-sufficient intra-EU gas network becomes a major bottleneck for the expansion of gas supplies from outside the EU since it may not be possible to deliver the supply from surplus gas in well diversified region to the region/states in need.

The projection in the base scenario shows that Import dependency in EU is expected to increase to $61.6 \%$ in 2010, $80.3 \%$ in 2020 and $83.6 \%$ in 2030 (Figure 2.8). Namely, the import volumes needed to meet the demand will grow from 329.7 $\mathrm{Bcm}$ in 2010 to $495.9 \mathrm{Bcm}$ in 2020 and to $507.2 \mathrm{Bcm}$ in 2030 annually (Table 2.2). 


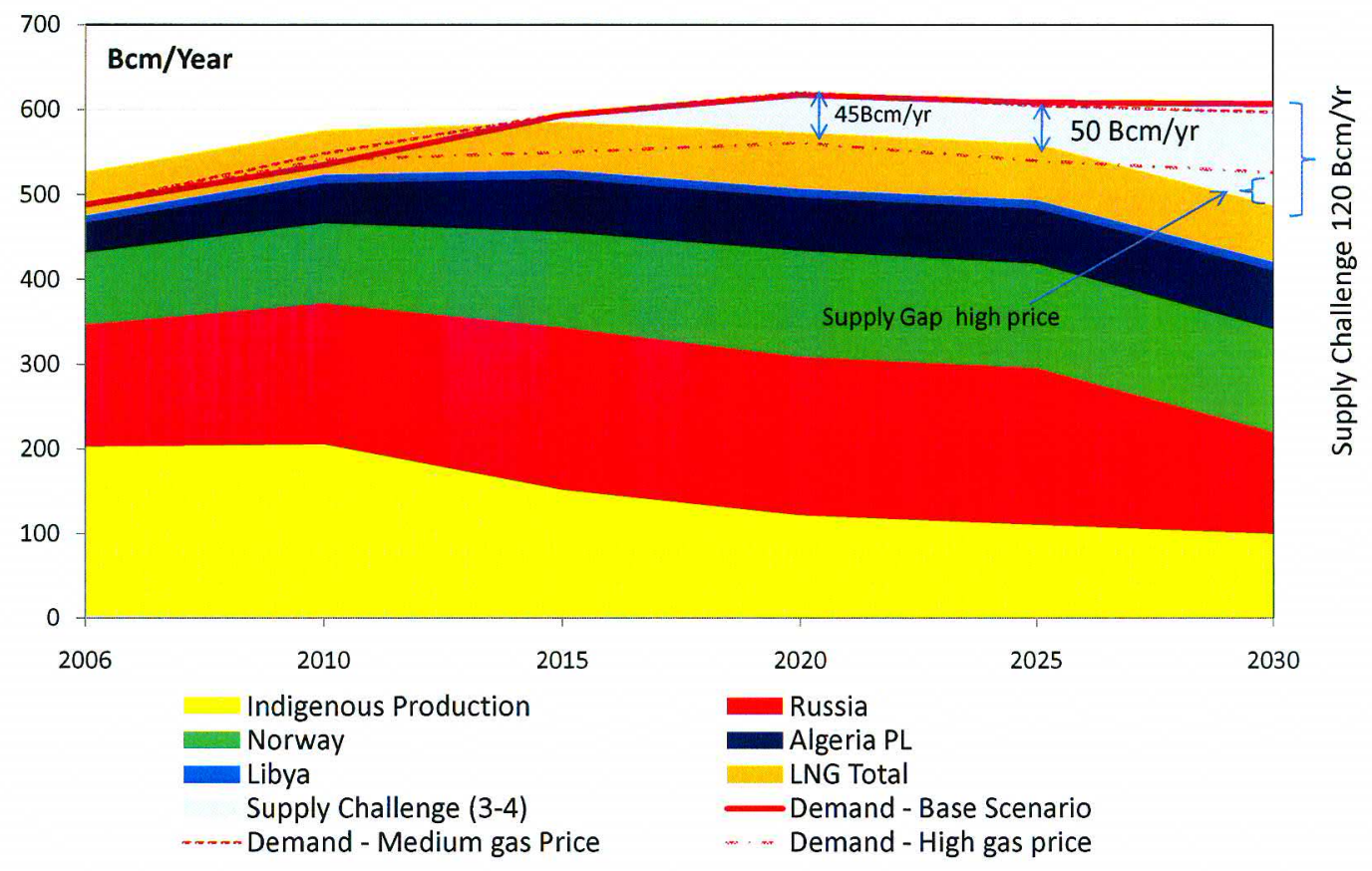

Figure 2.17 The EU supply challenges in natural gas demand, $\mathrm{Bcm} / \mathrm{yr}$ [Source data: 2,12 ]

Of this dependency, $370 \mathrm{Bcm}$ in 2010 and $451 \mathrm{Bcm}$ in 2020 and $387 \mathrm{Bcm}$ in 2030 was secured under long-term contracts with duration of up to 20 to 30 years (Figure 17, Table 2.2) [12].

Table 2.2 The EU supply challenge [Source data: 2, 12]

\begin{tabular}{|r|l|r|r|r|r|r|r|}
\hline & Bcm/yr & 2006 & 2010 & 2015 & 2020 & 2025 & 2030 \\
\hline 1 & Demand & 487,7 & 535,1 & 593,4 & 617,5 & 608,5 & 606,9 \\
\hline 2 & Indigenous Production & 202,9 & 205,4 & 151,0 & 121,7 & 110,5 & 99,8 \\
\hline 3 & Import (1-2) & 284,9 & 329,7 & 441,5 & 495,8 & 498,0 & 507,2 \\
\hline & Import dependency & 58,4 & 61,6 & 74,4 & 80,3 & 81,8 & 83,6 \\
\hline & & & & & & & \\
\hline 4 & Import Committed & 323,3 & 370,0 & 433,0 & 451,0 & 449,0 & 387,0 \\
\hline & Russia & 143,9 & 166,0 & 191,0 & 187,0 & 185,0 & 120,0 \\
\hline & Norway & 84,4 & 95,0 & 113,0 & 125,0 & 123,0 & 122,0 \\
\hline & Algeria PL & 35,6 & 47,0 & 63,0 & 63,0 & 65,0 & 69,0 \\
\hline & Libya & 7,8 & 10,0 & 10,0 & 10,0 & 10,0 & 10,0 \\
\hline & LNG Total & 51,7 & 52,0 & 56,0 & 66,0 & 66,0 & 66,0 \\
\hline & & & & & & & \\
\hline & 0,0 & 0,0 & 8,6 & 44,8 & 49,0 & 120,0 \\
\hline
\end{tabular}

This will leave a deficit (supply challenge or un-contracted volume) of $8.6 \mathrm{Bcm}$ starting in 2015, $45 \mathrm{Bcm}$ in 2020 and $120 \mathrm{Bcm}$ in 2030 (Table 2.2) to be filled 
through new agreements with current and/or potential new suppliers. These uncontracted volumes will correspond to $9 \%$ in 2020 and $24 \%$ in 2030 (Figure 2.18).
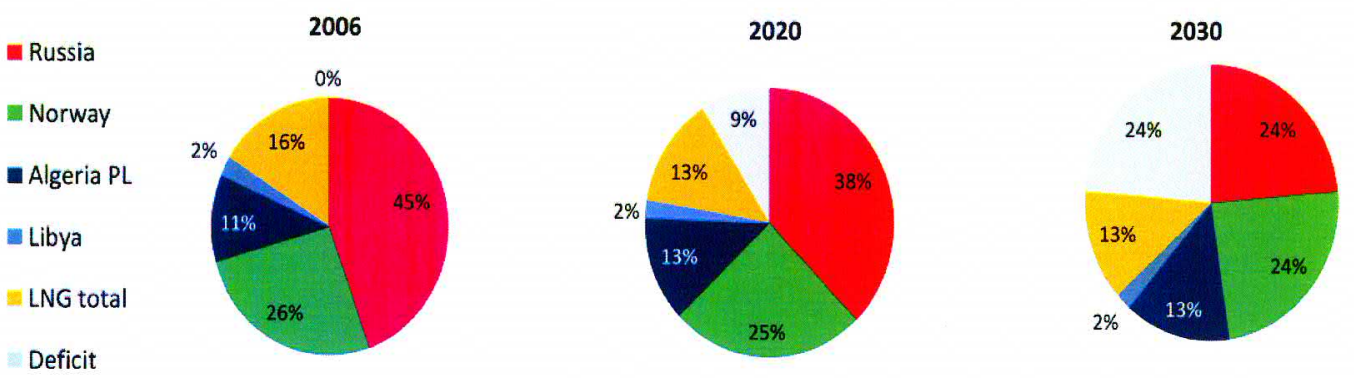

Figure 2.18 The EU supply challenge in natural gas demand, \% [Source data: 2,12 ]

The most likely sources (Figure 2.19) to meet the relatively low import deficit (uncontracted volume) are: first, the existing suppliers that the EU has relied for many years. These are mainly Russia, Norway, and North African Countries Algeria, Libya and Egypt with new additional transportation routes and LNG infrastructures; second, new potential suppliers, from Africa and Central Asia, the Middle East, provided some political constraints are removed and necessary infrastructure related to routes is developed.

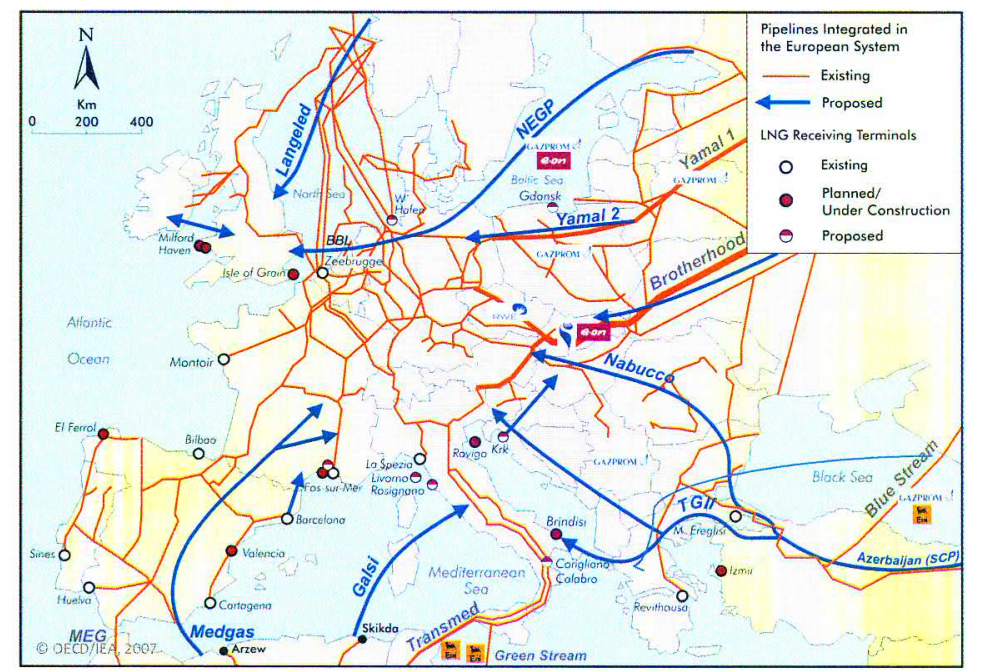

Figure 2.19 The EU operational and proposed main gas import lines [11] 
This gap (uncontracted volume) can be easily filled with nearby North African producer countries and Norway, where recent gas discoveries may result in production increases in the medium term, with the existing pipeline and LNG infrastructure or a new one with medium size investment (Table 2.3, Figure 2.20) [1].

Table 2.3 The EU import pipeline capacity [Source data: 1]

\begin{tabular}{|l|c|c|c|c|}
\hline & $\mathbf{2 0 0 6}$ & $\mathbf{2 0 1 0}$ & $\mathbf{2 0 2 0}$ & $\mathbf{2 0 3 0}$ \\
\hline Russia & 191 & 212 & 212 & 212 \\
\hline Norway & 87 & 119 & 119 & 119 \\
\hline Algeria & 36,5 & 53 & 81 & 83 \\
\hline Libya & 8 & 8 & 16 & 24 \\
\hline Turkey-Greece & 0 & 8 & 12 & 12 \\
\hline TOTAL Existing+Expansion & $\mathbf{3 2 2 , 5}$ & $\mathbf{4 0 0}$ & $\mathbf{4 4 0}$ & $\mathbf{4 5 0}$ \\
\hline \hline North Stream-Russia Planned & 0 & 0 & 55 & 55 \\
\hline TOTAL planned & $\mathbf{0}$ & $\mathbf{0}$ & $\mathbf{5 5}$ & $\mathbf{5 5}$ \\
\hline
\end{tabular}

\begin{tabular}{|l|c|c|c|c|}
\hline South Stream-Russia Potential & 0 & 0 & 30 & 30 \\
\hline Nabucco - Potential & 0 & 0 & 30 & 30 \\
\hline TOTAL Potential & 0 & 0 & 60 & 60 \\
\hline \hline
\end{tabular}

\begin{tabular}{|l|c|c|c|c|}
\hline GRAND TOTAL & 322,5 & 400 & 555 & 565 \\
\hline
\end{tabular}

\begin{tabular}{|l|l|l|l|l|}
\hline Import & 284,9 & 329,7 & 495,8 & 507,2 \\
\hline Demand & 487,7 & 535,1 & 617,5 & 606,9 \\
\hline
\end{tabular}

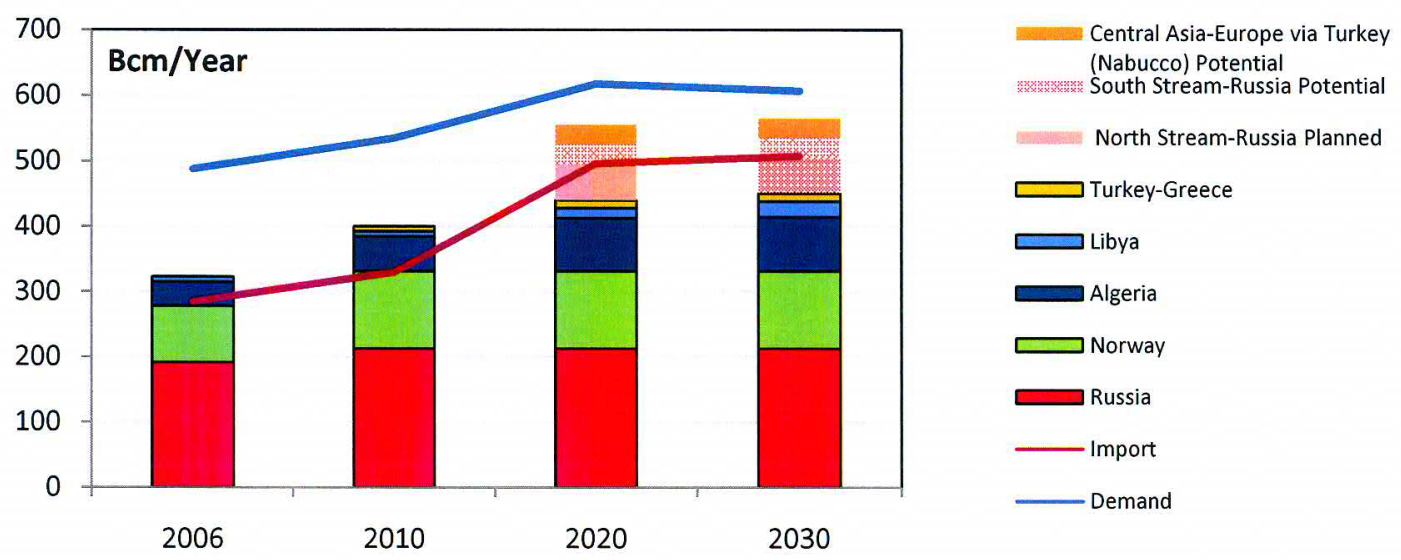

Figure 2.20 The EU import pipeline capacity [Source data: 1, 2] 
Table 2.4 LNG export capacity of neighbor producers to the EU [Source data: 1]

\begin{tabular}{|c|c|c|c|c|}
\hline Bcm/yr LNG & $\mathbf{2 0 0 7}$ & $\mathbf{2 0 1 0}$ & $\mathbf{2 0 2 0}$ & $\mathbf{2 0 3 0}$ \\
\hline Norway & 1 & 6 & 6 & 10 \\
\hline Algeria & 27,5 & 38 & 38 & 43 \\
\hline Libya & 1 & 4 & 9 & 14 \\
\hline Egypt & 16,5 & 23,4 & 28,2 & 28,2 \\
\hline TOTAL & 46 & $\mathbf{7 1 , 4}$ & $\mathbf{8 1 , 2}$ & $\mathbf{9 5 , 2}$ \\
\hline
\end{tabular}

LNG to improve the supply flexibility will increase its size in Europe from $16 \%$ in 2006 to $20 \%$ in 2030 . According to 2006 figures, The EU has 12 LNG regasification terminals in operation with $74.8 \mathrm{Bcm} / \mathrm{yr}$ capacities. With the inclusion of another 12 terminals that are under construction with the $72.4 \mathrm{Bcm} / \mathrm{yr}$ capacities, the total LNG regasification capacity of the EU will reach $147 \mathrm{Bcm} / \mathrm{yr}$ [13] around 2010. In the future, LNG will have an essential role in adding gas import capacity.

Considering the magnitudes of long-term contracted gas volumes, deficit to be secured (Table 2.2), and the export capacities of suppliers for the future (Table 2.3, and 2.4) it may be said that a) Natural gas will remain largely a pipeline market in the EU despite growing importance of LNG, b) current suppliers will have the capacity to close the gap, c) however, the EU in order to increase the competition in its internal market and to meet the short to medium term disruptions will give preference to the source diversification in addition to the route diversification, d) Russia will remain one of the biggest suppliers in the picture with Norway but its importance will decline as the EU looks for alternatives.

But just to meet the import requirement does not mean much if it is not possible to facilitate continuous flow throughout the EU. For that reason, the internal European gas infrastructure needs to be adapted to all the regions mainly connecting CEE region, Italy and Spain into the rest of the EU.

\subsection{Hub Concept}

Closer look into the Figure 2.11 reveals that while the majority of gas is traded under long-term contracts, a small amount of domestic and external gas is traded short term and on the spot market within the EU at several gas market centers (Trading Hub) (Figure 2.21). 
Hub concept is a rather recent development in the EU with the introduction of market liberalization. Two types [5] of hubs exist: a) Transit hub which is physical gas transfer point where several pipelines are connected to a facility that permits the redirecting of gas volumes of the owners from one pipeline to another. Transit hub does not give the right of title transfer; b) Trading hub which is the contractual point where sellers and buyers execute the transactions for the gas (Transfer of title to gas between buyers and seller).

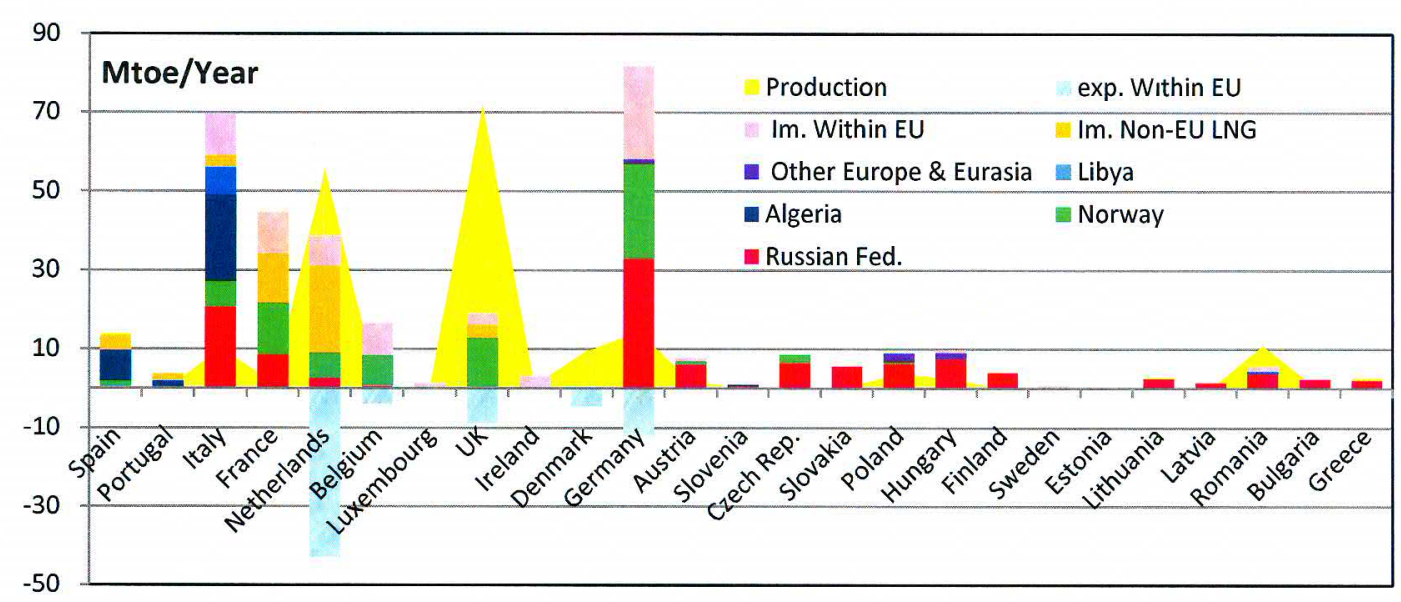

Figure 2.21 The EU gas exchange, 2006 [Source data: 7]

Trading hub can be in two forms: Physical and virtual. While in physical hub, trading is accomplished at a common delivery point, in virtual hub transaction is realized in any point of the transit line. Trading hub is a major feature of the competitive market to create market liquidity and price transparency. For the development of the liquid market in the hub where short-time multi-party deals are realized, the number of seller and buyers for volume increase from different sources is important.

Giving third party access right into transmission lines and the removal of the destination clauses in the sale and purchase agreement to restrict the re-export of gas by importer are also equally important for the development of trading hubs [5].

At present the National Balancing Point (NBP) in the UK and the Title Transfer Point (TTP) in the Netherlands are examples to the virtual trading hub. The hub Zeebrugge in Belgium and the hub in Baumgarten, Austria are the examples to physical hub. 
For instance, the hub Baumgarten in Austria, is one of the most developing transit and to a small extent trading hub where mainly Russian natural gas is transported over several pipelines to other European countries and is traded. Since the single source gas is an handicap to accelare competiton, The Austrian hub owner OMV has been working to diversify the seller in the hub, namely OMV has been working to increase the availability of a number of willing sellers of gas and the Nabucco is the result of this ambition [14].

\subsection{The EU View: Security of Supply}

The base scenario has shown the increasing import dependency up to $83 \%$ by 2030 and the existence of an un-contracted supply gap after 2015. Import dependency within the concept of the security of supply has been in the EU's agenda since 2000 at a different strength through the Green Papers released by the European Commission (EC) in 2000 [15] and 2006 [16]. Security of supply (SoS) is one of the three pillars of energy policy in the EU. The main aim of the EU energy policy is to achieve security of supply and maintain international competitiveness while protecting the environment (sustainability). This section will focus on the security of supply issue.

The EC defines the security of supply in its approved Green Paper "Towards a European strategy for the security of energy supply" in 2000 as:

"...Security of supply does not seek to maximize energy self-sufficiency or to minimize dependence, but aims to reduce the risks linked to such dependence.." and gives the strategy to limit the supply risk as "Among the objectives to be pursued are those balancing between and diversifying the various source of supply (in products and by geographical areas". From this definition it can be interpreted that security of supply is simply to maintain the physical availability of gas. Within this concept, the completion of internal market in terms of supply security is among the suggestions in the Green Paper to be paid attention.

A secure energy supply (or availability) can be managed by a combination of internal and external policies in the EU. While internal policy includes market liberalization which manages short to medium term SoS, external policy includes import dependency to secure long term SoS. Namely, external policy cannot secure 
the EU's gas needs alone. It should be complemented by fully functioning single integrated competitive internal market (liberalized market) which ensures the flow of gas throughout the EU.

The internal EU gas policy is implemented in two main ways through natural gas directive (98/30/EC) and through the application of the EU competition rules. By the introduction of Directive (98/30/EC) [17] in 1998 and then (later) accelerated directive (2003/55/EC) [17], it is aimed at creating a single and integrated market in gas, based on the abolition of natural monopolies, the removal of barriers to crossborder supplies of gas between states, and the creation of uniform competition throughout the EU. The single market will create solidarity between the states and bilateral dependencies will become irrelevant. The application of competition [18] policy through its rules such as articles $81,82,86$ regarding antitrust and merger control is complementary in achieving the liberalization in the gas market. So, the development of a single competitive internal market will foster the short term SoS through supply/demand match by the establishment of market trading hubs which mean more supplies, spot trade, and more liquidity. In 2004 following the enlargement, the EU, under the "Extended Neighborhood Policy", developed action plans that are not legal agreements with the producing and transit countries. One of the objectives was to extend the principles of the internal energy market to these countries to catch the harmony [19].

As for the external EU gas policy, it is particularly important for the long term security of supply as import dependency is expected to increase.

In this respect, the Green Paper of 2000 suggested several initiatives including continuous dialogues with external gas producing and transit countries to ensure sufficient gas flow from potential alternative supply sources through multiple export pipeline capacity in relation to long term security of supply and underlined Turkey's role as potential new energy (specifically gas) corridor country.

Actually, the EU's action plans regarding external supply security have been initiated by the European Energy Charter Process ratified in 1998, INOGATE program of 1999, and energy dialogue started with Russia in 2000 that all have been background for broader external EU energy policy.

For instance the INOGATE program is aimed at developing cross-border transport to access to markets for oil and gas production in the Caspian region, Central 
Asia, and surrounding regions including Iran [20]. These programs were supported with the Trans European Network Programme (TEN-Energy) to encourage the investor in the construction. Under the TEN-Energy program, the community cofinances feasibility studies for potential new gas supply infrastructure and joins up to $20 \%$ of investment for the priority projects of European interest, as was the case in Turkey-Greece Interconnector [21,95].

As one of the impact of Green Paper, in 2002 the Fourth Corridor via Turkey in addition to the current routes from Russia, Norway and Algeria was proposed by a consortium under the OMV leadership [14]. The feature of the Fourth Corridor is that it will have a pipeline series designed to transport gas from the Caspian region (includes Azerbaijan and Central Asian countries) and the Middle East to Europe via Turkey bypassing Russia. Within this definition, OMV led Nabucco project as the backbone of the corridor with the maximum capacity of $30 \mathrm{Bcm} / \mathrm{yr}$ will start in Turkey crossing and supplying Bulgaria, Romania, and Hungary and reach Austria to enlarge OMV's trading hub status. Nabucco was identified as a priority project in 2004 by the EC. The other pipeline Turkey- Greece-Italy Interconnector of which the first step Turkey-Greece Interconnector started its operation in 2007 to supply the Southeastern Europe is also endorsed by the EU as a part of the Fourth Corridor.

Another Green Paper [16], "A European Strategy for Sustainable, Competitive and Secure Energy" released by the European Commission on March 8, 2006 stressed the importance of the suggestions in the Green Paper of 2000 and underlined the completion of internal market, the creation of a coherent external energy policy and the priority of developing gas corridor(s) to Europe.

The discovery of the importance of the energy security on higher political level for the EU has been following the dispute between Russia and Ukraine in January 2006 that caused brief energy shortages in Europe. The paper from the Commission/SG/HR for the European Council [22] released in June 2006, referring to the dispute, clearly confirmed the realization of two key objectives: a) diversification through geographical origin and supply route, meaning developing new gas corridors to the EU from alternative sources; and b) functioning of internal markets considering the asymmetric external dependency (of CEE states, particularly) specifically towards Russia and inflexibility in supply distribution as a result of weak infrastructure between regions within the EU in the event of any supply disruption. It also stressed possible initiatives at bilateral, regional, and 
multilateral level to ensure a common and targeted external policy. Turkey's position as a potential major energy corridor was also supported at the EU level one more time in the paper.

However, the paper from the Commission/SG/HR for the Council did not question the right of Member States to maintain their own external relations to guarantee their security of supply and to choose their internal energy mix as their legitimate rights but suggested the Member States be supportive for the common policy that would help the EU develop and implement more appropriate policies and face the strategies of major external suppliers such as pricing, implicitly towards Russia. But, different policy approaches of the Member States are likely to limit the idea of common energy policy, except in the development of internal gas market and climate change objectives.

At this point, it can be said that while the EU takes the responsibility of developing and regulating the single internal market to keep the uninterrupted gas flow throughout the EU and the responsibility for diplomatic relations with external suppliers, it leaves the external security policy from commercial point of view to the Member States to secure long term supply as a risk management strategy through bilateral relations.

Considering the level of external source dependency and the Member State's point of view to this issue, especially after the participation of new Member States into the $E U$, external policy shows some difference from one state to another.

Some Member States in West Europe define supply security within the market economy concept, without giving it a political meaning, merely as a continuous flow of gas at a competitive price and pursue their strategic interest according to this and give preference to bilateral relations over the EU decision. There exists a perception that the EU especially on the Member State base does not put aside Russia due to its geographical proximity and vast energy sources. Germany, France, Italy, and the Netherlands of west Europe are not willing to isolate and want a long-term energy relationship with Russia [23]. For instance, the Nord Stream cross-border gas transit project of Germany; and the gas distribution to end users of Italy and France with Russia within the controlled reciprocity concept are present examples of this act. It is believed that as the integrated gas market and hub concept develop spontaneous re-allocation of physical flow across markets increase [24]. It should be known that, as indicated in the previous section, the above mentioned states have a diversified 
supplier portfolio. The share of 4 major suppliers, Russia, Norway, Algeria, and LNG in their supply portfolio does not exceed $30 \%$, except Germany. So these states do not concern the source origin. According to them, diversification of route even if it involves one supplier, will reduce the risk of supply disruption as is the case for Nord Stream project that was endorsed by the EU as a priority project. The economic consideration appears to remain as an important parameter rather than the geopolitical interest. However, while these states are relaxed in relations with Russia, they on the other hand, worry about ability of Russia to meet the EU's growing need. There is a widely believed speculation that Russia may not meet export commitments due to difficulties in maintaining its production, its intention to explore eastern markets and necessity of repairs in the ageing gas export infrastructures.

As for the new Member States, they do not have the possibility to diversify their supply presently. On the average, they import $65 \%$ of their gas consumption only from one supplier, Russia, and they are convinced that they would face a severe energy security challenge due to the past and current experiences with Russia. Therefore, some of the Member States promote a "strategic approach" to supply security and prefer to distance from Russia. The leading states in this group are Poland [25] and the Baltic States that would like to reduce their over dependence on Russia through diversification and through a collective stance. The plan for diversification is to build LNG facilities in Poland and accelerating the Fourth Corridor main pipeline Nabucco [25]. As for the collective stance, Poland needs supporters. But it may not be possible as some new states like Bulgaria and Hungary think like western states as in the case of South Stream project conducted by Russia.

The EU supports Nabucco for the supply security of the CEE region. But in this case, the EU was caught between the US and Russia/Iran. The US policy is aimed at creating alternatives to Russian monopolistic policy in the Caspian region. While the US proposes the east-west route which is named as the Fourth Corridor in our study bypassing Russia, it does not want any Russian gas in the corridor pipelines. It was reiterated by OMV, the creator of Nabucco, that primary justification for the line was not demand, but the need to diversify Europe's gas supply away from Russia [26].

The US government is also very clear in its position toward Iran. Although Europe needs Iranian gas to implement the Nabucco project, the US is decisively against 
any contracts with Iran and does not support any pipeline through Iran and carrying Iranian gas to the western markets.

Today the EU has balanced itself between market and geopolitics. However, at the end, the market rule which is one of main action items for the internal gas market developments will be more important as stated in the EU regulations than the geopolitics.

As a result, it may be concluded that gas import dependency is not seen as a critical issue, as the necessary importance is given to the completion of internal gas market, energy efficiency, and the diversification in fuel mix. Especially full functioning internal gas market that will provide a free and un-interrupted flow of gas throughout Europe will make dependency to single country irrelevant. This will make the Fourth Corridor a supplementary source for the internal gas market to increase a competition rather than a priority to mitigate a demand gap. However, the EU is committed to provide a political support for the Fourth Corridor. 


\section{CHAPTER 3}

\section{PRODUCING COUNTRIES: EXPORT POTENTIALS}

The Russian Federation ("Russia"), Azerbaijan, Central Asian Countries of Kazakhstan, Uzbekistan, and Turkmenistan, and two Gulf countries Iran and Iraq hold the world's largest natural gas reserves in aggregate.

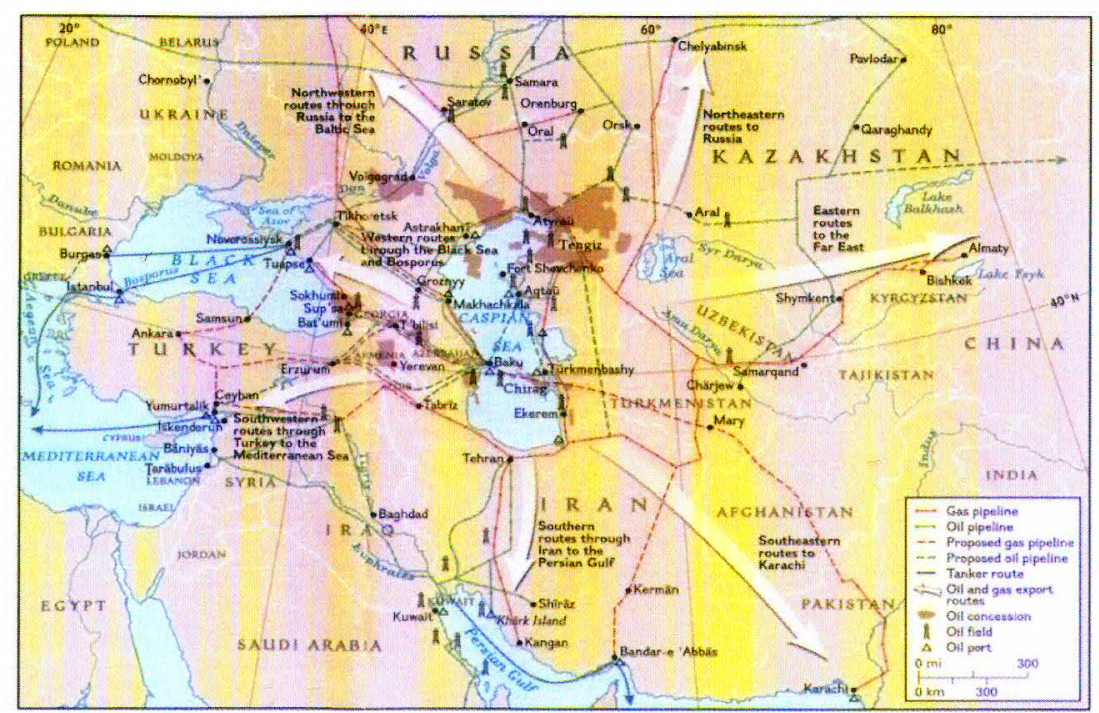

Figure 3.1 Geographical outlook - Gas exporting states [27]

The geographical location (Figure 3.1) and the vast natural gas reserves in the producing countries in theory should provide an opportunity for large scale natural gas supplies in a variety of directions.

Among these states, Azerbaijan has made clear its shipment direction to westward to Georgia to Turkey and from there to Southeastern Europe.

Central Asian Countries, who opened their doors to the world through a declared multi-vector energy policy after they gained their independence, set their strategic objective as the creation of multi-route system for their energy exports. This could be: westbound direction to Turkey via Azerbaijan or Iran and onwards to market in 
Central and Southern Europe; eastbound route to China; and old fashion northbound direction to Russia.

The Gulf Countries of Iran and Iraq, although they contain recognized reserve figures, have been struggling with internal and external technical and political constraints.

As explained in the previous section, the EU is on the way to diversify its supply in terms of source and route. One of the diversification efforts is to utilize the wide gas potential in the Central Asia and Gulf states and to carry it to Europe via Turkey.

In this chapter the above indicated producers will be examined in terms of their export opportunities.

The source data used for the analysis is taken from CERA [28]. The source data does take into account: the fields producing, and waiting to be produced having proven and/or probable reserves; and investment difficulties.

Before going further, single pipeline infrastructure (Figure 3.2) inherited from Soviet Union includes Russia and Central Asian Countries will be explained to refrain from repetitions.

\subsection{Overview of Infrastructure: Present Status}

The currently running single gas transmission infrastructure is the Soviet era system which was designed to handle all the gas flow originating from two sources: a) Prolific West Siberian gas in Russia to Europe; and b) Central Asian gas located mainly in Turkmenistan, and Uzbekistan, and to a small extent in Kazakhstan to Russia.

A-The route from West Siberia consists of three main export pipeline systems (Figure 3.3). The most important one is the Brotherhood line. It crosses over Ukraine and Slovakia, and then splits into two branches. One reaches Hungary and Austria, the other the Czech Republic and Germany. Its capacity is about $125 \mathrm{Bcm} / \mathrm{yr}$. Italy and France takes gas from that trunk line. The second one is the Yamal-West Europe Pipeline. It crosses Belarus and Poland to end in Germany. Its capacity is 38 
$\mathrm{Bcm} / \mathrm{yr}$. The Netherlands takes gas from that line. The third one is the Soyuz trunk line. It crosses Ukraine, Romania and Bulgaria to end in Turkey. Its capacity is 28 $\mathrm{Bcm} / \mathrm{yr}[1]$.

B-The route from Central Asia directly to Russia consists of two main trunk lines (Figure 3.4): Central-Asia-Center (CAC) pipeline series [29] originating from Turkmenistan; and Bukhara-Ural pipeline originating from Uzbekistan.

CAC series, starting from Turkmenistan, has 5 pipelines CAC-1, 5 . While CAC-1, 2 , 4 , and 5 cross Uzbekistan and Kazakhstan and are connected to major Russian export pipelines in Russia, CAC-3 runs along the coast of the Caspian sea and is connected to the CAC series again in Kazakhstan. There are several branches of CAC series. The important one is the between Makat, Kazakhstan and Russian Caucasus.

Bukhara-Ural pipeline is originated in Uzbekistan and after crossing Kazakhstan is connected to the Russian system.

The theoretical capacity of these two main trunk lines running into Russia including branch to Caucasia is $100.5-122.8 \mathrm{Bcm} / \mathrm{yr}$. Of this, $50-68 \mathrm{Bcm}$ is carried by CAC-1, $2,4,5,10 \mathrm{Bcm}$ is carried by CAC-3, $15-19.3 \mathrm{Bcm}$ is carried by Bukhara-Ural, and $25.5 \mathrm{Bcm}$ is carried to North Caucasus via Makat, Kazakhstan.

However, presently practicing total capacity of these trunk lines is $63-77 \mathrm{Bcm} / \mathrm{yr}$. Of this, CAC-1, 2, 4, 5 holds $45 \mathrm{Bcm}$ via Turkmenistan to $50 \mathrm{Bcm}$ via Uzbekistan. CAC3 holds 3-5 Bcm and Bukhara-Ural holds about 5-7 Bcm. The share of Makat-North Caucasus is assumed $10-15 \mathrm{Bcm}$ [29].

Other than these main network, there are several small to medium size pipelines running from Kazakhstan to Orenburg- Russia, from Russia to Azerbaijan, small local lines from Uzbekistan to neighboring countries for regional exports, and from Turkmenistan to Iran that is the only line constructed after the break-up of Soviet Union.

As observed, the pipeline system ensures that even today Central Asian gas producing countries are still physically reliant on the Russian gas pipeline system. 


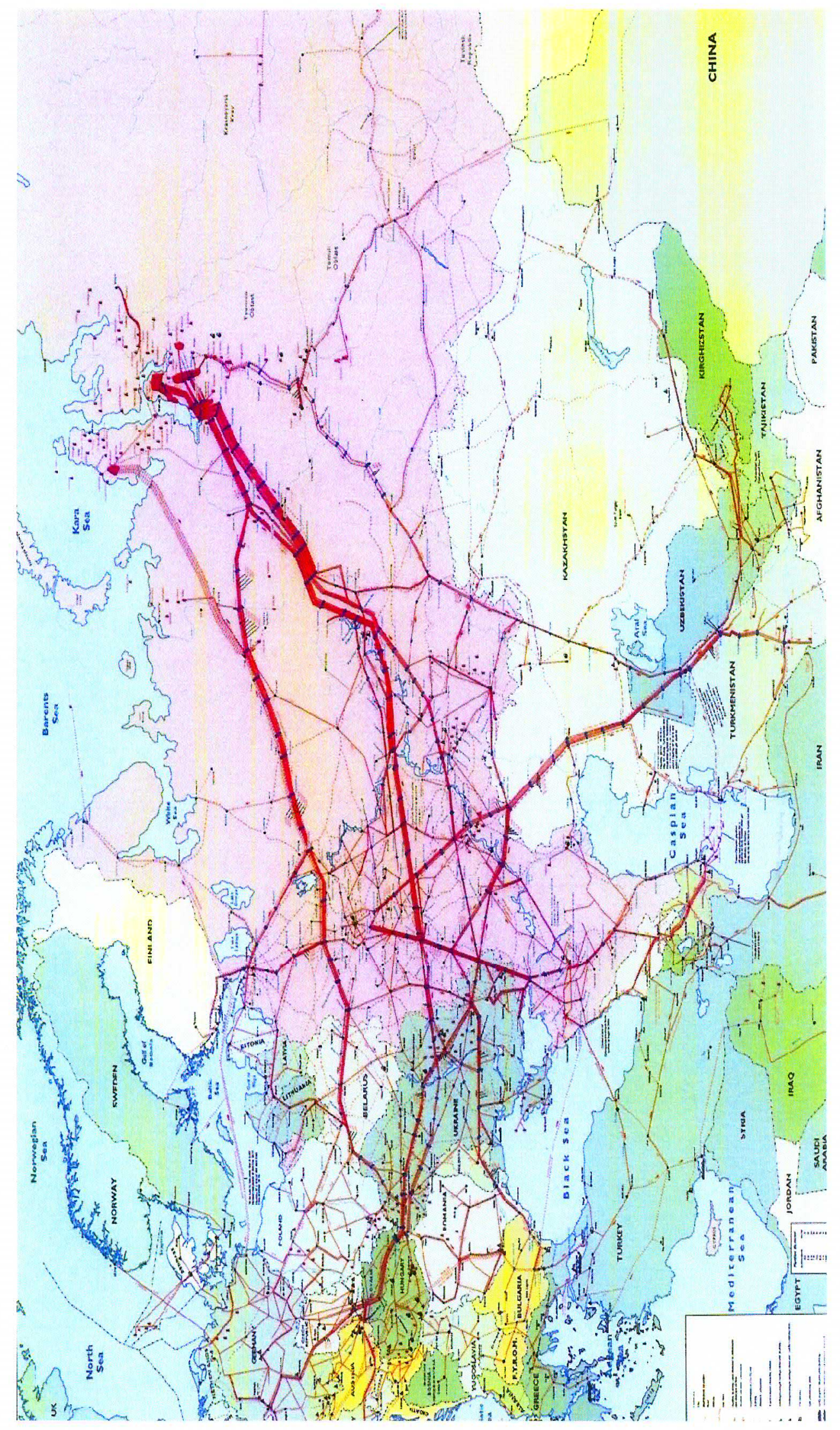

Figure 3.2 Eurasian single gas transmission network [30] 


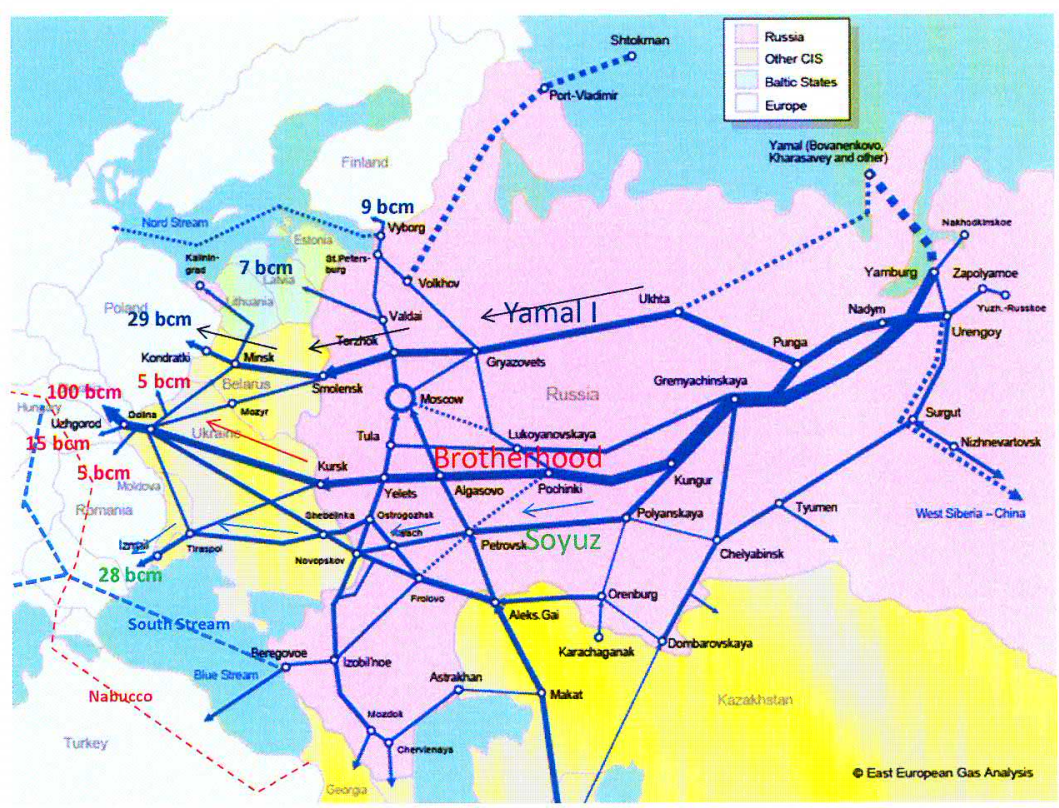

Figure 3.3 Russian pipeline network and final export point [31]

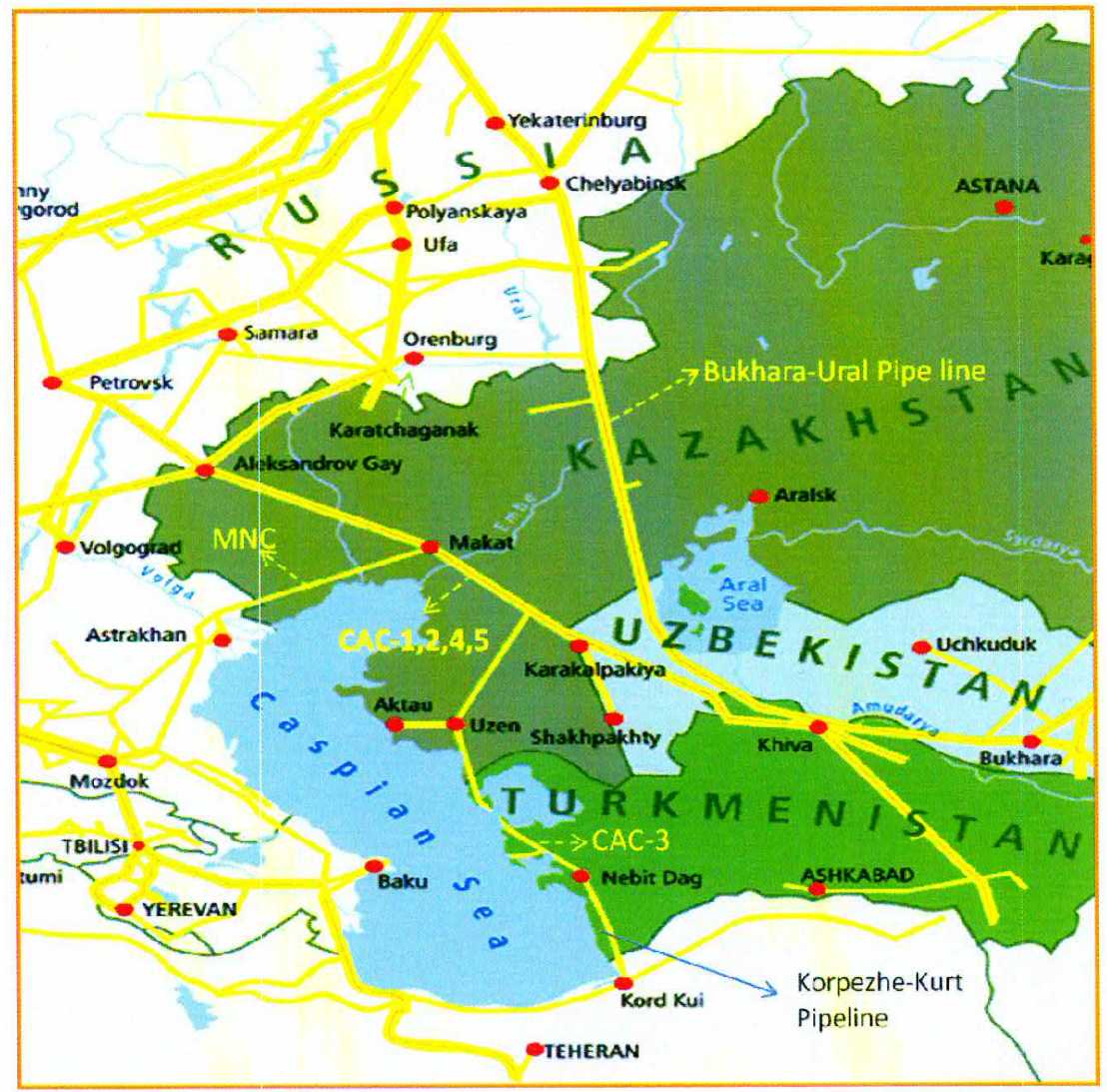

Figure 3.4 Central Asia pipeline network [31] 


\subsection{Russia}

\subsubsection{Reserves}

Russia is the largest gas reserves holder. Its proven and probable natural gas reserves as of 2007 are estimated at more than $45 \mathrm{Tcm}$ in total, $26 \%$ of the world gas reserves. Of this total, $60 \%$ belongs to Gazprom with $29.85 \mathrm{Tcm}$. $21 \%$ is held by oil companies and independents and $19 \%$ is unallocated [32]. Major reserves are located in West Siberia and Volga-Ural regions where infrastructure is mature enough. It is certain that gas reserves are sufficient to supply Europe for many decades, but what is not certain are whether the reserves will be opened into production timely to meet the increasing domestic demands and export commitment.

\subsubsection{Production}

In 2007, Russia produced total $653 \mathrm{Bcm}$ of gas [32], a drop of $1 \%$ compared to 2006. According to Gazprom, this reduction was due to lower gas consumption in Europe [32] driven by warm weather.

Historically, Russian gas production had reached that production in 1991. The collapse of the Soviet Union led to a slight decrease of production. After the lowest point was reached in 1997 with $562 \mathrm{Bcm} / \mathrm{yr}$, production with the development of new major fields showed upward trend starting in 2001 (Figure 3.5).

Today, the gas output of 2007, has already exceeded the forecast value of 650 $\mathrm{Bcm} / \mathrm{yr}$ for 2010 released in the Russian Energy Strategy to 2020, approved by the government in 2003 [33].

Natural gas production is carried out by Gazprom and its affiliates, independents and oil Companies.

Of total production in 2007, Gazprom as the country's largest gas producer is responsible for $84 \%$ with $548 \mathrm{Bcm}$ [34], rest (16\%) is provided by independents and oil companies, as a free and associated gas. 
The bulk of Gazprom's gas production comes from three super-giant fields in Nadym-Pur-Taz region (Figure 3.5) of West Siberia which now are in decline. Gazprom is expecting to overcome this decline through a field put into production in the end of 2007 with a $25 \mathrm{Bcm} / \mathrm{yr}$ plateau rate [35] and Yamal where production is expected to start in 2011. The Yamal development is a key significance for securing domestic need and export commitment as well.

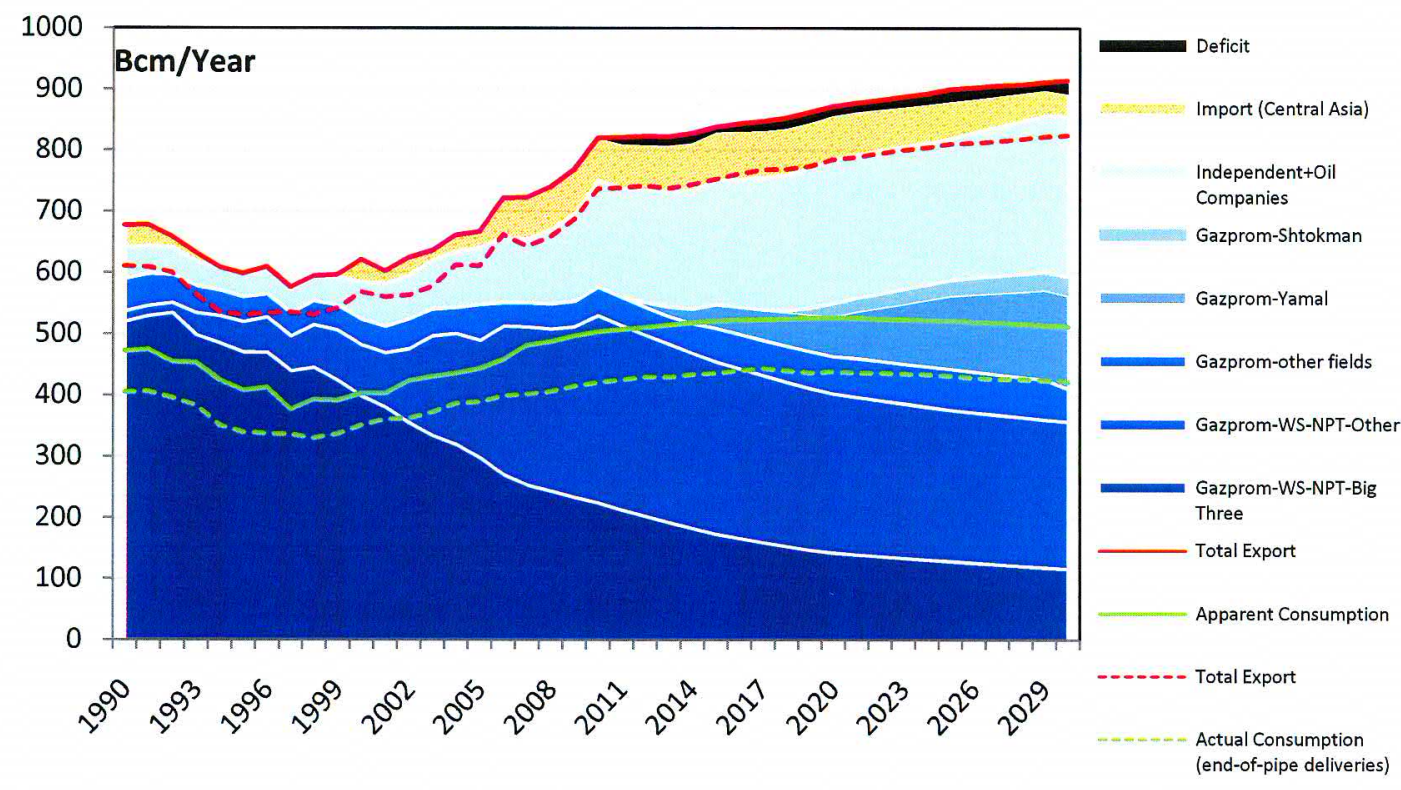

Figure 3.5 Russia gas balance [Source data: 28]

According to Gazprom, by the end of next decade roughly half of the Gazprom output will originate from the new fields [34].

Russian domestic gas production (Figure 3.5) will be $750 \mathrm{Bcm} / \mathrm{yr}$ in 2010 and 783 $\mathrm{Bcm} / \mathrm{yr}$ in 2020. The figure also reveals that, taking into account domestic consumption and export requirements, the small deficit of $15 \mathrm{Bcm}$ Russia experienced in 2005 will reach around $70 \mathrm{Bcm}$ in 2010 and $88 \mathrm{Bcm}$ in 2020.

\subsubsection{Import}

Russia to meet above indicated deficit depends on Central Asian gas (Figure 3.6). The Imports from Central Asia provide an important supply bridge. The deficit after 
the import will be around $10-15 \mathrm{Bcm} / \mathrm{yr}$ after 2012 and will not pose any risk of not being able to meet export obligations.

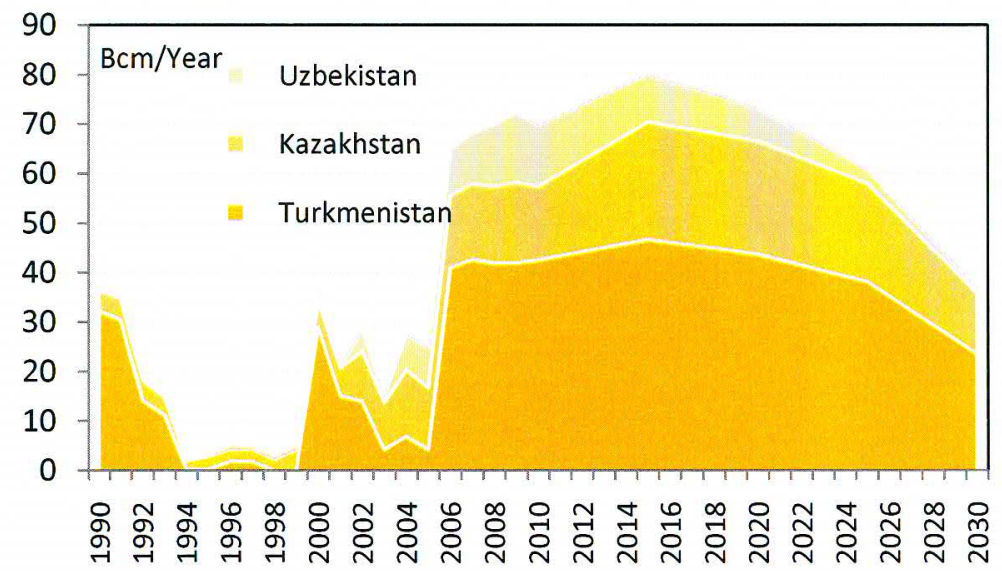

Figure 3.6 Russian gas import profile [Source data: 28]

\subsubsection{Export}

In 2007, Russian gas exports amounted to $237 \mathrm{Bcm}$. All export is realized by Gazprom, which is the only Russian gas export monopoly by the law. Of this volume, $129 \mathrm{Bcm}$ was exported to the $\mathrm{EU}, 85 \mathrm{Bcm}$ to the $\mathrm{CIS}$ and $\mathrm{FSU}$, and $23 \mathrm{Bcm}$ to Turkey (Figure 3.7).

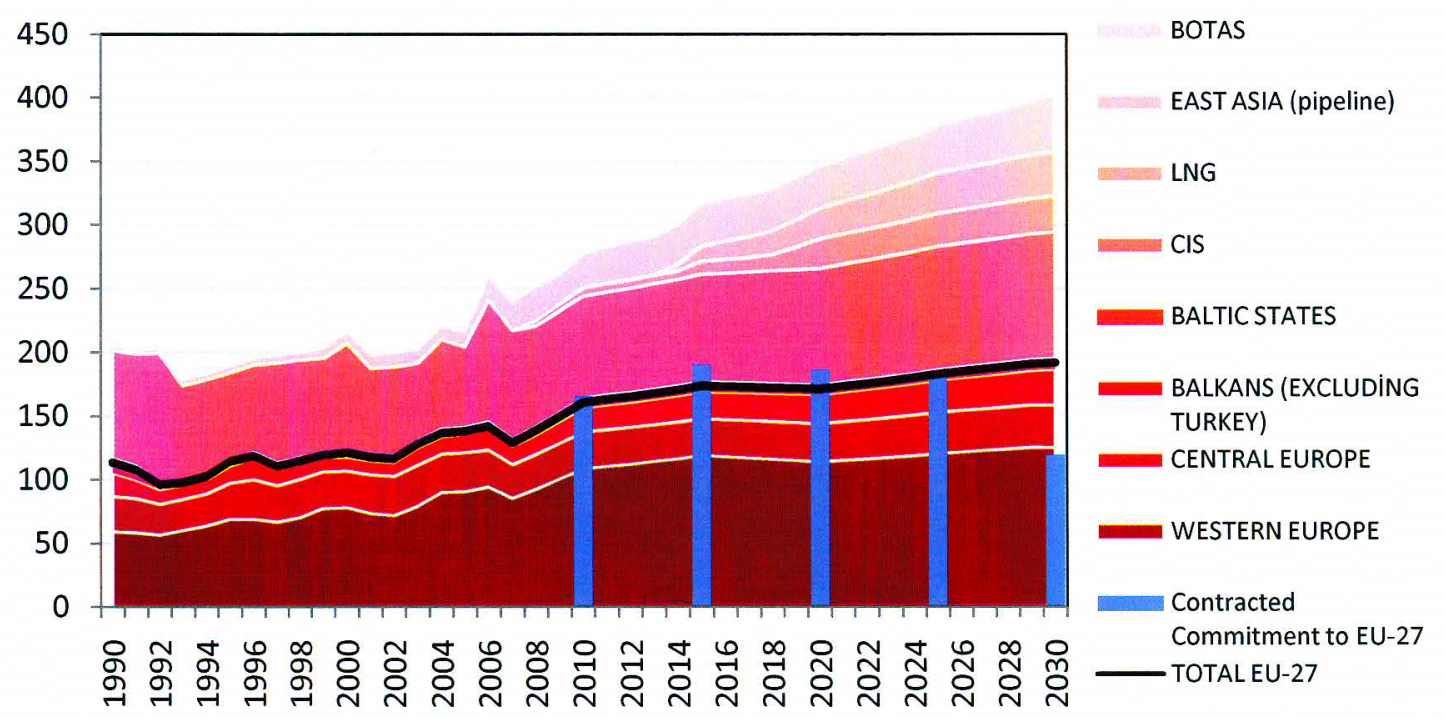

Figure 3.7 Russia gas export profile versus commitment [Source data: 11, 28] 
As observed from Figure 3.7, Russia will diversify its gas export to new markets via pipeline to East Asia and via LNG to global market. But this will not cause any disruption in the EU and Russia will obey its commitments as assured by Prime Minister V. Putin [36]. For the short to mid-term duration there will not be any gas export shortage to the EU-27 on the contrary to the EU's doubts. There will be a slight deficiency in meeting the contractual volumes for the EU in the next decade until 2020. However, since real consumption is usually less than contractual nominal value, it is expected that this deficiency will not affect the commitments.

Russia does not see any problem regarding gas export commitments with the support of contracted gas flow from Central Asia to Russia. Today, Russia has been extending its long-term contracts with major European buyers especially from France, Italy, and Germany. What Russia sees as a problem is with the reliable transport capacity. Namely, problems with its transit country neighbors are the cause of concern. Russia, to reduce the effects of transit countries ( $80 \%$ of its export volume to the EU crosses Ukraine) and let the direct access to consumers, is working on a two new pipeline projects. These Projects are Nord Stream and South Stream.

Nord Stream pipeline project [34] decided in 2005 will give Russia direct access to the West European market through a 1,200 km offshore pipe that will link the Vyborg area in Leningrad Oblast with Germany across the Baltic Sea. Plans are to construct two strings with a yearly total capacity of $55 \mathrm{Bcm} / \mathrm{yr}$. This project is considered by the EU as a priority project and it has been included in the Trans-European Network [37]. This pipeline is expected to carry brand new gas from Shtokman gas field

South Stream project [34] entails building a pipeline under the Black Sea from Russia to Bulgaria. It will start near Beregovaya, also the starting point of the Blue Stream pipeline, in Russia and run over some $900 \mathrm{~km}$ across the Black Sea to the Bulgarian coast, reaching a maximum water depth of over 2,000 m. From Bulgaria, two branches are being envisaged, one branch will go to Southern Italy crossing Greece, and the other branch will run through Serbia, Hungary, Austria or Slovenia to Northern Italy. Project is due to be completed in 2013 to carry $30 \mathrm{Bcm} / \mathrm{yr}$ gas. More than $50 \%$ of the gas in the project will meet the existing obligation and rest will try to capture new market space in Central to Southern Europe [38]. 
Russia as a reliable supplier has been exporting gas to the EU since 1968 under long-term containing take or pay provision agreements that derive from Intergovernmental framework treaties.

Actually gas exports of Russia to the West commenced with supply of small volumes of gas to Poland in the mid-1950s during the former Soviet Union. With the development of pipeline system by the end of the 1960s gas export was enlarged to include the former Czechoslovakia in 1967 and Austria in 1968. All states in Eastern Europe (Poland, Hungary, Czechoslovakia, Bulgaria, Eastern Germany, and Romania) and the former Yugoslavia began to receive Russian gas during 1970s. West Germany, France, Italy, Finland started buying gas from Russia at the same time and Greece was added to the list of importers in the 1980s [39].

After the break-up of The Soviet Union in 1991, the volume of supply to Eastern Europe began gradually shrinking by the fall in gas demand while shipment to Western Europe rose (Figure 3.8).

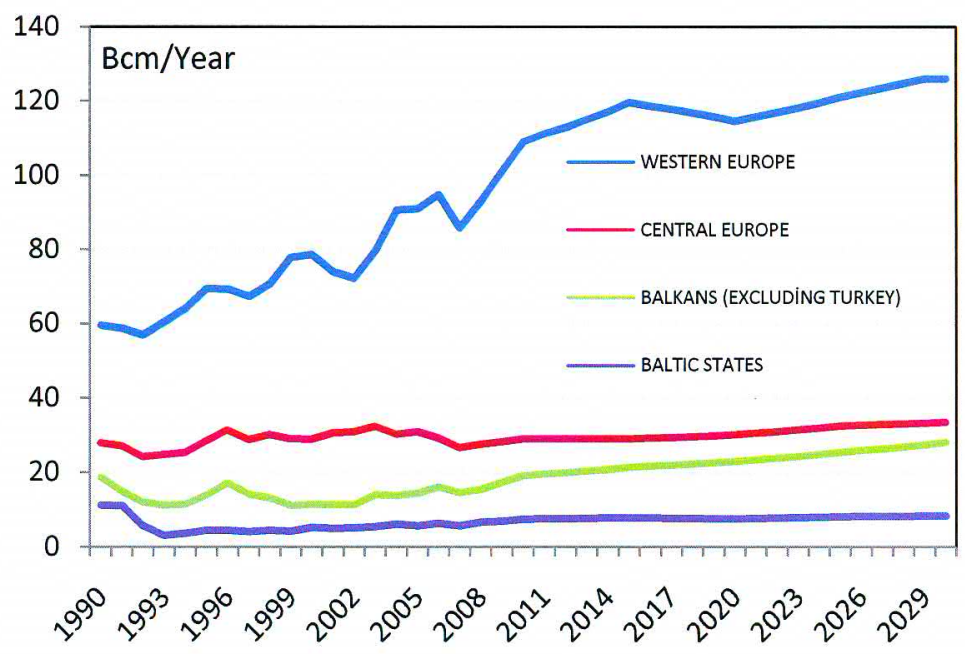

Figure 3.8 Regional look for the share of Russian gas in Europe [Source data: 28]

Although, the history proves the Russian reliability on uninterrupted gas export, the ability of Russia to produce (or to have) enough gas for its domestic demand and Europe's growing needs is the long term worry for the EU. 


\subsubsection{Energy Strategy}

Russian energy strategy against the above worry can be clarified in the below internal and external objectives.

The first objective is free/associate gas production of independent /oil company and internal market efficiency.

Independents and oil companies are becoming important players in free and associate gas production to prevent decline and help increase in production. However, their ambitions to produce gas are discouraged by difficulties of access to the Russian gas transmission system called as "the Unified Gas Supply System (UGSS)" which is owned by Gazprom. This difficulty creates even more problems for the associate gas. Independents may control the free gas production and produce in the volume they may market, but oil companies cannot control the production of the associate gas as a byproduct of crude. They may either flare the gas they cannot utilize or cut the oil production. All are somewhat an economic loss.

Official Russian figure for flared gas was $15 \mathrm{Bcm}$ in 2005 [40]. This figure, according to the World Bank estimates, is about $38 \mathrm{Bcm} / \mathrm{yr}$ today [41] (one-third of annual associate gas production in Russia or expected consumption value of Turkey in the year of 2008). According to Independents and oil companies, this difficulty can only be solved in case they are given long term guaranteed access to Gazprom's gas transmission network [42]. Otherwise, investment to produce and utilize more free / associate gas may not be possible [43].

Recently, Government has taken initiative to solve the problem on Gazprom's reluctance to give access, so called as the capacity limitation. The President Medvedev and Prime Minister Putin separately announced that Gazprom would have to start letting other producers have third party access right. Moreover, Deputy Prime Minister Sechin ordered Gazprom and the Federal anti-monopoly service to prepare a plan. This is a positive development in terms of utilizing associate gas efficiently for the market. In the case of access to pipeline with no-quota, Independents share of output would rise to $30 \%$ [44].

As for the efficiency, Russian economy is heavily dependent on natural gas with inefficient use due to subsidized gas price. Government through new technology 
would like to reduce the inefficient use of gas by upgrading the existing infrastructure and developing a new one. According to estimates, $10-15 \mathrm{Bcm} / \mathrm{yr}$ gas will be saved [35]. In addition, as seen in Figure 3.5, there will be around $70 \mathrm{Bcm} / \mathrm{yr}$ gas consumption /loss in the pipelines (difference between apparent consumption and actual consumption). Gazprom has been working to reduce this to a reasonable level.

These alternative supplies, especially increase in the independent production will be able to reduce the worry.

The second objective is towards the EU. Gazprom's EU strategy is about market power. Gazprom would like to be within whole chain of supply. So, it is essential for Russia through Gazprom: a) to maintain market leading position and provide for reliable gas. This is planned to be achieved through developing relationships with traditional costumers on a long term contractual basis and through using trading hubs on short term; b) to raise the efficiency of natural gas sales through participation in downstream gas distribution [45, 46] (Figure 3.9). Russia with the decision of trading to end market will be able to try to compensate the supply profit risk. Gazprom, since the late 1990s, has established joint ventures such as in Baltic States, Germany, Italy, and France. Recent purchase of $50 \%$ in OMV's subsidiary "Central Europe Gas Hub" in Baumgarten in Austria is the latest transaction to reach the target of short term trading.

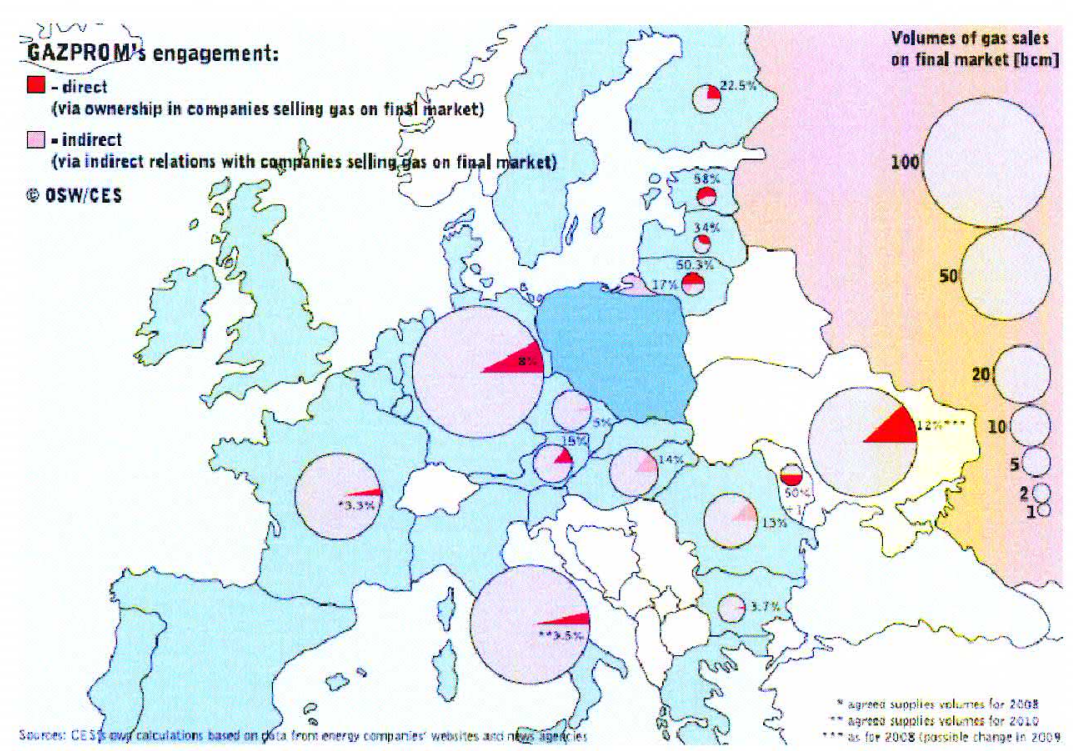

Figure 3.9 Gazprom's downstream activities in the EU [8] 
The third objective is towards Central Asia. This is the most important objective for Russia since Central Asian gas consistently plays a significant role in Russian energy strategy [33]. This objective can be analyzed in four strategies: gas supply and transit of it, Infrastructure (upgrading of CAC system and construction of new lines), upstream activities, and purchase pricing mechanism.

Among these, the most important strategy for Russia is to defend its preferential position as a transit bridge towards the EU and a privileged buyer of Central Asian gas. On technical level, Gazprom plays a leading role for Russian objectives in the region, negotiating deals for long-term supply of gas through its pipeline system. On the political level historical and personal ties with the leaders of the region, Russian strategy performs efficiently [47].

In the late 1990's, "gas bridge" policy [34, 48] was developed by Gazprom as a basic supply strategy. The utilization of Central Asian gas was one of the priorities in that policy. This strategy was reiterated in Russia's Energy Strategy to 2020 announced in 2003[33]. According to the Strategy text, Central Asian gas is expected to supplement Russia's gas exports through re-establishing its extraction-supply and networking chain on the territory of the Central Asia and expand its traditional consumer markets in West and Central to Eastern Europe. Russia, taking advantage of Soviet legacy, has been showing all the effort to utilize Central Asian gas into the Gazprom's resource portfolio in order to minimize Gazprom's investment burden in Russia.

In May 2007, energy summit attended by Kazakhstan, Russia, and Turkmenistan fortified Russia's position as the main transit corridor for the Central Asian hydrocarbons moved to Europe. The presidents agreed on the long-term prospects. The reconstruction of CAC pipeline infrastructure and developing new gas transmission lines- PreCaspian pipeline parallel from Turkmenistan to Russia via Kazakhstan and Uzbek-Russia pipeline parallel to CAC system- will expand opportunities for Gazprom to include larger gas volumes of region to its supply balance. Today, Russia has a strong contractual and legal framework for the strategic cooperation with all of the producers in the Central Asia [34].

Russia, in order to guarantee the supply volume, entered into Turkmenistan and Uzbekistan for field development with its upstream companies, and offered central 
Asian producers a purchasing price on European market basis. The just statements made by the EU and the US officials offering Central Asian Producers much higher purchase price than what Russia has been giving created the competition to purchase the gas. Prices went high when Russia moved to increase the purchase prices to the European level starting in 2009. Russia with this proactive action neutralized the EU's bargaining advantage.

\subsection{Azerbaijan}

\subsubsection{Reserves}

The country's known reserve is around $1.5 \mathrm{Tcm}$. A very disappointing exploration phase (The negative results of these offshore wildcats) in the Azeri sector of the Caspian Sea between late 1990 and 2005 has substantially downgraded the expectation of higher gas reserves of Azerbaijan. Main gas assets are producing Shah Deniz and potential unproduced ACG non-associated gas reserves. Other than these, there are several medium to small size producing or waiting to be produced marginal fields.

\subsubsection{Production}

In 2007, Azerbaijan produced $11.5 \mathrm{Bcm}$ of gas (figure 3.10). Producers were SOCAR (with JV's and PSA's) with $5.9 \mathrm{Bcm}$, Azerbaijan International Operating Company (AIOC) with $2.4 \mathrm{Bcm}$, and new Shah Deniz consortium with $3.16 \mathrm{Bcm}$. It is expected that the Azerbaijan gas production will increase to $17 \mathrm{Bcm}$ in 2010 , to $35 \mathrm{Bcm}$ in 2015 and to $40 \mathrm{Bcm}$ in 2020 . The projection also includes half production Kepez. The increase in gas production over the projection will depend on successful exploration in the Caspian Sea such as Alov which is a disputed block between Iran and Azerbaijan due to partition of the Caspian Sea and it is not expected to be solved in the medium term. 


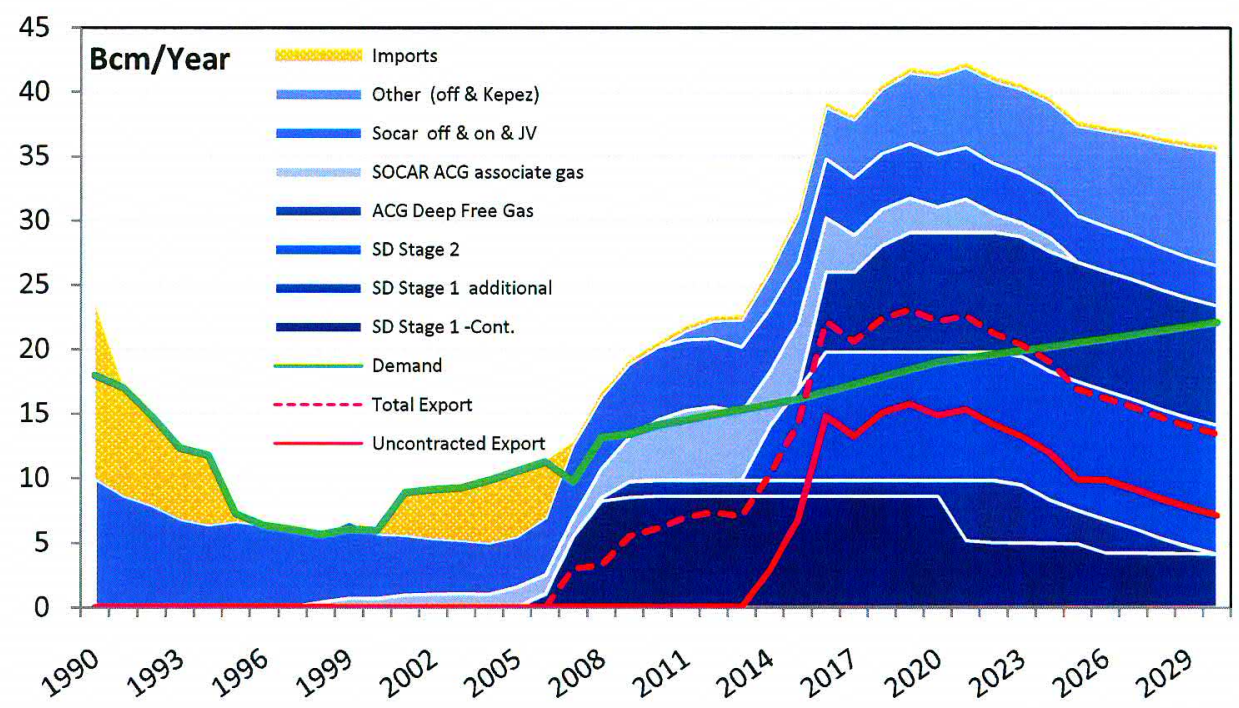

Figure 3.10 Azerbaijan gas balance [Source data: 28]

\subsubsection{Export}

Azerbaijan became an exporter country after the Shah Deniz project stage I gas commenced its production life in November 2006. However, due to technical problems related to the production wells in the field, the continuous production and the export started after March 2007. In 2007, Azerbaijan exported $1.3 \mathrm{Bcm} / \mathrm{yr}$ gas to Turkey who is the main buyer of this gas with $6.6 \mathrm{Bcm} / \mathrm{yr}$ out of production of 8.5 Bcm/yr. Export of Shah Deniz stage I gas (present export of Azerbaijan gas) is controlled and operated by Azerbaijan Gas Supply Company established by Shah Deniz project partners.

Azerbaijan exports its gas through the South Caucasus Pipeline (SCP) (One step toward an alternative gas corridor to Europe), connecting Baku to Erzurum in Turkey, via Georgia, which will deliver $6.6 \mathrm{Bcm} / \mathrm{yr}$ of gas to Turkey per year under an existing gas purchase agreement. The initial (current) capacity of the gas pipeline is $8.4 \mathrm{Bcm}$ per year. Its throughput capacity will be increased to up to $22 \mathrm{Bcm}$ per annum, with the potential of second phase of Shah Deniz to be ready in 2014 and ACG deep gas to be ready around 2017, both aiming at European gas markets. Azerbaijan's proximity to Turkey makes its position very competitive on Turkish and southeastern European markets. 
Azerbaijan, also, has one small regional Hajigabul-Astara-Bindbiand gas pipeline which was used to supply Iranian gas to the Trans-Caucasus republics in the Soviet times. This line is used to supply gas to Iran at a small amount when it is requested by Iran as was done in February 2008 and to the Nakhchivan Autonomous Republic since November 2006 through swap by Iran [49].

The export capacity (Figure 3.10) of Azerbaijan is expected to reach maximum level of $20 \mathrm{Bcm} / \mathrm{yr}$ in 2020. But, after subtracting contracted 7.4 Bcm/yr Shah Deniz stage I gas, the maximum non-contracted gas volume to be exported for the demanding market will be approximately $13 \mathrm{Bcm} / \mathrm{yr}$ starting in 2016 if ACG deep gas is put into production in scheduled time scale.

In November 2006 the EU and Azerbaijan signed a Memorandum of Understanding (MoU), as a result of the Green Paper published in 2006. One priority in the MoU is to enhance the safety and security of energy supplies and transit system from Azerbaijan to the EU including bringing Azeri gas to the EU market through Turkey. The more anxious country for Azeri gas is the US. The US woos Azerbaijan as a key partner and a potential supplier of the EU via Turkey. It believes and imposes that there is sufficient gas just in Azerbaijan to do Nabucco as well as the TurkeyGreece-Italy pipeline, and assumes that the sufficiency is as much to replace onequarter of gas that Russia exports to Europe [50], implying around $40 \mathrm{Bcm} / \mathrm{yr}$ gas which is equal to the maximum gross production of the Azerbaijan who will reach that in 2020s.

Unfortunately reality is that non-contracted Azerbaijan gas will be just enough to fill the Turkey-Greece- Italy Interconnector which will have capacity of $12 \mathrm{Bcm} / \mathrm{yr}$ if this gas is not directed to Turkish local market or to somewhere else.

In the summer of 2006, Shah Deniz project partners, within the concept of marketing stage II gas, conducted a work on regional market opportunities including transportation routes. Conclusion was that Turkey was seen as one of most possible market from commercial point of view subject to both regulatory and competition law issues and as viable transit country to transport the gas to the EU in case Turkey would like too.

Although Azerbaijan stuck to MoU and lately Azerbaijan President reiterated that his country would continue its efforts to guarantee the EU's energy security, however, there occurred some issues that make the marketing of gas to the EU a little 
complicated. The first issue is related to the application of the EU competition rules, Article 81. The European Commission, in order to facilitate broader available gas volumes and so to increase market liquidity within the EU under the short term security concept, requires producers to refrain from jointly marketing gas from individual fields. These rules are valid not only for Shah Deniz but also for all multicompany projects who would like to direct their gas to the EU. Shah Deniz project stage II was assumed in this category since it is composed of more than one company to produce and market the gas. And, since only marketing of the aggregated gas volume (combined sales of the gas shares of Azerbaijan State and Shah Deniz partners in the project) makes the project valuable, the partners looked for other markets including Russia and Iran where the EU competition rules were not valid. But recently the European Commission exempted Shah Deniz stage II from normal EU competition rule(s) [51]. The second issue is related to the different points of partner views for the marketing. Not all the partners have agreed on the same point as a result of their possible geopolitical, commercial, and other preferences. The third issue is transit regime, more specifically transparent transit fee to be paid to transit countries Georgia and Turkey. Azerbaijan, for transiting its gas, expects to pay a normal transparent commercial fee that includes capital/operating cost of pipeline and transit tariff. The EU mentioned in that context that it would appeal to Georgia and particularly to Turkey to guarantee fair and transparent transit conditions and urge Azerbaijan to support the Fourth Corridor as a significant exporter. Despite the positive comments from the EU regarding transit fees, Azerbaijan has not been convinced and now is in the negotiation table with Russia to sell part of the field's output to Gazprom. There is a gas pipeline from Baku to Astrakhan along the coast which is currently used to pump gas into Azerbaijan for domestic needs. If reversed and upgraded, the link could easily reach an intake of several billion cubic meters a year for Gazprom to purchase [49].

If Azerbaijan decides to pump all potential un-contracted $13 \mathrm{Bcm} / \mathrm{yr}$ export gas to the EU via Turkey, it will be able to realize his wish through existing infrastructure in Turkey with Turkey-Greece Interconnector to Greece and then to Italy after the completion of Italy section. Azerbaijan will seek to retain title to gas during crossing Turkey. The closest sales point will be the Turkey/the EU border.

Considering the maximum export volume, the TGI option is likely to postpone the Nabucco project. 


\subsection{Kazakhstan}

\subsubsection{Reserves}

Proven and probable free and associated gas reserves as of end 2007 are estimated as $3.2 \mathrm{Tcm}$ [52].

\subsubsection{Production}

In 2007, Kazakhstan had produced a total of gross $29.64 \mathrm{Bcm}$ of gas, of which $43 \%$ comes as associated gas from oil fields. Almost half of the 2007 production was produced by Karachaganak Integrated Organization. Other major contributors included TengizChevroil, and State company KazMunaiGas [52] (Figure 3.11).

Since Kazakhstan largely counts on associated gas production, level of volume depends on especially how and when oil fields are to reach their full capacity production. As shown in the Figure 3.6, Kazakhstan's sales gas (by definition usable gas for domestic demand after subtracting re-injected gas into the oil fields to enhance oil production and flared gas from gross production volume) production will be $20 \mathrm{Bcm}$ in 2010 and reach $30 \mathrm{Bcm}$ in 2020.

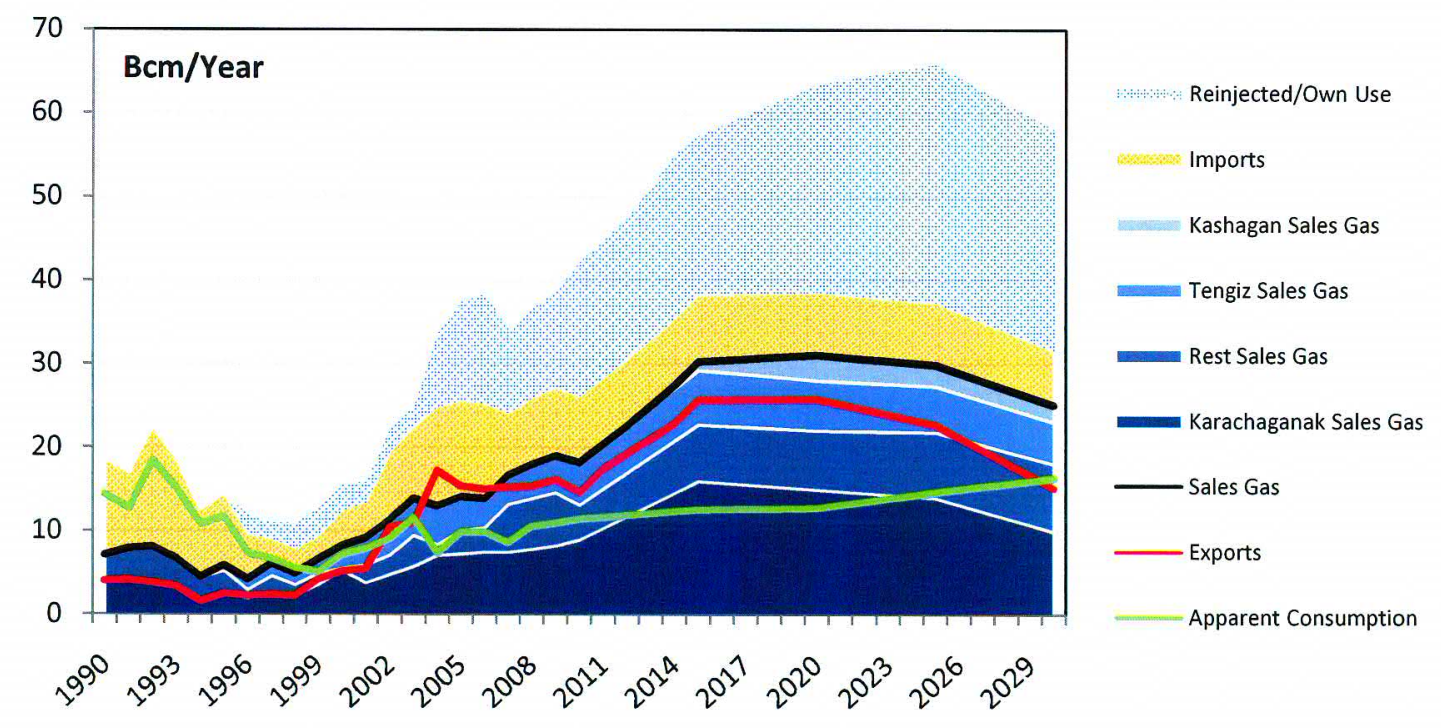

Figure 3.11 Kazakhstan gas balance [Source data: 28] 


\subsubsection{Import}

In 2007, Kazakhstan imported $7.2 \mathrm{Bcm}$ of gas. The main suppliers are Turkmenistan with $2.1 \mathrm{Bcm}$, Uzbekistan with $3 \mathrm{Bcm}$, and Russia with $2 \mathrm{Bcm}$ (mainly its own processed gas) [52].

Kazakhstan imports gas from Uzbekistan as part of Gazprom's volume to supply its southern regions, and delivers the same amount of gas produced at the Karachaganak field to Gazprom.

\subsubsection{Export}

Kazakhstan exported $15.2 \mathrm{Bcm}$ of natural gas in 2007. This is practically unchanged compared to the 2006 exports $(15.1 \mathrm{Bcm})$. Almost all of this gas was exported to Russia.

KasRosGas (KRG) a joint venture between Gazprom and KMG operates as the largest buyer and realizes majority of gas exports. Producers sell gas to KRG and KRG handles transit and final sales of gas on the border.

The available gas for export will be around $15 \mathrm{Bcm} / \mathrm{yr}$ in 2010 and reach maximum value of $25 \mathrm{Bcm} / \mathrm{yr}$ in 2015. Russia has already signed a long term contract to purchase, process and sale of $16 \mathrm{Bcm} / \mathrm{yr}$ Karachaganak gas. Kazakhstan, with this agreement, purchased the $50 \%$ of the Orenburg process center in Russia where Karachaganak gas is processed.

In its export policy, Kazakhstan would like to transport the gas where Kazakhstan will obtain profit [53]. In this respect Kazakhstan took into consideration the TransCaspian Export Project (TCP) to find out if the project could meet Kazakhstan's economic interest [54]. But, Kazakhstan Prime Minister Massimov indicated that [56] the US and the EU had not made any special offers to Kazakhstan and Turkmenistan about price and demonstrated to these countries that the investments for transit projects could be lined up soon [55]. This statement maybe was the indication that Kazakhstan was losing its interest toward (TCP). Later on Massimov made clear that Kazakhstan would not participate in the construction of TransCaspian pipeline since it had used its preference for the construction of PreCaspian pipeline [56]. The President of Kazakhstan also made public that Russian direction would remain the most important priority in Kazakhstan foreign policy [57]. 
Kazakhstan does not have excess gas for the additional export to new markets after its agreement with Russia and China. China would like to put gas from the field it is producing to the grand Turkmenistan- China pipeline in Kazakhstan section. European level price negotiation with Russia made Kazakh gas more valuable. The main direction will be Russia.

\subsection{Uzbekistan}

\subsubsection{Reserves}

Proven and Probable gas reserves as of end of 2007 are estimated as $1.8 \mathrm{Tcm}$ [58].

\subsubsection{Production}

In 2007, Uzbekistan produced $65.9 \mathrm{Bcm}$ of gas (Figure 3.12). Uzbekistan plans to produce $66.8 \mathrm{Bcm}$ of gas in 2008 or $2.3 \%$ more than in 2007 . Main producer is Uzbekneftegas (UNG). Russian producer LUKoil is also present with a small production at present.

Russian companies are traditionally active in upstream. LUKoil and Gazprom are involved in Uzbekistan under production sharing agreement.

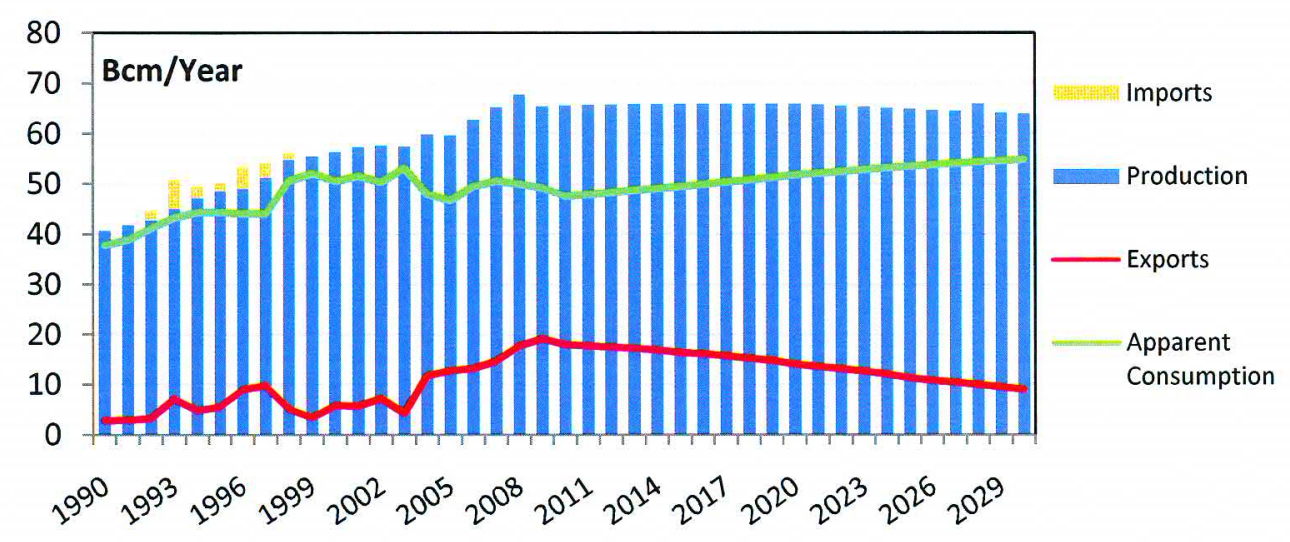

Figure 3.12 Uzbekistan gas balance [Source data: 28] 


\subsubsection{Export}

Although Uzbekistan produces quite big volumes of gas, its larger domestic market makes its export capacity more limited. Uzbekistan exported 14.7 Bcm gas in 2007: $10.5 \mathrm{Bcm}$ to Russia as a main market; and $2.8 \mathrm{Bcm}$ to Kazakhstan; $0.75 \mathrm{Bcm}$ to Kyrgyzstan; $0.65 \mathrm{Bcm}$ to Tajikistan. Uzbekistan is planning to export around $16 \mathrm{Bcm}$ of gas in 2008. UNG will produce over $15 \mathrm{Bcm}$ of the total export gas, while around $1 \mathrm{Bcm}$ will be produced by LUKoil. Of the export volume, over $12 \mathrm{Bcm}$ will be exported to Russia [58].

UNG controls the majority of the country's gas exports. Gazprom is the single authorized buyer of Uzbek gas for export in accordance with the strategic cooperation deal signed in 2002. This deal covers long-term Uzbek gas supply in 2003-2012.

Gazprom has also made an arrangement with LUKoil in 2007 to buy its Uzbekistan production in Uzbekistan border.

In addition, Gazprom participated in the development of transport infrastructure and the transport of Central Asian gas through Uzbekistan. Recently Uzbekistan and Russia agreed to build an extra main gas pipeline that will be parallel to CAC-1 and 2.

Uzbekistan is a high producer. Nevertheless, the export capacity of Uzbekistan due to its gas dependent internal market is low and this export is directed fully to Russia and neighboring Countries.

Uzbekistan, due to political closeness, upstream activities and recent agreement between Russia and Uzbekistan about European level sales pricing will continue to direct the gas to Russia for the future.

\subsection{Turkmenistan}

\subsubsection{Reserves}

Turkmenistan is a significant gas producer and exporter.

According to international estimates, by using all the limited reliable official information, proven and probable reserve is $2.8 \mathrm{Tcm}$ as of end of 2007 [59]. 
But, there is a substantial gap in reserve figure of International estimates and domestic views.

The domestic view shows conflicting numbers. While The Chairman of the Turkmengeologiya State Concern had claimed Turkmenistan's reserve value as $4.97 \mathrm{Tcm}$ in 2005 , today his estimation is $22.4 \mathrm{Tcm}$ gas in place which roughly equals to $17-20 \mathrm{Tcm}$ of gas reserve, assuming the average $80-90 \%$ recovery factor. Internationals guess that $22.4 \mathrm{Tcm}$ gas in place includes yet-to-find resources and think that this leads companies into dangerous path in export planning in advance (59].

Addressing these international concerns, the President of Turkmenistan had ordered in March 2008 an international audit of the country's hydrocarbon reserves in 2008. Results will be known after September 2008.

\subsubsection{Production}

In 2007, Turkmenistan produced $72.3 \mathrm{Bcm}$ of gas (Figure 3.13). Although production is $9 \%$ more than that in 2006 (66 billion cubic meters) it was realized below target volumes. Around $40 \%$ of gas is produced by one field only: the supergiant Dovletabad-Donmez field, rest comes from 50 fields. Turkmengaz National Company produces practically all of the country's gas with the exception of the fields in western Turkmenistan operated by Turkmenneft. Gas production under the Presidents Niyazov and Berdimuhemmedov has been determined as a demand driven. However Turkmenistan could not reach production volume it has planned.

There are a few companies active in upstream side. One of them is PETRONAS, a Malaysian company working on block-1 under Production sharing Agreement (PSA) contract in Turkmen offshore where it discovered gas equivalent to $1 \mathrm{Tcm}$ of reserves, but with un-certified certainty, according to their announcement. PETRONAS is planning to begin commercial gas production from its offshore contract area in 2009/2010. Production infrastructure is being built to process 10 $\mathrm{Bcm} / \mathrm{yr}$ gas that will probably be reached in 2012 . 


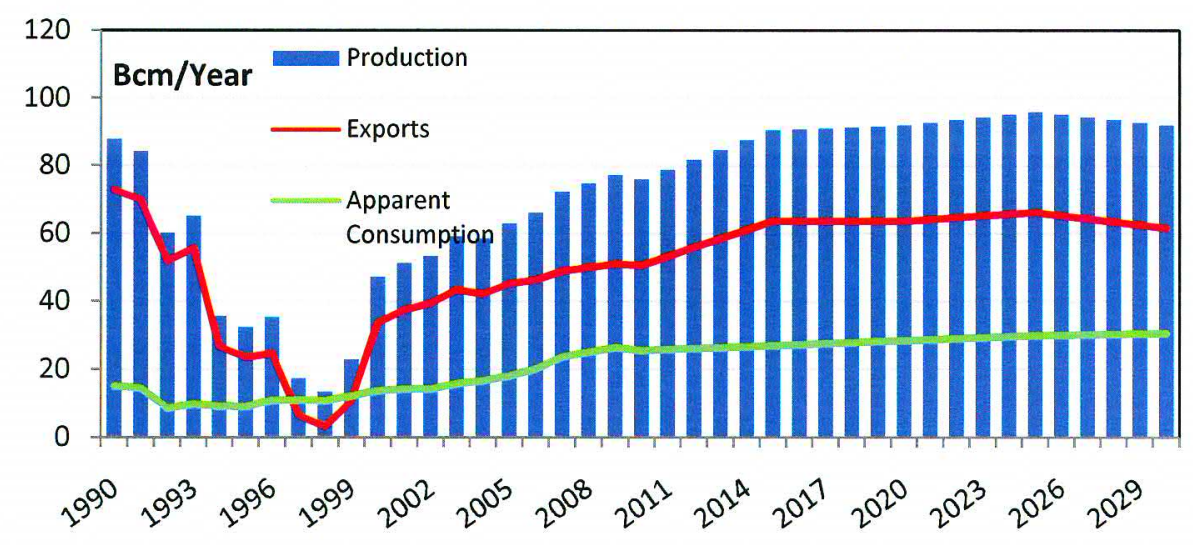

Figure 3.13 Turkmenistan gas balance [Source data: 28 ]

Forecast for Turkmen gas output is predicted to be around $90 \mathrm{Bcm} / \mathrm{yr}$ in 2020's. Although Turkmenistan official figures is much higher than such as the country is aiming at producing $250 \mathrm{Bcm} / \mathrm{yr}$ by 2030 , according to again Turkmen experts [60] the production level can reach $120 \mathrm{Bcm} / \mathrm{yr}$ by 2020 if investment in rehabilitation of current fields and new developments to bring untapped fields into production should be realized. This means that future production will only be able to meet the currently valid contractual commitments of $134 \mathrm{Bcm} / \mathrm{yr}$.

\subsubsection{Export}

According to the Ministry of Economics and Finance, Turkmenistan's gas exports had grown $10 \%$ in 2007 to $51 \mathrm{Bcm} / \mathrm{yr}$ compared to 2006 export volume of 46.4 $\mathrm{Bcm} / \mathrm{yr}$ [59]. The 2006 export volumes correspond to $41.2 \mathrm{Bcm}$ to Russia/Ukraine, and $5.2 \mathrm{Bcm}$ to Iran (Figure 3.14). Turkmenistan's gas export is controlled by Stateown Turkmenneftegas Company.

Turkmen deliveries to both Russia and Iran have been realized below the contractual values.

According to the agreement signed in 2003 , Russia was planning to purchase 70 $\mathrm{Bcm} / \mathrm{yr}$ gas between years of 2007 and 2009 and then up to $90 \mathrm{Bcm} / \mathrm{yr}$ of gas over the next 25 years. However since Turkmenistan had a production difficulty, the contract value for 2007 was revised downward to $50 \mathrm{Bcm} / \mathrm{yr}$. Despite this, export to Russia is confined to $45 \mathrm{Bcm} / \mathrm{yr}$. Turkmenistan export to Russia is via the CAC pipeline series. One reason for the under contracted export might be that the CAC 


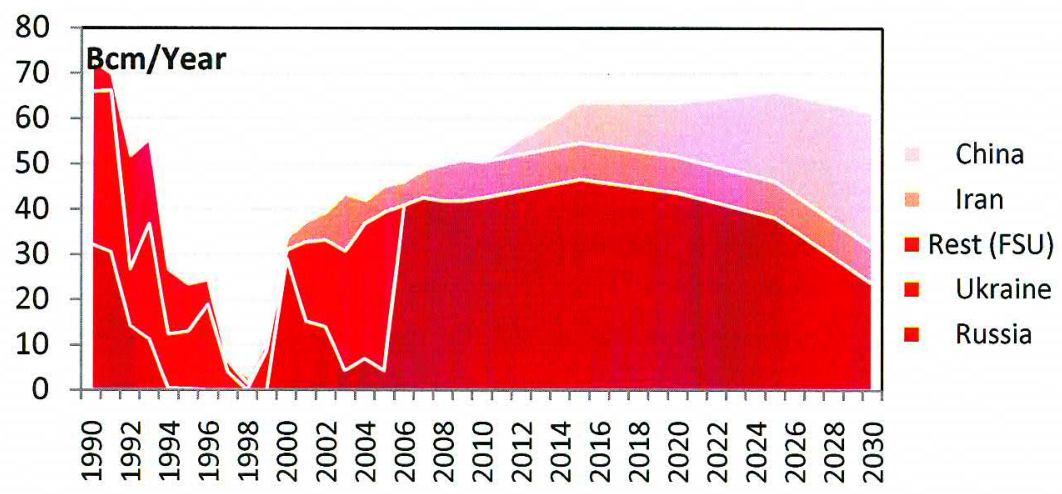

Figure 3.14 Turkmenistan gas export balance [Source data: 28]

pipeline series are severely degraded in the Turkmenistan section and operated under their original capacities. Russia in order to solve the capacity constraint for the future is taking necessary measures. These include major reconstruction along CAC pipeline series to bring capacity up to the original and construction of new pipelines. In this respect Russia, Turkmenistan and Kazakhstan in May 2006 agreed first to renovate the CAC-3 pipeline to bring it its original capacity of $10 \mathrm{Bcm} / \mathrm{yr}$ by 2010 and new construction of PreCaspian Gas Pipeline parallel to the Caspian coast from Turkmenistan via Kazakhstan to Russia to be finished by 2017 with a capacity of 20 $\mathrm{Bcm} / \mathrm{yr}$ [34].

Current export to Iran within 2008 is $9.2 \mathrm{Bcm} / \mathrm{yr}$ [61]. After the meeting between Turkmenistan and Iran in March 2008, export volume is expected to reach the contract value of $14 \mathrm{Bcm} / \mathrm{yr}$. Gas is exported to Iran via the 200-kilometer Korpeje - Kurt Kuy pipeline. Turkmenistan-Iran pipeline has the annual capacity of $14 \mathrm{Bcm}$. The specialty of Iran line is that it is the country's only gas export route that bypasses Russia. It is constructed in 1996 to be the first step of grand Turkmenistan-Iran -Turkey- the EU pipeline to export the Turkmen gas to Europe.

Turkmenistan, in addition to the current export contracts with Russia and Iran, has also commitment for gas exports to China to be started after 2009:

In April 2006, Turkmenistan first, signed a preliminary gas exports agreement with China committing the country to delivery of $30 \mathrm{Bcm}$ per annum for 30 years. The export volume was increased $10 \mathrm{Bcm}$ more to $40 \mathrm{Bcm} /$ Year after the official visit of the President of China Hu Jintao in late August, 2008 [62], second, in 2007 signed the export gas pipeline agreements with China for Central Asia Gas Pipeline 
(SAGP) that is the first large scale gas pipeline bypassing Russia but not a competing pipeline. SAGP linking Turkmenistan with China -- via Kazakhstan and Uzbekistan -- is under construction financed by CNPC and PetroChina with a planned capacity of $40 \mathrm{Bcm}$ per year. The gas for the export to China will be met from the fields that were allocated to China under PSA contract type and from the existing fields. However there is no guarantee to meet all. It is expected that Kazakhstan will also be the potential gas provider to this project.

Pipeline project is sometime developed by strategic reasons even if its capacity is not fully utilized. Once it is operational it is possible for it to benefit from fist-mover advantage and delay additional pipeline capacity, as Chinese companies do in their Turkmen gas project with strong government support.

In the other export attempt, the international company PETRONAS in late 2006 signed a MoU with KazTransGas to transport its gas via CAC-3 [63]. Under PSA type contract the company has a right to market its gas but first, has to establish offtake agreement with Turkmenneftegas. So, PETRONAS will follow the procedure.

Other than the above export projects, there is one important potential project. It is the export of Turkmen gas to Europe. As known, the outlet for Turkmen gas to Europe is either through Iran to Turkey or through Trans-Caspian pipeline (TCP) crossing Caspian Sea to Azerbaijan then to Turkey to be connected to the main artery pipeline Nabucco in Turkey. But, the unilateral American sanction to Iran that prevents Turkmenistan to flow its gas through Iran and unresolved Caspian dispute that is related to the partition of Caspian Sea among its littoral states blocks the project from both directions. Russia and Iran are against the project mainly due to environmental concern [64]. Also, the Kazakh authorities state that the implementation of the Trans-Caspian pipeline is possible only with the consent of all Caspian littoral states [65].Turkmenistan promised to export $10 \mathrm{Bcm} / \mathrm{yr}$ gas to the EU via virtual Trans-Caspian pipeline during the meeting with commissioner for the EU External Relations in April 2008 [66]. However, since there is no infrastructure available, this idea remains theoretical. Project may face difficulty in finding investors since it became extremely politicized. Some ideas [67] such as instead of laying coast-to-coast pipeline in the Caspian Sea, connection of the development fields (specifically Block-1) in the Turkmenistan shelf to the Azerbaijan ACG project offshore infrastructure which at the same time would circumvent Russia from 
protesting is not technically possible. Since the infrastructure capacity of ACG (even for Shah Deniz) is balanced with its production, there is no available capacity for the third party gas and new infrastructure is necessary.

The biggest challenge to TCP project comes from Russia with its existing infrastructure and changing policy in purchase price for Central Asian gas.

As a result of a) agreements signed with Russia, Iran and China that are, with the total volume of $144 \mathrm{Bcm} / \mathrm{yr}$, over its production capacity [68] and these agreements were also confirmed by the President of Turkmenistan Berdimukhemmedov, and b) the hard to solve political natures of the transit routes to Europe, it does not seem any incremental capacity for the EU and the future of export to the EU remains extremely unclear.

\subsection{Iran}

\subsubsection{Reserves}

Iran holds the second largest gas reserves in the world. According to Oil Ministry, it is around $28 \mathrm{Tcm}, 17 \%$ of the world gas reserves. Around $60 \%$ of Iranian gas reserves [69] are located as free gas (non-associated) fields, with $52 \%$ of it located in offshore and $48 \%$ within onshore [70] (Figure 3.15) and have not been developed, implying that Iran has a huge potential for development. Iran's largest non-associated gas field is South Pars with $8 \mathrm{Tcm}$ reserves value and it is the largest complex development project in Iran.

\subsubsection{Production}

In spite of having sufficient proven reserve to supply for both the domestic market and large export markets, Iran has a limited gas production (Figure 3.16) due to two decades of underinvestment combined with internal constraints such as investment terms arising from Constitution and external constraints such as politics and its consequences.

In 2007, Iran produced approximately $100 \mathrm{Bcm}$ sales gas (Figure 3.16) [71]. Sales gas is stabilized around $60 \%$ of gross production. The rest is used as re-injection $(20 \%)$ into oil reservoirs and is flared and lost during process $(20 \%)[70,72]$. 


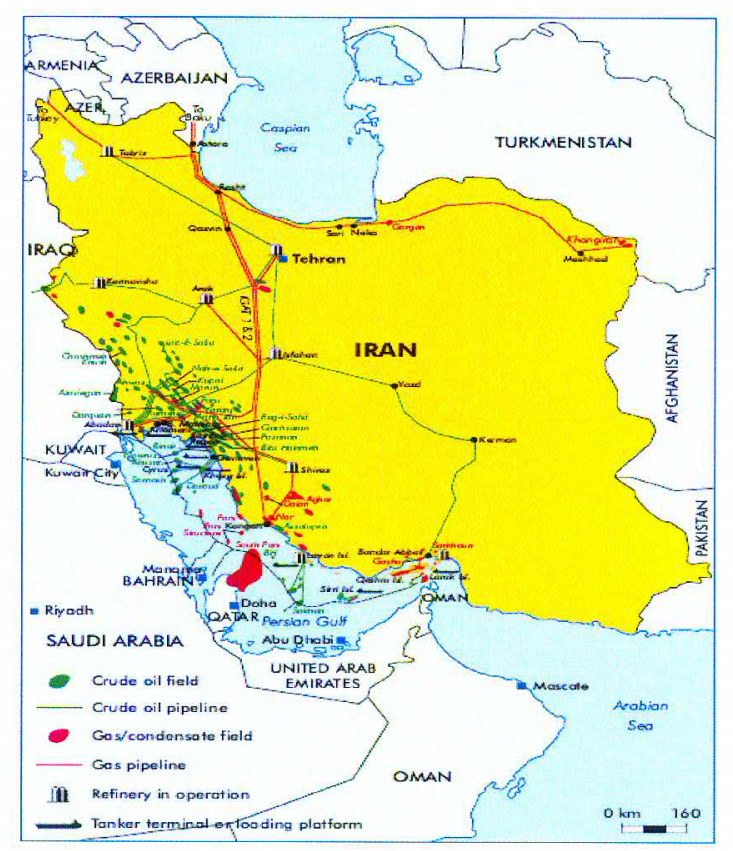

Figure 3.15 Hydrocarbon infrastructure map of Iran [70]

Currently, the rate of growth in development of gas resources does hardly match the rate of increase for internal demand. In 2007, Iran consumed all of the $100 \mathrm{Bcm}$ sales gas it produced [71]. In the future, Iran is set to produce sales gas of $135 \mathrm{Bcm}$ in 2015 and $265 \mathrm{Bcm}$ in 2030 (Figure 3.16).

As indicated above, Iran has internal and external constraints in natural gas development and its utilization that hinder the export potential.

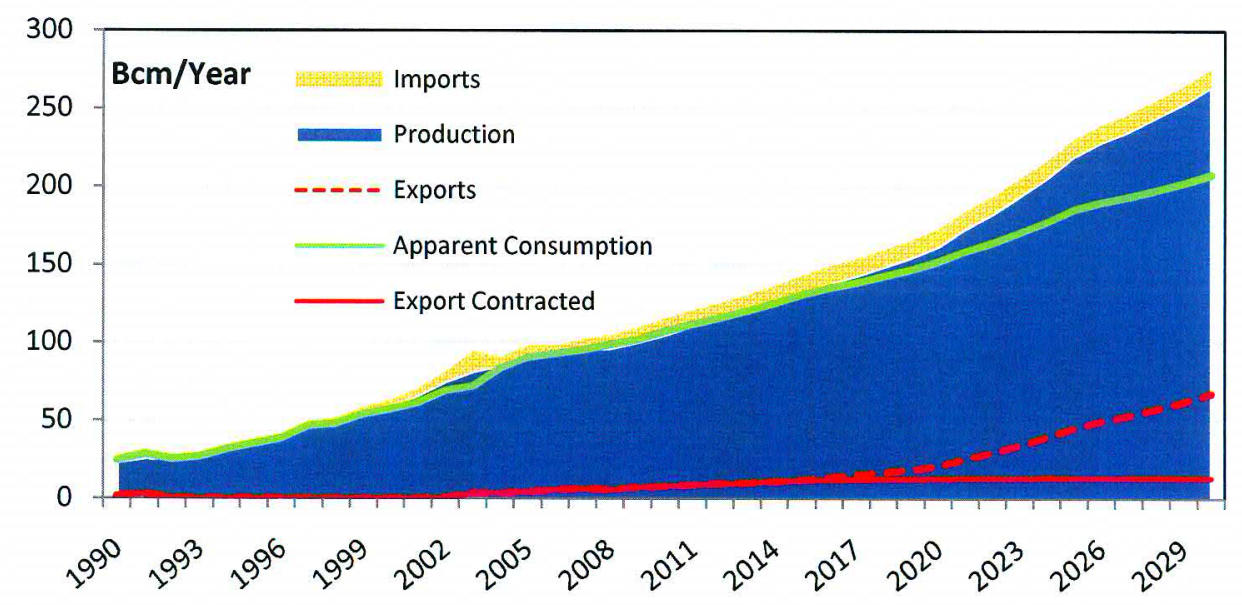

Figure 3.16 Iran gas balance [Source data: 28] 


\subsubsection{Constraints on Development}

\subsubsection{Internal Constraints: The Constitution and Investment Policy}

In Iran the concessionary rights to foreign companies in the Petroleum industry are limited by the articles 81 and 153 of the Constitution. In Article 81, while participation of foreign companies in oil and gas business is allowed, giving concessionary rights to foreign companies are forbidden. And with the article 153 complementing article 81 , foreign controls over the natural resources are forbidden. In this context, in order not to be in conflict with the Constitution, the buy-back (risk-service) contract concept was developed.

In such a contract an oil company (the contractor) carries out exploration and/or development \& production work on behalf of the host country for a fee, namely the host country allows the contractor to recover costs through sale of the oil or gas and pays the contractor fee. Although the fee, in theory, is an acceptable return in the industry practices, there are some important bottlenecks in the contracts: first, investment risks to the great extent are borne by the contractor. Namely, the investment level has to be achieved. If the investment required to produce specified levels of output exceeds specified levels of investment, the contractor has to provide that extra cost. This increases investment risks and lowers the potential return on investment-unless companies build this factor into their original negotiations; second, the contractor from a legal point of view does not have any legal physical ownership, namely since all production belongs to the government, there is no transfer of title in the production and the contractor does not receive any share of production, it gets a share of revenue as a fee.

\subsubsection{External Constraint: Global Politics}

The sanctions imposed by the United States since 1995 deepened the crisis in Iran's petroleum industry. The sanction forbids the US companies from conducting business in Iran and bans any contract for the financing of development of petroleum business. This sanction is also valid for the non-US companies investing more than 20 million $\$$ annually in petroleum industry in Iran. Lately, economic sanctions imposed on Iran by the United Nations Security Council since December 
2006 for its failure to suspend uranium enrichment has also impeded the flow of foreign investment and the entrance of major international companies with experience and high technology, especially in LNG technology that vital process schemes have been patented by the US companies [72]. Today, most foreign financing institutions are reluctant to become involved with the projects in Iran.

This will affect plans as a delay to produce gas in the LNG form from different phases of South Pars in the coming years after major high technology user companies leave the projects. It will be hard for Iran to have this technology and implement it with the companies in Iran which are not experienced in LNG. According to industry analysts, it will take a decade for Iran to develop LNG facilities. The IEA estimates that Iran will need 165 billion\$ to meet its ambitious production plans [73].

\subsubsection{Gas Utilization}

Iran has several options to utilize its gas: domestic household use; industrial use mainly in power generation and petrochemical; gas re-injection into oil fields at least to maintain current production level; and, gas export by pipeline and in the form of LNG. Internal shuffle of gas will be a determining factor for the export.

In domestic use, Iran's energy policy is based on the use of gas and the increase in the share of gas in primary energy. The need to increase gas production to achieve maximum replacement with oil products is continuously emphasized. Target [74] to increase share of natural gas in primary consumption to $69 \%$ in 2009 from $54 \%$ in 2006 was exceeded with the share of $70 \%$ today [75]. Government policy encourages domestic gas consumption with subsidized gas prices to shift away from petroleum (gasoline and diesel) to reduce the need to import refined product of which more than $43 \%$ is imported and to free up oil for export [76]. However, since there is no realistic consumption model, Iran may face to become a major gas importer with the current trend of consumption [75].

In power generation, Iran is facing a tremendous shortfall. It is stated that if Iran cannot solve its energy problem, Iran could cease to be an oil exporter within the next two decade [77]. Although it is said for the oil sector, Iran in order to maintain its oil exporter position will shift to gas. 
In gas reinjection, Iran is allocating a large portion of the produced gas for reinjection purposes. Today $40 \mathrm{Bcm} / \mathrm{yr}$ [78] gas is injected into fields just to keep current oil production. It is expected that in the future this requirement will increase as oil fields will get more mature ("brown field"). According to analysts this figure will be around $100 \mathrm{Bcm} /$ year [79] in the medium term.

In gas export there are conflicting arguments among the policy making in the government. While one group supports that all gas production should go to domestic consumption and re-injection into oil fields for economic interests, the other group argues that reserves are sufficient to allow for export and that although priority is given to domestic consumption and re-injection Iran must not abandon gas export strategy in view of longer-term economic and strategic interest. But, the base scenario (Figure 3.16), the forecast of IEA [70,72] and the western consultants [79] agree that natural gas exports will be minimal due to rising domestic demands, insufficient investment and technology.

\subsubsection{Import}

Iran in order to meet the demand in northern areas, far from the country's main gas reserves located in the south (Figure 3.15), has been importing gas from Turkmenistan since 1998. In 2007, 6.4 Bcm gas was imported from Turkmenistan, approximately $6.4 \%$ of total sales gas consumption (100 Bcm/yr). This volume increased to $9.2 \mathrm{Bcm} / \mathrm{yr}$ in the beginning of 2008 and will be restored to gradually to contract value of $14 \mathrm{Bcm} / \mathrm{yr}$ by Turkmenistan.

Since the volume of surplus gas is very low, continuous flow of import gas gains importance especially for residential use during winter time and for export to Turkey.

\subsubsection{Export}

Although consumption is growing rapidly and gas balance is tight, Iran continues to promote export markets for its natural gas. Presently Iran holds three small natural gas export contracts with neighboring countries: Turkey, Armenia and Azerbaijan. 
According to the contract signed in 1996 with Turkey, export for 26 years was inaugurated in 2001 at the initial rate of $3 \mathrm{Bcm} / \mathrm{yr}$. Export volume reached average 6.2 Bcm/yr in 2007 and it is expected to come to the contract plateau value of 10 $\mathrm{Bcm} / \mathrm{yr}$ in 2010. Export is realized via Iran-Turkey gas pipeline constructed between Tabriz and border city of Bazargan. This pipeline links Iran to Ankara via Erzurum [92].

According to the agreement, Armenia is to receive up to $0.4 \mathrm{Bcm}$ gas per year, with further increases of up to $2.3 \mathrm{Bcm} /$ year in return for electricity as planned. Export to Armenia is expected to start in October 2008 via new regional Iran-Armenia gas export pipeline that its construction was completed in 2007[71].

A 20-year gas-swap agreement is in place with Azerbaijan receiving gas at the Astara border for delivery at the Jolfa border, Nakhichevan. It has been operational since 2005 but quantities are limited to $300-500$ million $\mathrm{cm}$ per year. Iran receives a proportion (about 13\%) of the gas as transit fees.

Besides Turkey and Armenia, Iran, with two options, pipeline gas and LNG, is trying to improve export possibilities.

In this respect, through pipeline projects Iran plans to explore regional markets: To Pakistan and India in the East through planned Iran-Pakistan-India (IPI) projects of total $2775 \mathrm{~km}$ in length with ultimate capacity of $55 \mathrm{Bcm} / \mathrm{yr}$; To Europe in the west via the Fourth Corridor pipelines starting in Turkey; And to the neighboring gulf countries Kuwait, United Arab Emirates, Oman, and Bahrain. The east and west directions are in the zone of political risks.

Within the plan of exporting gas to the West, American led sanctions and lately the UN sanctions started in 2006 divided international community on working with Iranian petroleum industry. For instance, while companies such as ElektrizitatsGesellschaft Laufenburg AG (EGL) of Switzerland with whom Iran concluded a sale and purchase agreement in June 2007 and ratified in March 2008, and some countries like Turkey are positive for trading with Iran for the European market, the EU ruled out the supply of Iranian gas as long as political uncertainties continued.

Through LNG, Iran makes its plans globally to capture an estimated10-12\% of LNG market in Europe and Asia-Pacific by 2015 [80]. For this purpose, phases 11,12,13 and 14 of South Pars field have been allocated for the three LNG projects with the 
total capacity of $60 \mathrm{Bcm} /$ year (44 Mton/yr) (3.60): Pars LNG with Total of France and PETRONAS of Malaysia; Iranian LNG with Shell of Holland and Repsol of Spain; Persian LNG with Local companies of Iran. Unfortunately TOTAL, Shell and Repsol pulled out of projects due to technical and political reasons. Despite the statements of Iran that it intends to continue with its LNG projects by itself, the financial and high technological deficiency will not let Iran to pursue the mentioned intention.

Iran now is seeking to use the LNG processing facilities in Oman to export the gas. This approach is also positive for Oman who is suffering from a shortage of gas for its LNG project. Gas for this project will be supplied by 2012 from Kish field which is to be developed jointly by Iran and Oman [81].

It is likely that the gas export project to the EU is ruined by Iran's political isolation. The export opportunities might only be materialized if Iran resolves the nuclear enrichment issue in a peaceful way. In addition, the internal domestic policy for the utilization of natural gas is another constraint to solve the bottleneck in gas export. For today, due to insufficient gas production and political reason, Iran is not in an exporter position.

\subsection{Iraq}

\subsubsection{Reserves}

Iraq has free and large associate natural gas reserves of $3.17 \mathrm{Tcm}$ [7] located in the north and south of country. While the reserves in the north are composed of mainly non associated and associated gas, reserves in the south are mainly associated gas and represent the bigger part of source (Figure 3.17).

\subsubsection{Production}

Figure 3.18 shows [82] the associate gas production and its utilization corresponding last years. The gross gas production is around $13.5 \mathrm{Bcm} / \mathrm{yr}$. Sale gas represented $1.46 \mathrm{Bcm} /$ year. According to the Iraqi Ministry of Oil [83], 


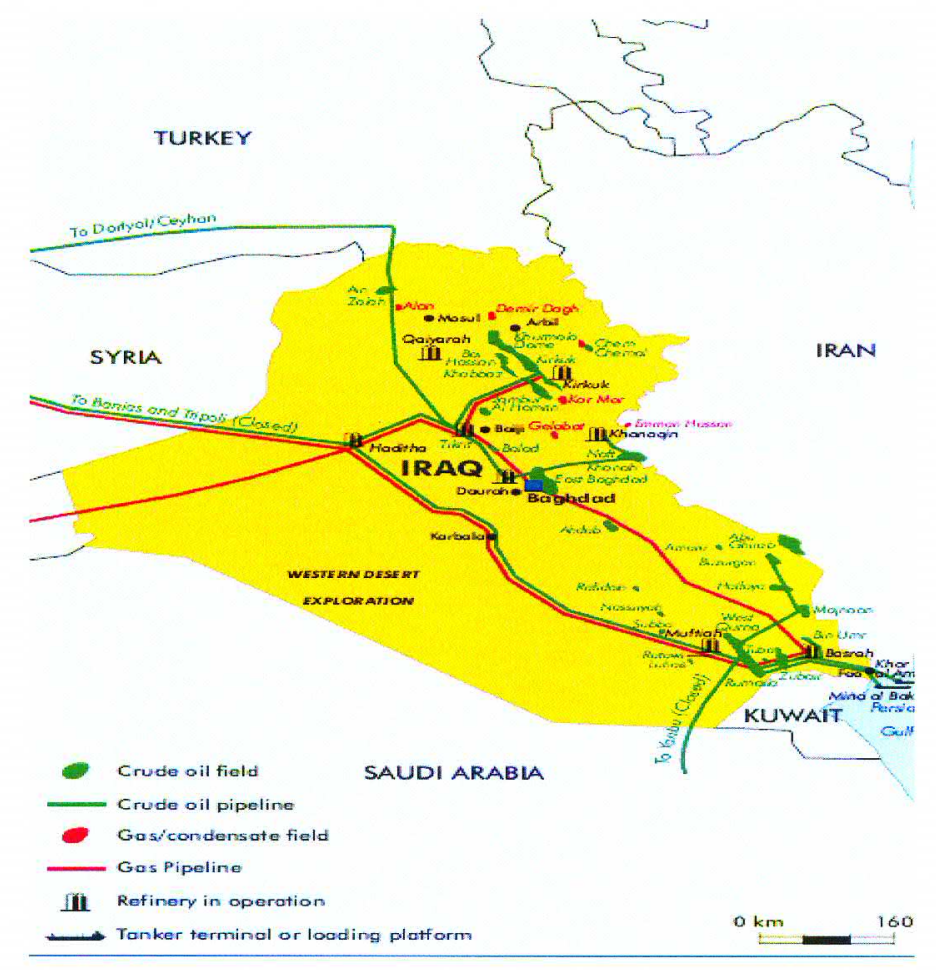

Figure 3.17 Hydrocarbon infrastructure map of Iraq [70]

The majority of gas production comes from the Southern part of Iraq with 10.4 $\mathrm{Bcm} / \mathrm{yr}$. Approximately $6.5 \mathrm{Bcm} /$ year of associated gas was flared. Of this 6.25 $\mathrm{Bcm} / \mathrm{yr}$ belongs to South.

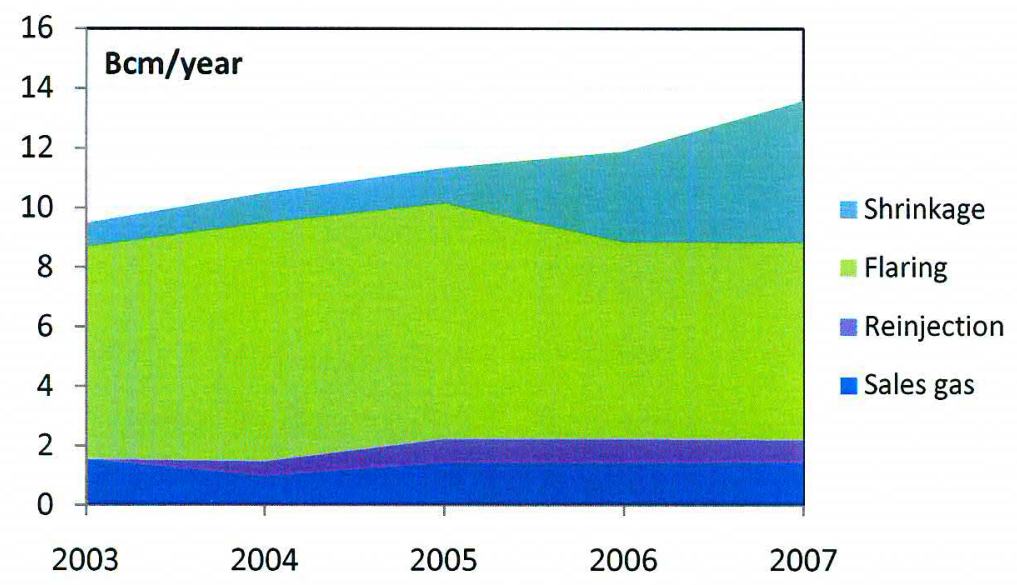

Figure 3.18 Iraq gas balance realization for last five years [Source data: 82 ] 


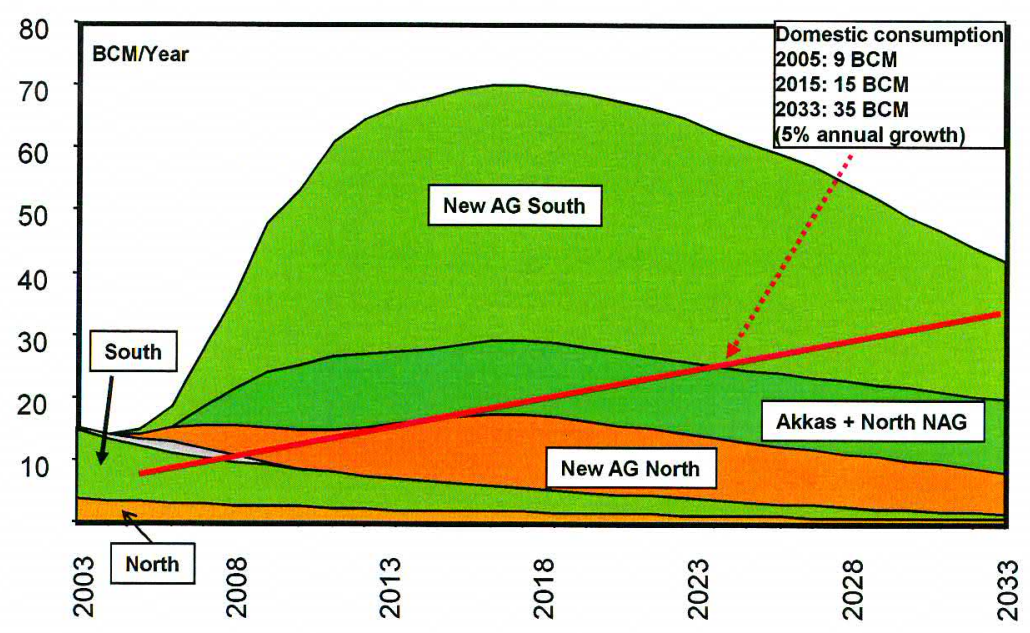

Figure 3.19 Iraq gas balance [84]

\subsubsection{Export}

Figure 3.19 shows the long term production and export potential [84]. Realization of this figure will depend on the full utilization of Iraqi free gas and oil fields. However, due to security issues in the county it will not be possible to reach that level at its original time scale.

Iraq is trying to develop its export possibilities in three directions.

In order to bring into exercise: the first possibility is that Shell recently in January 2008 met with Iraqi officials to utilize the free and associate gas of southern Iraq, where also about $6 \mathrm{Bcm} / \mathrm{yr}$ of associated gas is being flared from oil fields, to meet energy demand in southern Iraq firstly and neighboring Gulf and Middle Eastern countries secondly where gas demand grew 28 percent from 2003 to 2006 as the United Arab Emirates and Saudi Arabia developed steel, aluminum and chemical industries to curb their reliance on crude oil exports [85]. Shell would also build a facility that could freeze 16 million cubic meters of gas a day and ship it to Kuwait and the United Arab Emirates. As this thesis was being completed, it was reported that Shell and Iraq signed the agreement to realize this aim.

The second possibility is that the European Commissioner for External Relations, Benita Ferrero-Waldner, and the European Commissioner for Energy, Andris 
Piebalgs, met in Brussels with the Minister of Oil of the Republic of Iraq, Hussain AlShahristani, in February 2008 [86], to discuss enhancing energy cooperation between the European Union and Iraq. In this context, Parties agreed to work together on the development of interconnections of Iraq's gas infrastructure to the Arab Gas Pipeline which will supply the EU through the Nabucco. As a first step Akkas field (4 Bcm/yr of potential production rate) is a candidate to be developed to meet Syria's domestic demand and then to be connected to Arab pipeline in Syria.

The third possibility is that Oil Ministry of Iraq announced development works of Mansuriyah gas field ( $3 \mathrm{Bcm} / \mathrm{yr}$ of potential production rate) through international tender which, once upon a time, was the main part of Iraq-Turkey gas export project. Oil Ministry's opinion about possible export route for that field is to be via Turkey. However, this writer thinks that, stand-alone development of this field and bringing its gas to Turkey with a new pipeline to be connected to the Nabucco is not feasible at all. This field, if it is really developed for export, is likely to be directed to Syria via the Akkas field infrastructure.

Under the light of from these developments: First, there will be a considerable decrease in the volume of potential gas to be exported to Europe via Turkey since the majority of gas is located in the southern Iraq; Second, connection of small scale Iraqi gas to Turkey indirectly through Arab pipeline via Syria will lessen Turkey's position considerably as a juncture point.

In Iraq the nature of the contract will be a service contract type. Even the PSA type contract signed under Saddam Government in 1997 with China was transformed into a service contract after the renegotiations with China in September 2008 [103]. Through service contract, the expenses to the investor will be paid as a fee rather than hydrocarbon and export will be under control of Iraq. 


\section{CHAPTER 4}

\section{STATEMENT OF PROBLEM: TURKEY AND ITS OBJECTIVES}

Diversification of gas sources and routes are the keys for the Europe's energy security. Although current suppliers Russia, Norway and Algeria will keep their positions as principal suppliers, the Caspian, Central Asian and Middle Eastern countries with their vast natural gas sources are potential alternative targets for the EU. On the one hand, supplying Europe with the above alternative sources to relieve Europe of overdependence on Russia is in the interest of the EU and the US through developing secure cross-border transit routes to Europe. Within this context, Turkey with its geographical position has been considered as a transit country for natural gas to Europe. On the other hand, Russia by taking into consideration the Soviet legacy and its energy policy would like to maintain its quasi-(natural) monopolistic behavior in developing the region and in keeping its sole transit country status.

The question here is whether or not Turkey will be able to accomplish to become a transit gas hub country. This brings into mind a question of how deeply Turkey will involve in developments in this issue.

In this chapter Turkey's strategy was evaluated by taking into consideration the developments in the region on the one hand and strategic visions of Turkey versus internal dynamics such as quality of bureaucratic elites on the other hand.

\subsection{Turkey's Gas Policy}

The gas strategy of Turkey is multi-dimensional. Turkey, on the one hand, for its expanding gas need, pursues policies to ensure diversified, reliable and costeffective supply sources. On the other hand, she would like to become a major transit (Figure 4.1) and trading hub in the region. According to the estimations, Turkey expects to transport up to $100 \mathrm{Bcm} / \mathrm{yr}$ gas to Europe by 2020 (Figure 4.2) $[87,88]$. 


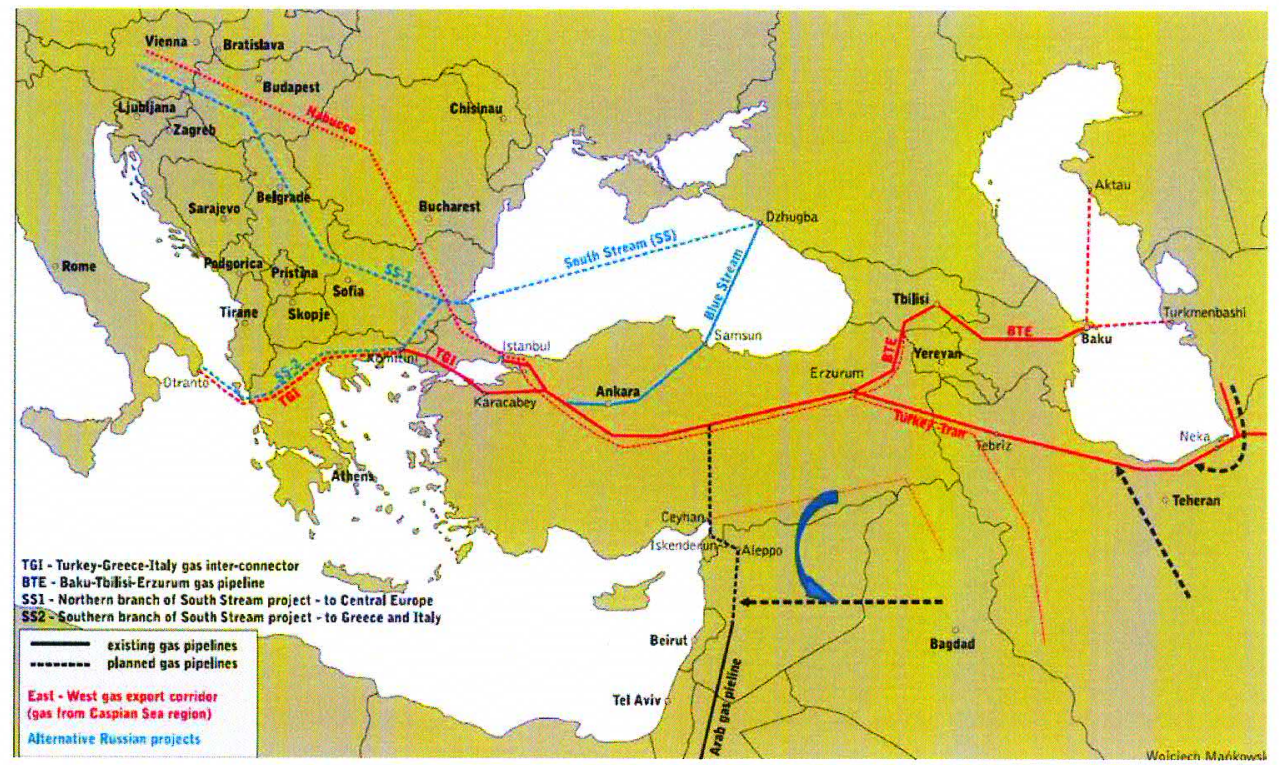

Figure 4.1 The Fourth Corridor [89]

The Ministry of Energy and Natural Resources, BOTAS, and to a small extent, Ministry of Foreign Affairs are committed to developing Turkey as a transit hub for natural gas, aggregating gas from the Caspian and the Middle East and forwarding this through pipeline series to southern or south-eastern Europe (Figure 4.1). In order for this ambition to be realized, a) the EU's point of view, b) export potential of surrounding producers, and c) Turkey's gas demand supply balance and its internal gas infrastructure capacity to transit are the key elements.

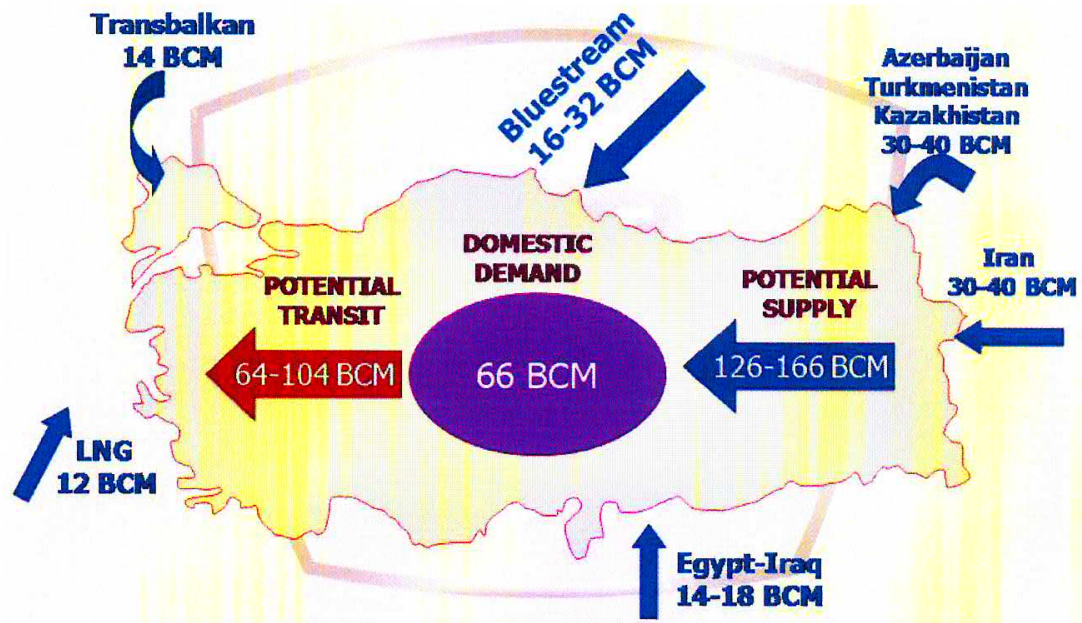

Figure 4.2 BOTAS's export/transit scenario for Turkey [87] 
In chapter 2, it is observed from the EU's point of view that the EU made itself clear with its official documents about realizing the Fourth Corridor. However, although Turkey has a fundamental importance as an alternative transit country, in the implementation of this project transportation /transit terms gains importance from the supplier/consumer point of the view.

In chapter 3, the export potential and export direction of the producers was analyzed in general and it is concluded that there will not be any considerable amount of gas flow via Turkey to make Turkey a major transit gas hub country. However in this chapter the regional gas export pipelines potentially directed toward Turkey will be described from Turkey's point of view.

Before going further into the gas balance and infrastructure, below, the actors in energy in Turkey are described.

\subsection{Internal Dynamics: Policy Bodies}

The Turkish authorities are fully aware of the gas supply security due to increasing import dependency and have been working to secure the dependency. At the same time they are involved in guaranteeing Turkey's position as a transit hub / trading hub. However, to realize this vision, there are some limitations to overcome. These limitations are illustrated by the case studies in the description of institutions in policy making (Figure 4.3).

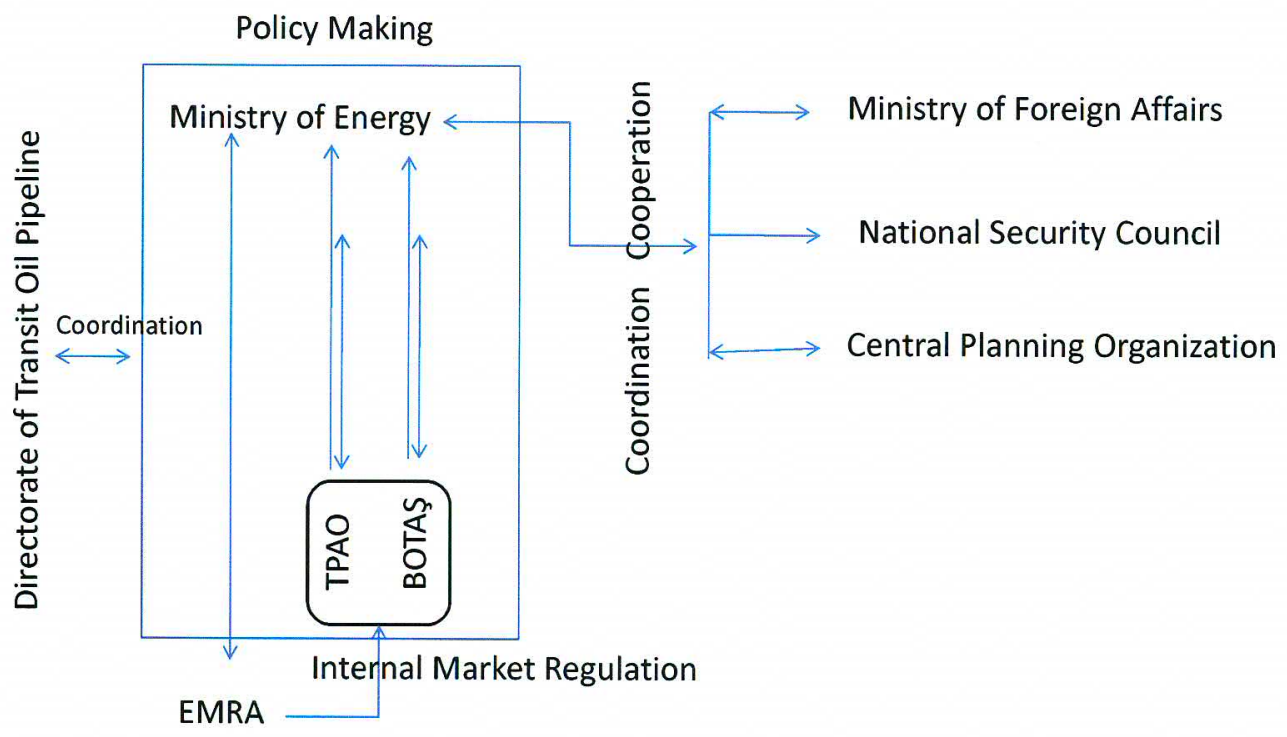

Figure 4.3 Policy bodies 


\section{The Ministry Of Energy and Natural Resources (MENR)}

MENR was established in its present form in 1963 to develop the energy resources of the country. Its duty is to play a key role in the development and implementation of policy. Some of the tasks of the Ministry are; to control and monitor the activities related to energy development; to coordinate issues of trans-border pipelines; and lately to participate in contract negotiations with countries exporting natural gas and electricity.

In drawing the policy and its analysis and implementation in the oil and gas sector; Directorate for International Affairs and Directorate for Transit Oil Pipelines as a main departments within the Ministry; and Turkish Petroleum Corporation, TPAO and Petroleum Pipeline Corporation, BOTAS as related companies play roles at different strength.

MENR reports to both the Council of Ministers and the National Security Council, for issues of energy security and diversity of supplies. The National Security Council, or MGK (Turkish abbreviation), is an influential body.

MENR also co-operates with the Ministry of Foreign Affairs (MFA) on energy security and cross-border pipeline projects. Currently, overall responsibility for the Turkish energy sector lies with the Ministry of Energy and Natural Resources.

The coordination and cooperation more importantly consistency in the policy objective between departments / companies under the Ministry and office of minister is essential to pursue an effective external policy. However, it is somewhat hard to see these characteristics. The individual views to a large extent are the determining factor.

The Agreement signed in July 2007 with Iran regarding the field development in South Pars by TPAO is a good example to show a lack of coordination and cooperation between the Ministry and TPAO. The relation with Iran in this respect was initiated by the Advisor(s) to the Minister, who has (have) no knowledge in the harsh working conditions in Iran and about the capacity of TPAO to accomplish such a challenging offshore project, without consulting (even without informing) TPAO.

The Ministry a long time after the MoU was signed realized that its terms were complex and admitted that Turkey took a serious risk. 
Strategic vision of the Ministry and the quality of the actors in energy decision making should be in harmony if the Ministry wants to fulfill a meaningful task in the region.

\section{The Petroleum Pipeline Corporation (BOTAS)}

BOTAŞ who is a state-owned oil and gas transport and trading company was founded in 1974 first to transport oil and since 1984 it has been engaged in wholechain gas business under Decree 397 that established the importation, distribution, transmission, sale and the pricing of natural gas under the responsibility of BOTAS. The above monopolistic structure of BOTAS was ended by the Natural gas Market Law 4646 in 2001 with the aim of introducing liberalization and competition into the Turkish gas market.

BOTAS now is in target under the Natural Gas Market Law of 2001, to be unbundled for privatization of its gas trading and wholesale activities other than transmission to be within state control. BOTAS is subject to the control of the Ministry of Energy to regulation by EMRA. The Regulator requires it to unbundle its activities in line with the Natural Gas Market Law and has to approve its transmission charges (still to be clarified) and sales tariffs.

As of today, BOTAS was barred from importing piped gas to be consumed in Turkey until its share of gas imports falls below the $20 \%$ of total import. The exception is the gas to come from Egypt on the condition that there will be supply gap at the time BOTAS wants to import.

BOTAS, also under mandatory release program, should transfer imports rights in its portfolio until its import share falls below $20 \%$ by 2009 . So far, BOTAS has only released $4 \mathrm{Bcm} / \mathrm{yr}$ of the import contracts to the four companies under the contract transfer program and has well behind the release program. To overcome the delay, it was announced by the EMRA that there would be a change in the rules of contract release.

\section{The Turkish petroleum Corporation (TPAO)}

TPAO is state-owned upstream Exploration and Production Company. TPAO started its international activities in Kazakhstan in the early 1990s. In the first years of independence of the Caspian countries (first wave), TPAO managed to enter into 
upstream development activities in Azerbaijan in the ACG and Shah Deniz Projects operated under BP leadership and later on into midstream activities in BTC and SCP pipeline projects as a shareholder. TPAO today has an exploration activity in Libya in addition to above stated activities. However, TPAO, so far, has achieved a limited level of success.

According to the Ministry of Energy sources and lately to BOTAS, if Turkey wants to be a player and turn itself into an energy trade center, it has to be more active in the Caspian region and that includes buying fields.

Turkey in the first wave, due to its strong geostrategic relations and strong cultural ties with Turkic Republics, received a stake in Azerbaijan and Kazakhstan. But in fact it was an exception for Turkey. Today, this is not sufficient anymore to be recognized as a player in the petroleum industry. Economic and technological prowess has been the determining criteria. From Algeria to Iraq, Iran, and Turkmenistan and to Kazakhstan, Producing countries want to cooperate with wellknown companies with high experience especially in development, production and high technology. Not being qualified by the Ministry of Oil of Iraq in April 2008 to bid for future oil and gas contracts in Iraq as a result of major lack of experience is a fresh example for Turkey. The later attempt to include Turkey into the qualified company list never changes the place of TPAO in the eyes of Iraq. This has been evident when Prime Minister signed the last minute agreement in Iraq on July 12 , 2008. Agreement only allowed TPAO to enter into Iraq just as a shareholder within a consortium.

In that sense, a frail TPAO (It is appropriate to remind that the weakness is also valid for BOTAS too, considering the Iraq -Turkey gas export project, BOTAS could not do well) has kept Turkey from carrying out an assertive energy dialogue with producer countries.

The weakness of TPAO is a product of its internal dynamics. Poor human-resources management and ineffective manpower and increasing, explicitly since 2003, interdisciplinary conflict which can be defined as an internal power struggle in order to manage the company, and heavy Ministerial interference externally in addition have strangled the TPAO's productivity. 
Unless necessary steps are taken, these wasteful practices will continue to be problems needing solutions.

\section{The Ministry of Foreign Affairs (MFA)}

MFA in general runs energy matters through the Deputy Directore General for Energy, Water and Environment within the Ministry. The Ministry is considered as a coordination body and it has a consistent policy. However, frequent changes (2-3 years) in the personnel assigned to certain tasks create a break in the flow of the implementation of policies within steady quality.

\section{The Undersecretariat of Treasury}

It is involved in the guarantees which it assigns to the performance of state bodies such as BOTAS.

\section{The State Planning Organization}

This body, which reports to a State Minister, is charged with ensuring the optimum allocation of investment resources. As remembered this organization had long challenged MENR's forecasts regarding natural gas demand scenarios and lack of project prioritization in the late 1990 s.

\section{The Energy Market Regulatory Agency (EMRA)}

EMRA established on May 2, 2001, following the enactment of the Natural Gas Market Law 4646, is authorized to and responsible for regulating the gas and electricity and product markets. Among its duties are setting system access tariffs, examining and approving plans for investment in the transmission system, monitoring importation, transmission, distribution, storage, trade and exportation of natural gas to ensure their compliance with the Natural Gas Market Law. Supply/Demand is also authorized by EMRA. EMRA is not included in the decision process in external energy strategy [90]. 


\subsection{Demand and Supply: Gas Balance}

With its emerging and rapidly growing economy, Turkey is facing a rising growth in its demand for gas. In 2007, the gas demand of Turkey was realized as $36.5 \mathrm{Bcm}$ [91], and due to the very low domestic production $(0.8 \mathrm{Bcm} / 2007)$ nearly all of demand was imported (36.4 Bcm/yr), through BOTAS, the state own Oil and Gas transportation Company, from Russia, Iran and Azerbaijan via pipeline, from Algeria and Nigeria in the form of LNG. Import is mainly concentrated on Russia (Figure 4.4).

From now on BOTAS and 4 new importers presently, and more at the later years as release programs are realized, are designated as the importers.

Turkish gas demand is expected to increase from $37.5 \mathrm{Bcm} / \mathrm{yr}$ [90] in 2008 to 76 $\mathrm{Bcm} / \mathrm{yr}$ [91] in 2030 (Figure 4.4). As seen from the Figure 4.4 there are two demand scenarios by the MENR [92] and BOTAS [91]. It is not clear from where these differences come from but they might rise from the possible contribution of nuclear energy expected to be started in 2012. Since it is not known when it will actually be introduced, the forecast of BOTAS is taken into account in this section.

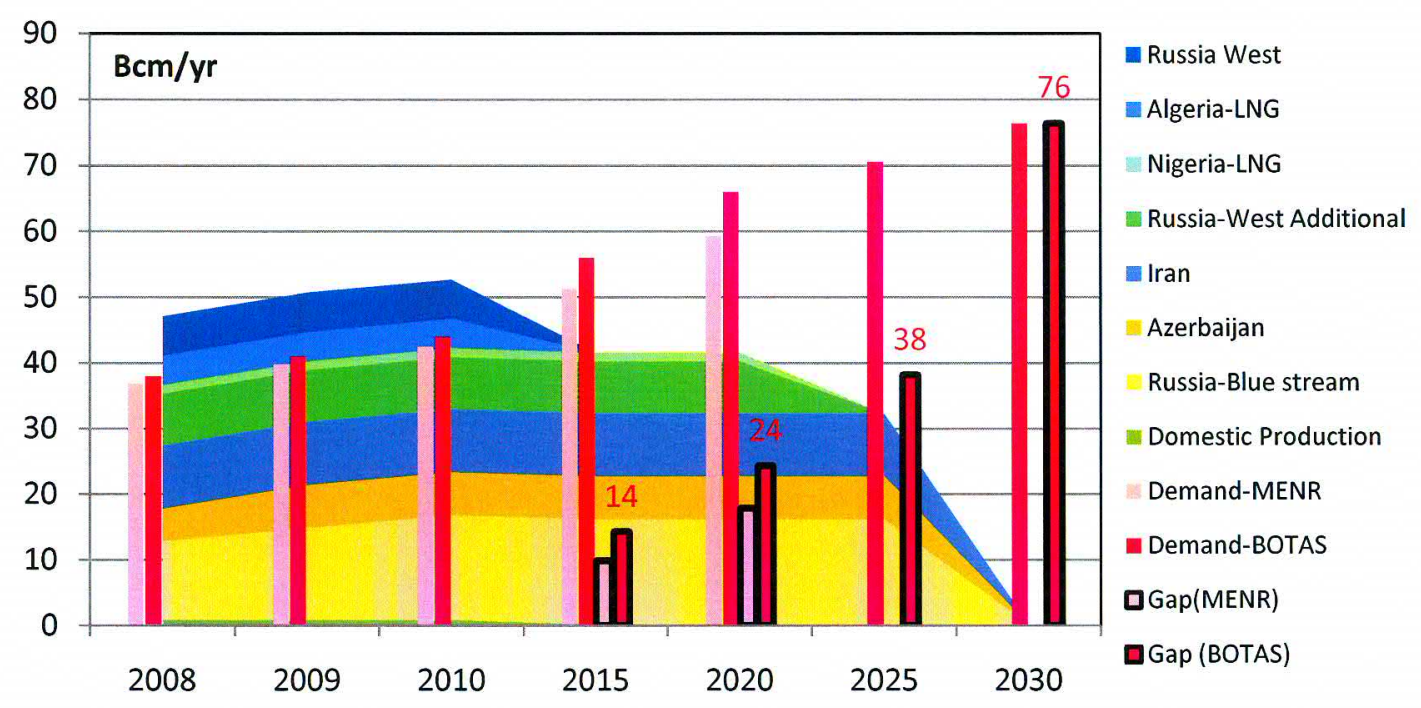

Figure 4.4 Turkey gas balance [Source data: 91, 92]

Through the figure, although it is understood that Turkey is oversupplied with its contractual volumes presently, volume of physical flow of gas actually is making 
demand and supply balance tight. With the expiration of Russian-West supply of 6 $\mathrm{Bcm} / \mathrm{yr}$ and Algerian LNG of $4.44 \mathrm{Bcm} / \mathrm{yr}$, Turkey will face deficit before 2015 . Considering these contracts will be renewed when they expire, Turkey's deficit is likely to be $4 \mathrm{Bcm}$ in 2015, $15 \mathrm{Bcm}$ in 2020 and $28 \mathrm{Bcm}$ in 2025. Even if it is assumed that all the current contracts will be renewed, Turkey inevitably will face a deficit of minimum 4 Bcm/yr before 2015, 14 Bcm/yr in 2020 and 18 Bcm/Year in 2025. Turkey is likely to secure its needs under market conditions before it releases the potential gas to the EU. At the first place, Turkey will try to secure $9 \mathrm{Bcm} / \mathrm{yr}$ of the deficit via Egypt with $4 \mathrm{Bcm}$ and via utilizing the idle private LNG regasification terminal with a capacity of $5 \mathrm{Bcm} / \mathrm{yr}$. the rest of deficit $5 \mathrm{Bcm} / \mathrm{yr}$ will be met by other sources in the future.

Related to the supply, there are two constraints at the moment to secure the gas, establish local trading center and to develop competition for the Turkish market. These are:

Both new importers and BOTAS are prohibited to sign new pipeline contracts (there is no restriction for LNG) for Turkey's domestic needs with BOTAS's existing suppliers.

Import right except for transit flow of gas via Turkey is given to a company if there is a gas deficit in the forecast determined by EMRA. This is an indication of tight supply and demand balance.

\subsection{Infrastructure: Existing and Proposed Future Gas Pipelines}

Turkey with its current pipeline network in operation (Figure 4.5) and potential future international pipeline series is preparing itself to be the Fourth Corridor.

\subsubsection{Existing Pipelines and LNG Regasification Terminals [91]}

\section{Trans-Balkan Import Pipeline}

It comes from Southern Russia via Ukraine, Moldavia, Romania, and Bulgaria to Turkey. The nominal capacity of its Turkey entrance is $16 \mathrm{Bcm} / \mathrm{yr}$ and current transported volume is $13.8 \mathrm{Bcm} /$ year. 


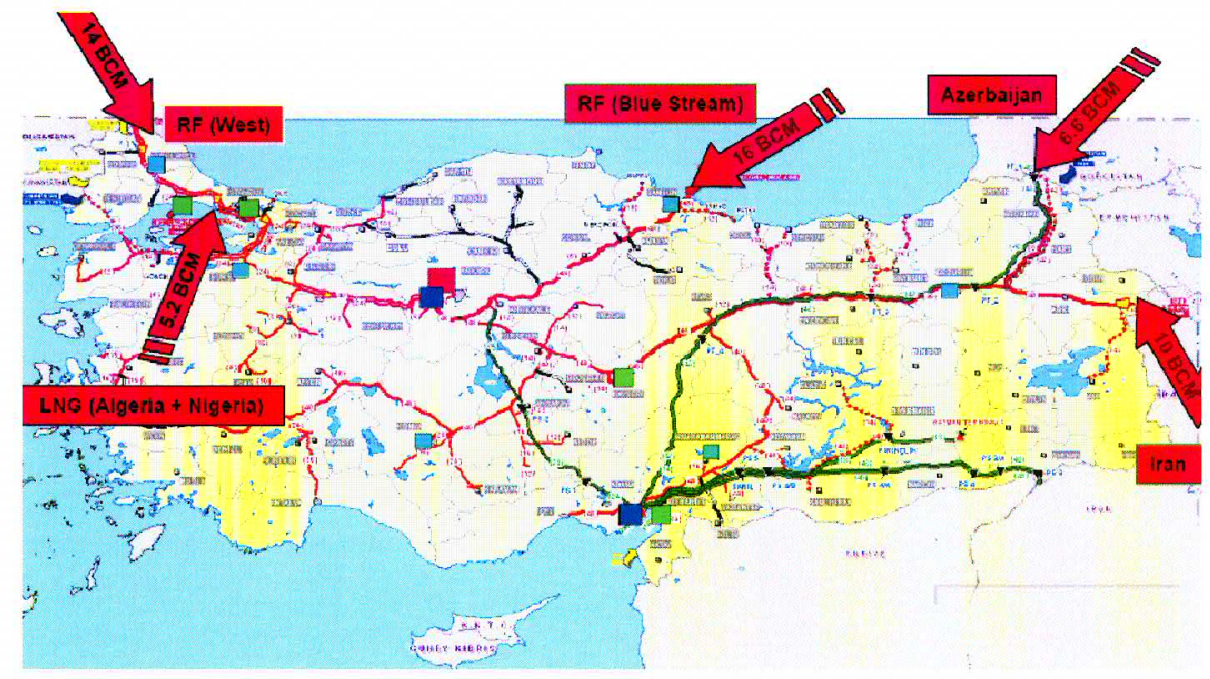

Figure 4.5 Turkey gas transmission infrastructure [91]

\section{Blue Stream Import Pipeline}

It is a direct pipeline from Russia to Turkey crossing the Black Sea with a nominal capacity of $16 \mathrm{Bcm} / \mathrm{yr}$. Current transported volume is $9.3 \mathrm{Bcm}$

\section{Georgia - Erzurum Import Pipeline}

It receives Azerbaijan gas and it is the continuation of the newly constructed South Caucasus Pipeline (SCP) running from Baku, Azerbaijan to Georgia-Turkey border. This pipeline is also named as Baku-Tbilisi-Erzurum (BTE) Gas Pipeline. Its present capacity is $8 \mathrm{Bcm} / \mathrm{yr}$ to carry Shah Deniz phase I gas. Present capacity with the increasing gas volume can be increased to $22 \mathrm{Bcm} / \mathrm{yr}$ with the additional compression investment. Currently it transports $3.5 \mathrm{Bcm} / \mathrm{yr}$ and expected to reach $6.6 \mathrm{Bcm}$ until 2010.

\section{East Anatolian Main Transmission Pipeline}

It carries gas from Iran to Ankara, Turkey with the present capacity of $10 \mathrm{Bcm} / \mathrm{yr}$ but has a capacity to be increased to $20 \mathrm{Bcm} / \mathrm{yr}$. Current transported volume is 6.2 Bcm/year. 


\section{Turkey Greece Export Interconnector}

This is an export pipeline to supply gas to Greece. Pipeline is also the first part of Turkey-Greece-Italy interconnector (TGI), supported by the EU within the Fourth Corridor concept. It has $12 \mathrm{Bcm} / \mathrm{yr}$ capacity. Currently, this line carries BOTAS reexport of $0.75 \mathrm{Bcm} / \mathrm{yr}$ Azeri gas.

Table 4.1 Turkey main gas transmission network capacity, Bcm/yr [Source data: 91]

\begin{tabular}{|l|c|c|c|c|}
\hline & $\begin{array}{l}\text { Existing } \\
\text { Capacity }\end{array}$ & $\begin{array}{l}\text { Potential } \\
\text { Capacity with } \\
\text { Enhancement }\end{array}$ & $\begin{array}{l}\text { Current } \\
\text { Flow }\end{array}$ & $\begin{array}{l}\text { Capacity } \\
\text { To Be Filled }\end{array}$ \\
\hline Trans Balkan Import Line & 16 & 16 & 13,80 & 2,20 \\
\hline Blue Stream Import Line & 16 & 16 & 9,30 & 6,70 \\
\hline East Anatolian Import Line & 10 & 20 & 6,20 & 13,80 \\
\hline BTE Import Line & 8 & 22 & 6,60 & 15,40 \\
\hline Turkey Greece Export Line & 12 & 12 & 0,75 & 11,25 \\
\hline
\end{tabular}

In addition to the pipeline network, Turkey has two LNG regasification terminals.

\section{Marmara Ereğlisi LNG Regasification Terminal}

It is processing Algerian and Nigerian LNG at full capacity of $6 \mathrm{Bcm} / \mathrm{yr}$.

\section{Aliaga LNG Regasification Terminal}

It belongs to a private company and it has $5 \mathrm{Bcm} / \mathrm{yr}$ regasification capacity.

Above all pipelines (Table 4.1) within the Turkey and the Marmara Ereğlisi, LNG regasification terminal is owned and operated by BOTAS. Currently, Turkey has 61 $\mathrm{Bcm} / \mathrm{yr}$ import capacity. Of this, $50 \mathrm{Bcm}$ is via pipeline and $11 \mathrm{Bcm}$ is in the form of LNG. Pipeline import capacity could be increased up to the $74 \mathrm{Bcm} / \mathrm{yr}$ with enhancements in pipelines such as installation of more compression systems and looping of some sections. This means that Turkey will not have import infrastructure 
problem and could meet its future domestic needs with enhanced existing pipeline system if it does not take balanced diversification into account.

Turkey has $12 \mathrm{Bcm} / \mathrm{yr}$ export capacity via TGI. Two pipelines Iran-Turkey line and BTE line are connected to the European Gas market via TGI: Through these lines Turkmenistan, Iran, and Azerbaijan gained physical link to Europe with the volume restricted to the capacity of Turkey-Greece Interconnector. It is correct to say that the small part of the Fourth Corridor has been realized and Turkey is a small scale transit hub country. When Greece-Italy Interconnector ("Poseidon") is constructed this line will work more effectively at its capacity of $12 \mathrm{Bcm} / \mathrm{yr}$.

\subsubsection{Proposed Pipelines}

This section is related to the main artery pipeline Nabucco within the Fourth Corridor and regional pipelines in operations and to be constructed to feed the Nabucco in Turkey. But, accomplishment of the objective will be dependent on the realization of regional pipelines with sufficient quantity of gas if the commerciality is a prerequisite for Nabucco.

\section{Nabucco Import Route}

It is the main artery of Fourth corridor (Figure 4.6). It is intended to secure supplies to the transit countries whose national companies are the shareholders of the project, Turkey, Bulgaria, Romania, Hungary and Austrian trading hub in Baumgarten. Nabucco main trunk line is designed to aggregate the gas in Turkey coming from surrounding producers and to transport it to the final destination. It is 3,300-kilometres (2,050-mile) running from Turkey via Bulgaria, Romania, and Hungary to Austria. Construction is scheduled to begin in 2009, with the completion date set for 2013 to be started with estimated 8 Bcm/yr initially. The eventual capacity will be $30 \mathrm{Bcm} / \mathrm{yr}$. However, it is likely that start-up date of pipeline, if it is realized, will be no earlier than the Shah Deniz Stage II development.

The most important feature of the Nabucco is that it will not contract gas but it will only carry the supplier's gas [94] that will come through below described potential regional export lines from Azerbaijan, Turkmenistan, Iran, Iraq, and Egypt. But with 
the exemption from the EC, the shareholders will also have a capacity in the Nabucco to carry their gas.

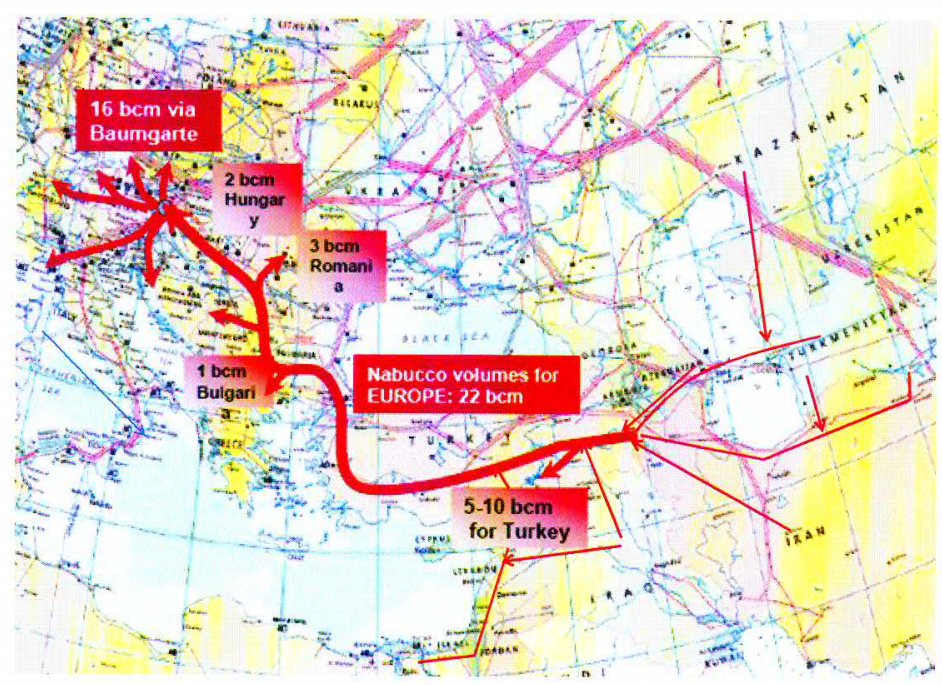

Figure 4.6 Nabucco Pipeline [93]

\section{Azerbaijan Gas: Baku-Tbilisi-Erzurum Pipeline}

The uncontracted volume of Azeri gas to be exported is expected to be a maximum of average $13 \mathrm{Bcm} / \mathrm{yr}$. The expected time for the export will be no earlier 2014 with the volume of $4 \mathrm{Bcm} / \mathrm{yr}$ from Shah Deniz stage II gas. The volume will increase to $13 \mathrm{Bcm} / \mathrm{yr}$ after 2016 if the timely inclusion of ACG deep gas into the process is realized. Azerbaijan at a state level and the project partners is ready to send the gas to the EU via Turkey. But the volume of the gas will change depending on Turkey's domestic need. It is likely that Azerbaijan, considering the potential maximum export volume, will choose TGI. In September Greece and Azerbaijan came into conclusion for the export of gas to Greece by TGI but volume has not been disclosed yet. If first gas goes to Greece and / or Italy and Turkey, this will postpone the Nabucco project unless additional gas from other sources is supplied. 


\section{Turkmenistan Gas: Trans-Caspian and Turkmenistan-Iran Line}

The EU and the US are trying to reactivate the export of Turkmen gas via the Caspian Sea to Azerbaijan then to the EU via Turkey. But this project is still problematic.

Turkey's wish to be a transit country began in 1991 with an offer to Turkmenistan to transport Turkmen gas to the west. After numerous bilateral and multilateral talks and signing of number of protocols between Turkmenistan, Iran and Turkey for 5 years concerning the construction of main export pipeline to the West, the first important MoU to send the Turkmen gas to the west via Iran was signed between the presidents of three countries Turkmenistan, Iran and Turkey in Askaabat during the ECO meeting in May 1997.Turkey in the same time duration signed an agreement with Iran in August 8, 1996 and the Blue Stream gas export agreement with Russia in late 1997.

However, The US opposed the Turkmen export project via Iran with the argument that it considered Iran as a competitor, and not as a partner and exporting Turkmen gas via one competitor meant somewhat to become hostage of it [95] and recommended an alternative route through the disputed Caspian Sea to Azerbaijan named as Trans Caspian project (TCP). On December 19, 1997 the US and Turkey signed an agreement ensuring global energy security and diversity, helping to diversify Turkey's gas supplies, transporting regional oil and gas resources through Turkey to the international markets. Today Turkey, as said by Davutoglu "... as far as cooperation with the US in the field of energy concerns, the joint project on the Trans Caspian as well as strategic approach for energy security in global economy will be maintained in the most effective way..." [96], is continuing its partnership with the U.S.

When Turkey signed the Blue Stream Agreement Turkey was accused of ruining the TCP project since it was assumed that there was no more available volume for Turkmen gas in Turkey. On the contrary, Turkey after the Blue Stream agreement increased the volume of gas to be purchased from Turkmenistan compared to that of before ( $8 \mathrm{Bcm} / \mathrm{yr}$ ) and made an official offer also to purchase the rest of gas from Turkmenistan to re-export to Europe. Within that concept, Turkey talked to several European Countries such as Hungary in May 1998, and Austria later to re-export Turkmen gas. The Hungary was very explicit to say that it wanted to buy directly 
from the suppliers. This preference of the buyer is still valid today on the consumer state and the EU level.

The last and valid agreement with Turkmenistan is the one signed on October 29, 1998. This agreement included re-exports right which is not acceptable by the buyer. However BOTAS is not hopeful for the re-activation of this contract [97].

In the end, the project was postponed. In fact, the major bottleneck for the postponement of TCP was not only the Blue Stream Agreement, but it was also due to the fact that a) Azerbaijan requested a very high transit fee as well as high volume capacity in the pipeline crossing Azerbaijan after Shah Deniz discovery, b) there was dispute between littoral states in the partition of Caspian Sea and environmental concerns were raised by Iran and Russia and $c$ ) Turkmenistan assumed legal rights for the Azeri part of Azeri-Charig-Ghunesli (ACG) project in operation and Serdar/Kepez block which is in idle position presently due to the reason in item $b$ above.

As of today, the realization of this project, to a great extent, does not seem possible for additional reasons that Azerbaijan is no more interested in that project as a transit country; Azerbaijan assumes that solution of the problems related to crossing of Caspian Sea and transport of Turkmen gas to Europe is just the problem of the EU; and Azerbaijan also states that Turkey essentially does not need Turkmen gas and Azerbaijan can give gas to Turkey from Shah Deniz phase II. In this case, the latest approach between Azerbaijan and Turkmenistan will be no more than a political show.

Under the light of chapter 3 and above mentioned additional political difficulties, Turkmen gas is not seen as a possible source to fill Nabucco.

\section{Iran Gas: Iran-Turkey Line}

Iran and Turkey on July 13, 2007 signed a Memorandum of Understanding on production, export and prices of the natural gas extracted from Iran's South Pars field. A part of the gas will be used in Turkey and a part will be exported to Europe. According to the Agreement, Turkey will invest $\$ 3.5$ billion in South Pars gas deposits. 
Although Hilmi Guler, The Minister of Energy of Turkey described this MoU as an important step to meet the EU's gas need and to enable Turkey to become a Corridor Country, the EU ruled out the supply of Iranian gas to the Nabucco pipeline due to international sanctions. This also was reiterated by Austria [94].

However, the reality in the MoU is somewhat contrary to what has been thought by Turkish Officials and it has arisen from misunderstanding. First there will not be any gas allocation to Turkey in field development since the nature of Buy-Back contract does not let; second in case TPAO gets the right to develop the blocks in South Pars, the whole production will be utilized for the increasing domestic needs of Iran [98], third if BOTAS wants to purchase gas, sales will be realized on the Turkey/lran border on the base of European level netback price with no re-export right [98]. Iran itself wants to export to the EU directly and would like to use Turkey just as a transit county.

However, at the EU level there is no room for Iranian gas as long as current international political risk in Iran continues.

\section{Iraq Gas: Iraq-Turkey Export Line}

If a small scale study in the early 1980 s to transport the $2 \mathrm{Bcm} / \mathrm{yr}$ associate gas from the Kirkuk area of Northern Iraq to Batman-Turkey is not taken into consideration, the large scale gas export project to meet the Turkish domestic needs was initiated in 1995 through the Mansuriyah gas field development with the capacity to produce $3 \mathrm{Bcm} / \mathrm{yr}$ by TPAO to be exported to Turkey. On March 8, 1996, The Ministry of Oil of Iraq and the Ministry of Energy of Turkey signed a memorandum of Understanding in Ankara to study the feasibility of building a Gas Export Project from Iraq to Turkey with the inclusion of 4 more fields by Iraq. Iraq and Turkey formed a gas export project group in Iraq and Turkey for the project. Turkish side comprised of TPAO, BOTAS and TEKFEN under the responsibility of TPAO. The study concluded the feasibility of gas export project based on development of five free gas fields capable of exporting $10 \mathrm{Bcm} / \mathrm{yr}$.

The Iraqi and Turkish sides have opened dialogue with many upstream and gas transport companies for the implementation of the projects and in the end, ENI of Italy as an operator company for Upstream and Gas de France for the midstream 
coordinator was chosen by Iraq. The project did not continue further because of the UN sanctions imposed.

Iraq-Turkey Gas Export Project in 2003 was heated up by Shell in a larger scale with the aim of utilizing all free and associate gas of Iraq in the domestic market and exporting the rest to Europe. Shell invited the Turkish side into the project upon recommendation by Iraq. This alliance lasted 3 years without benefit.

The last business development team was set up in the summer of 2007 among Iraq, Turkey and the US to export the Iraqi gas to Europe. But, which gas this team will try to export is not clear. The reasons are as follows: a) since majority of the free gas fields belonging to the Iraq-Turkey gas export project were allocated in the Northern Iraq for power generation, the known gas export project is dead. Today in the Northern Iraq, two middle size gas fields are left to be developed: Akkas and Mansuriyah. It is likely that these two fields will be connected to the Syrian grid for Arab Gas Pipeline; b) the associate gas is abundant in the Southern Iraq and this gas will be developed for internal use of southern Iraq and export to Gulf States.

So, recent developments in Iraq, as were described in Chapter 3, somewhat indicate that Turkey is about to lose in that project in spite of BOTAS's announcement that it started a feasibility study for Iraq-Turkey natural gas pipeline In the medium term, Iraqi gas may come to Turkey via Syria at a small amount.

\section{Egypt and Iraq Gas: Arab Gas Pipeline}

Turkey following the First Protocol signed on February 2, 2000 for $4 \mathrm{Bcm} /$ year gas to meet a part of its supply deficit has signed a Framework Agreement with Egypt in February 2006. According to the Agreement, Egypt will export 2-4 Bcm/year gas to Turkey for internal use and 2-6 Bcm/yr to Europe via Turkey when Arab Gas Pipeline (AGP) is ready. Turkey is expecting to get the gas by the end of 2011 [91].

The EU has agreed gas deliveries of $7 \mathrm{Bcm} /$ year with Egypt and Iraq. Egypt has agreed to supply the EU with $2 \mathrm{Bcm} / \mathrm{yr}$ gas when the pipeline is ready and Iraq will supply around $5 \mathrm{Bcm} / \mathrm{yr}$ by 2011 when Akkas field is producing sufficient quantity [99]. 
In Syria in 2006 the Euro-Arab Mashreq gas market project, funded by the EU, was established. The concept of the project is to integrate the gas markets of Egypt, Jordan, Lebanon and Syria in view of creating a regional internal market [100]. The AGP in the first phase connect these above states and will be linked to Iraq for additional sources since Egypt will [101] not be able to support the market much. This market in the future through Nabucco and other Trans -European pipelines will be connected to the EU.

Taking into consideration the above market development, it can be said that: firstly, priority will be given to the regional consumption before reaching the EU; secondly, the annual rate of Akkas field will be around $4 \mathrm{Bcm}$ and according to Iraqi party of it will be consumed in Syria and rest will be connected to AGP for Europe. At the same time, the projection [102] shows that Syria will face a deficit of $5 \mathrm{Bcm} / \mathrm{yr}$ in 2011 and $10 \mathrm{Bcm} / \mathrm{yr}$ in 2015, including the import from Egypt. Considering this deficit in Syria, the contribution of AGP for Nabucco will be much less that $7 \mathrm{Bcm} / \mathrm{yr}$ even may be confined just to the gas of Egypt with $2 \mathrm{Bcm} / \mathrm{yr}$. In this case the Mansuriyah field (with capacity of $3 \mathrm{Bcm} / \mathrm{yr}$ ) in Iraq can be connected to Syria; and thirdly, all these will mean that Iraq will be connected to the regional markets through Syria.

The total gas volume through AGP will be no more that $5 \mathrm{Bcm} / \mathrm{year}$. Of this $2 \mathrm{Bcm} / \mathrm{yr}$ will be from Egypt and 3 Bcm/yr from Iraq at a date no earlier than 2012.

As a result, the contribution from surrounding producers to Turkey is expected to be $18 \mathrm{Bcm} / \mathrm{yr}$. Of this $13 \mathrm{Bcm} / \mathrm{yr}$ will be provided by Azerbaijan, and $5 \mathrm{Bcm} / \mathrm{yr}$ by AGP that will bring gas from Iraq via Syria and from Egypt. If Turkey would like to meet its deficit out of this volume, the total volume to be transported to the EU will be no more than $13 \mathrm{Bcm} / \mathrm{yr}$, just sufficient to fill the TGI. In this case, if AGP is realized it is likely to be connected to the EU via TGI. This will make Turkey a small scale transit gas hub Country. 


\section{CHAPTER 5}

\section{RESULTS AND DISCUSSIONS}

At present, $61 \%$ of the consumption in the EU is covered by the external imports, mainly from Russia, Norway, and Algeria via pipeline accounting for $84 \%$ of the imports. $16 \%$ of imports belong to LNG. In the future, import dependency will increase to $84 \%$ in 2030 .

The security of supply due to increasing import dependency has been on the agenda of the EU. As indicated in the Green Papers, the European Commission stresses four points: diversification in fuel mix internally, completion of internal market, diversification in source and route externally, and common policy.

The European commission within the concept of diversification in source and route for the long term supply security attaches importance to Turkey and supports it as a potential transit country, taking into consideration Turkey's geographic location between the_consumer EU and the producers Central Asia and Gulf.

However, it is anticipated that due to latest policy developments by the EU on energy efficiency, increase in the use of renewable, and plans by several states to return to nuclear energy and clean coal with the developments of carbon capture and storage, demand for natural gas is expected to decrease after 2020. This potential decreasing trend in demand combined with the low import gap (uncontracted gas volume) and the developing single internal gas market will make import dependency for the EU less critical in future. But, regardless of this finding, the EU supports the Fourth Corridor for the security of supply of CEE region in the medium term.

At the same time, realization of the status of Turkey as a transit country will to a great extent be dependent on the policies and the priorities of the supplier countries and Russia's energy strategy. The Russian strategy calls for an expansion of Russia's presence in Central Asian gas projects and the increase of gas flow to 
Russia. Moreover, Russia with its existing infrastructure and with its historical and traditional personal ties took the initiative in Central Asia to maintain its sole transporter role to Europe.

Kazakhstan, due to its geography and traditional links to Russian gas infrastructure, preferred the Russian market. The biggest condensate field Karachaganak that contributes to the half of Kazakhstan's sale gas is currently exported to Orenburg Process center (Kazakhstan has already purchased $50 \%$ of this center).

Uzbekistan is likely to focus on domestic and regional export markets in addition to Russia as the main market.

Turkmenistan has emerged as the leading potential natural gas exporter and a key player in the region. Turkmenistan has two outlets: through Iran and through Azerbaijan crossing the Caspian Sea for direct access to the markets other than via Russia. The US, since the late 1990s, in order to break the Russian transportation monopoly and to isolate Iran, has initiated the Trans-Caspian pipeline project that crosses the Caspian Sea to reach Azerbaijan then to the EU via Turkey. However, until today, neither this project, due to the legal dispute for the partition of Caspian Sea nor Turkmenistan-Iran-Turkey project, due to the US opposition, have been realized. Not limited to above geopolitical constraints, Turkmenistan today does not have any surplus export capacity for the West since its current export commitments to Russia, China, and Iran are well over its production. Any change in the reserve estimation that will be clear after the result of audit conducted by one independent international firm upon the invitation of Turkmenistan will only help Turkmenistan to increase its production to balance the current export obligations of $144 \mathrm{Bcm} / \mathrm{yr}$ at plateau rates.

In addition, the Russian initiative to increase the Central Asian border prices of gas made the efforts for Trans-Caspian project useless in terms of commerciality. Delivering gas to Europe over Turkey at a price competitive with alternative Russian supplier will be difficult to achieve and may result in net-back gas prices well below than Russia agreed with Central Asian producers. 
Azerbaijan, with the help of its geography, made its direction clear, which is towards west. However, the export capacity of Azerbaijan will be around $13 \mathrm{Bcm} / \mathrm{yr}$, meaning that it may only fill TGI line to Greece.

Iran has external and internal constraints to be an exporter. This country has been under the U.S. sanction since 1995 and under UN Security Council economic embargo since 2006 due to its nuclear program. Today, Iran has a limited gas production due to two decades of underinvestment. The rate of growth in development of gas resources hardly does match the rate of increase for internal demand. The international political situation and insufficient production will not let Iran be an exporter at the medium-term.

Iraq will be a small scale exporter to the EU via Turkey due to several reasons: a) although Iraq has large amount of gas reserves, it is mainly associated gas and utilization of that gas will somewhat depend on the development of oil fields; b) the majority of oil fields are located in the southern part of country and agreement has already been signed to utilize that gas for the need of southern part of Iraq and for the export to southern neighbors; $c$ ) the major amount of limited free gas reserves in the north is allocated to the need of northern part of Iraq; d) so, the capacity of reserves in the northern part to be developed for the export purposes to Syria for its growing needs and to the EU is restricted to maximum $7 \mathrm{Bcm} / \mathrm{yr}$ ( of this $4 \mathrm{Bcm} / \mathrm{yr}$ will come from Akkas gas field and $3 \mathrm{Bcm} / \mathrm{yr}$ will come from Mansuriyah gas field). Considering the increasing supply gap in Syria, it is anticipated that the amount of gas to head for the EU will be no more than $3 \mathrm{Bcm} / \mathrm{yr}$.

Egypt has already stated that it would only allocate $2 \mathrm{Bcm} / \mathrm{yr}$ for the Europe.

Under the light of the above, the volume that suppliers might transit via Turkey will be $18 \mathrm{Bcm} / \mathrm{yr}$ (Table 5.1).

Turkey is expected to face a supply gap amounting from 4 to $5 \mathrm{Bcm} / \mathrm{yr}$ starting before 2015 to $14 \mathrm{Bcm} / \mathrm{yr}$ by 2020. If Turkey would like to secure that deficit out of this transit gas, the gas that will flow into the EU will be confined to maximum13 $\mathrm{Bcm} / \mathrm{yr}$ that is just enough to fill one pipeline that is likely to be the partly constructed Turkey-Greece-Italy pipeline. This quantity of gas will not be enough to make 
Nabucco pipeline economic to earn satisfactory rates of return over the expected range of tariff.

Table 5.1 Export possibilities of producing countries for the EU, Bcm/yr

\begin{tabular}{|l|l|l|l|l|l|l|}
\hline Bcm / yr & Russia & $\begin{array}{l}\text { Central } \\
\text { Asia }\end{array}$ & Iran & Turkey & China & Europe \\
\hline Russia & & & & & & \\
\hline Kazakhstan & $15,2 / 16^{*}$ & & & & $10^{* *}$ & \\
\hline Uzbekistan & 10,5 & 4,2 & & & & \\
\hline Turkmenistan & $41,2 / 90^{*}$ & & $9,2 / 14^{*}$ & & $40^{*}$ & \\
\hline Azerbaijan & & & & 6,6 & & $13^{* *}$ \\
\hline Iran & & & & $6,2 / 10^{*}$ & & \\
\hline Iraq (via AGP) & & & & & & $3^{* *}$ \\
\hline Egypt (via AGP) & & & & $4^{* * *}$ & & $2^{* *}$ \\
\hline \multicolumn{2}{|c|}{ * Contracted Volume ** Potential Export } & *** Possible Export \\
\hline
\end{tabular}

The Ministry of Energy and Natural Resources of Turkey believes that being active in an upstream development in surrounding producer countries is important for Turkey to have the physical ownership of the gas to be produced by Turkish companies, especially by state-owned company TPAO for the reasons of securing the Turkish domestic demand and the volume for the Fourth Corridor pipelines, specifically Nabucco. This policy goal has been expressed by BOTAS lately too. However, especially because of two reasons, it is not possible to accomplish the goal. The reasons are the fiscal and export policies of producing countries and the technical financial and managerial capabilities of TPAO in carrying out the challenging projects. Firstly, in the neighboring producing countries, gas export is under government control and producer is not free to dispose its gas due to the fact that a) nature of contract is service type as is in Iran and Iraq where gas belong to state and export is realized by state, b) although nature of contract is PSA type, there is a specific government policy that gives exclusive right to state to purchase gas from producers to be exported solely by state as is in the Kazakhstan and Egypt or that requires a offtake agreement with a state-owned company designated by State as is in Turkmenistan. As for Azerbaijan, nature of PSA type contract and 
government policy permit any producer to export its gas freely. However, individual sale, if development is realized by a consortium, is not preferable due to difficulties to meet volume commitment. For that reason, collective export mechanism is essential as is in Shah Deniz and ACG deep gas projects. As a result, the above circumstances will restrict the ability of TPAO to export the gas it may develop. Secondly, Oil industry developments clearly indicate that most efficient development and production operations of the proven reserves after their discovery are very important. Producing countries are preferring companies with strong operational experience in manpower and with extensive expertise of applying advanced and innovative technologies in enhancing hydrocarbon recovery efficiently. Unfortunately, TPAO, technologically and managerially including manpower, remains behind the international standards to develop oil and gas fields in a cost effective manner. Unless company level internal and ministry level external constraints that impair TPAO's effectiveness are solved, utilization of TPAO as a regional upstream actor to accomplish any goal is not possible under normal industry conditions, disregarding politically motivated projects. 


\section{CHAPTER 6}

\section{CONCLUSION}

This study argued the ambition of Turkey about whether it will be able to become a major transit gas hub, namely the Fourth Corridor country to play a role in the diversification of the EU's gas imports, with its advantageous geographical situation in relation to the producers Azerbaijan, Central Asia, and the Gulf region. The decisive factors for the realization of this wish have been dependent upon the priorities of the demand side, the European Union and the producing side that was listed above.

Developing gas oriented energy projects, the EU with the evolution of demand and the decrease of indigenous production faces a security of supply at a different strength on regional basis. While, for the main consuming Member States (the EU15) located in the Western Europe, the import dependency is seen less critical and not a problem through evenly diversified import portfolio, for the Member States (the last EU-12) located in the Eastern Europe the situation is a little worse through high dependency to one supplier. In this respect, a) completion of competitive single gas market that will let gas flow continuously throughout Europe and that will link isolated asymmetric, in dependency, regional markets to each other to prevent short time supply disruption and to create a liquid spot market to foster short term supply security, and b) reaching new alternative sources to enhance the long term security of supply has been on the agenda of the EU and Turkey has been perceived as an important transit country by the EU for the flow of alternative sources located in the above indicated producing regions to the European markets, . The EU at the institutional level is committed to provide a political support for the Fourth Corridor concept.

As for the supplier side, source countries subject to this study have been a center of attraction by the global and regional actors. 
Azerbaijan, due to its geography, preferred the western market via its already constructed transport infrastructure. It is expected that approximately $13 \mathrm{Bcm} / \mathrm{yr}$ gas will flow to the EU via Turkey.

Central Asia, due to the lack of independent transport infrastructure apart from lines of Soviet legacy, has only a single choice via Russia to export its gas in a westerly direction. Kazakhstan and Uzbekistan preferred to sell their gas to Russia. Turkmenistan had already taken the same action through a long term sale and purchase commitment with Russia. Turkmenistan in addition has an agreement with Iran and China to meet their internal needs. There was also a weak possibility that Turkmenistan would export gas to the EU via either Iran or Caspian Sea bypassing Russia. However, political and environmental difficulties have not given Turkmenistan this chance. So, the reserves of Central Asian states have already been booked, to a great extent, by Russia, China and to a small extent by Iran. While Central Asian producers enable Russia to service its European contracts, Russia lately strengthened its stand with the new European level purchase pricing policy that will make the net-back values of Central Asian producers' gas much higher than what might be via new pipeline routes to the EU bypassing Russia. So, the export opportunity in Central Asia towards the EU via alternative routes is a weak possibility.

Gulf States Iran and Iraq due to internal and external problems have difficulties in utilizing their reserves for the export. Iran, due to the political and economic obstacles and high domestic natural gas consumption as a government policy with subsidized gas prices, has no ability for new export opportunities other than the current one to Turkey. Moreover, any export initiation towards west by or via Iran will be determined by the role of the U.S. This affected also the export policy of the EU from Turkmenistan for the western market. Iraq, on the other hand, has security problems. But not considering the security, activities to export gas to the European market will be confined to utilizing, unfortunately, small scale free gas reserves from one of two gas fields in the Northern Iraq. This gas is thought to be exported firstly to Syria to fill the growing demand gap in Syria and secondly to the EU. Main volume of Iraqi gas will be imported by Syria. The rest of gas (approximately $3 \mathrm{Bcm} / \mathrm{yr}$ ) will go to EU through Arab Gas Pipeline coming from Egypt via Syria to Turkey to be connected to either TGI or Nabucco in Turkey for the EU market. 
Gas from Egypt to reach Syria and then Turkey via Arab Gas Pipeline and then the EU is also included in the supply portfolio of the EU, with $2 \mathrm{Bcm} / \mathrm{yr}$ small quantity of gas as Egypt explicitly stated.

As a result, under these circumstances, except the already flowing Azerbaijan gas and small scale Egyptian gas combined with the Iraqi gas to be available after 2012, there will be no additional flow through Turkey, meaning that the export of significant gas volume from producing countries indicated in this thesis to the EU via Turkey is unlikely to make Turkey major gas transit hub. Taking into consideration also the need of Turkey that she may request to meet part of its demand out of that gas, within the next decade Turkey will only be the small scale gas transit hub country merely utilizing Turkey-Greece Interconnector. 


\section{REFERENCES}

1 Manfred Hafner, "Oil and gas supply-demand scenarios for Europe up to 2030",NEEDS Forum 2, Krakow,5-6 July 2007.

2 European Commission, Directorate General for Energy and Transport, "European Energy and Transport, Trends to 2030-Update 2005", May 2006.

3 "Reliance on Russian gas will persist", Financial Times, September 4, 2008.

4 IEA, "Security of gas supply in open markets", 2004.

5 European Commission, Directorate General for Energy and Transport, "European Energy and Transport, Scenarios on high oil and gas prices", September

2006

http://ec.europe.eu/dgs/energy transport/figures/scenarios/doc/2006 scenari os oil gas en.pdf, (January 2007).

6 Commission of the European Community, "Communication from the Commission to the European Council and the European Parliament ,"An Energy Policy for Europe", (SEC(2007) 12), Brussels, January 10, 2007.

7 BP statistics, 2007.

8 Jonathan Stern, "European Gas Security: what does it mean and what are the most important issues?", CESSA Conference, cambridge, December 14, 2007.

9 Agata Loskot-Strachata, Katarzyn Petczynska Nalecz, "The Gazprom's expansion in the EU", Center for eastern studies,Warsaw, April 2008.

10 Susanna Nies, "Oil and Gas to Europe", IFRI Energy Program, Brussels, February 27, 2008.

11 William C. Ramsay, "Security of Energy Supply in the European Union", IEA, castle Melnik, May 31, 2007. 
12 R.W. Grabham, "EU Gas Supply - Demand Scenarios", European Union Russian Federation Energy Dialogue, Moscow, October 30, 2006.

13 Susanna Dorigoni, Sergio portotadino, "LNG development across Europe: Infrastructural and regulatory analysis", working paper no:12, May 26, 2008, www. iefe.unibocconi.it, (May 2008).

14 http://www.nabucco-pipeline.com, ( January 2008).

15 Commission of the European Communities, Green Paper, "Towards a European Strategy for the Security of the Energy Supply",Brussels, November 29, 2000.

16 Commission of the European Communities, Green Paper "A European Strategy for Sustainable, Competitive and Secure Energy",Brussels, March 08, 2006.

17 http://ec.europe.eu/energy/gas/legislation, ( January 2008).

18 http://ec.europe.eu/energy/comm/competition, (January 2008).

19 Benita ferrero-Waldner,"Towards an EU External Energy Policy to assure a High Level of Supply Security", Speech/06/710, Brussels, November 20, 2006.

20 Commission of the European Communities, "Communication from the Commission to the Council and the European Parliament, European energy infrastructure", 2001.

21 The European Commission, TEN-E Priority Projects, 2004, http://europe.eu.int/comm/dgs/energy transport/index en.html, (June 2007).

22 "An External Policy to serve Europe's Energy Interests", paper from Commission/SG/HR for the European Council, released in June 18, 2006.

23 Micheal Sander, "A strategic relationship? The German Policy of Energy Security within the EU and the Importance of Russia", Dealing with dependency, Edited by Marco Overhaus at.all, Foreign Policy in Dialogue, Volume 8, Issue 20, Trier, Germany, January 11,2007, http://www.deutscheaussenpolitic.de, (January 2007). 
24 Pierre Noel " The west should not go strategic on energy issues", January 11, 2008, Financial Times.

25 Ernest Wyciszkiewicz, "One for all-all for one-The Polish perspective on external European energy", Dealing with dependency, Edited by Marco Overhaus at. All, Foreign Policy in Dialogue, Volume 8, Issue 20, Trier, Germany, January 11, 2007, http://www.deutsche-aussenpolitic.de, (January 2007).

26 "Nabucco- a hint of eastern Promise", Gas Matters, June 28, 2005.

27 Abbas Maleki, "Iran and European Union Cooperation in Caspian Sea, Central Asia, and Caucasus", Roundtable, Institute for Caspian Studies, March 11, 2007.

28 CERA Eurasia gas export outlook, August 2007, http://www.cera.com, (August 2007).

29 Dr. Viladimir Paramonov, "The future supply of gas from Central Asia to Russia: an expert assessment", Advanced Research and Assessment Group 08/05, February 2008.

30 Natural gas pipelines of the former soviet union, Center for Global Energy Studies.

31 RGI 2006 Overview, June 13, 2006, http://www.eegas.com, (June 2007).

32 IHS, Russia Annual Synopsis, 2007.

33 "The Summary of the Energy Strategy of Russia for the Period up to 2020",Ministry of Energy of the Russian federation, Moscow, 2003.

34 Gazprom website: http://www.gazprom.ru, (September 2008).

35 "Russia and the Global Natural Gas Market", Asset Capital Partners, March 2008.

36 "EU nervous as Russia eyes new energy markets", www.euractiv.com , (September 2008). 
37 The Russian-European Union Summit Joint press Conference, June 27, 2008 www. kremlin.ru, (August 2008).

38 Ria Novosti, June 23, 2008.

39 The future of Gas Exports from Russia, Management report, Russian Petroleum Investor Inc., 2002.

40 IEA," Optimizing Russian Gas, 2006.

41 "TPA for Russian associated gas could produce additional $38 \mathrm{gm3}$ ",ICIS, European Gas Markets, July 31, 2008, www.icisheren.com, (August 2008).

42 Robert Dudley, "Recent development and current challenges in Russia", UBS conference, Moscow, November 16, 2007.

43 Interview with TNK-BP.

44 "Sechin orders access to gas pipes", july 8, 2008, www. moscowtimes. ru/article/600/42/368782.htm, (July 2008).

45 Oliver Quast and Catherine Locatelli, "Russian natural gas policy and its possible effects on Europe gas markets", energy Policy, vol:25, no 2, 1997.

46 "Gazprom Poses Challenge to the EU Nations", Financial Times, December 20, 2006.

47 Stanislaw Secrievru, "Russia's Foreign Policy Under Putin:CIS Project Renewed", UNISCII Discussion paper, No10, January 2006.

48 CERA Executive Roundtable, London, October 25, 2006.

49 IHS, Azerbaijan Annual Synopsis, 2007.

50 International Gas Reports, issue 596, April 7, 2008.

51 Internal Information, TPAO. 
52 IHS, Kazakhstan Annual Synopsis, 2007.

53 Joanna Lillis, "Kazakhstan: Energy profits bring foreign-policy heft", Transition Online, April 20, 2007.

54 "Kazakhstan studying Caspian-Europe pipe to bypass Russia, Ria Novosti, Astana, April 24, 2007.

55 "Political developments in Caspian Energy projects", KOGIG UK, Kazakhstan Oil and Gas Industry Group, June 06, 2007.

56 "Will Kazakhstan abandon the trans-caspian pipeline", KOGIG UK, Kazakhstan Oil and Gas Industry Group, June 06, 2007.

57 Kazinform, May 22, 2008, www.inform.kz, (May 2008).

$58 \quad$ IHS, Uzbekistan Annual Synopsis, 2007.

59 IHS, Turkmenistan Annual Synopsis, 2007.

60 F.Van Oostvoorn (ed.), "Long-Term Gas Supply Security in an Enlarged Europe", December, 2003.

61 "Turkmen-Gas Price Formula to Change: Iran", September 15, 2008, www.shana-ir/134213-en.html, (September 2008).

62 "Turkmenistan China agree to enlarge capacity of prospective gas pipeline, ITARTASS, September 07, 2008, www.itar-tass.com, (September 2008).

63 Internal information, TPAO.

64 "Iran concerned over Caspian pollution", September 4, 2008, www.upi.com/energy-resources, (September 2008).

65 "Russia, Kazakhstan and Turkmenistan to discuss gas-transport system", KOGIG UK, Kazakhstan Oil and Gas Industry group, May 10, 2007.

66 "EU secures gas deals", April 14, 2008, http://news.bbc.co.uk, (April 2008). 
67 Nicklas Norling, " Gazprom's monopoly and Nabucco's potential: Strategic decisions for Europe, Silk Road Paper, November 2007.

68 Jeronim perovic, Robert Orttrung, "Russia's Energy Policy: should Europe worry", Russia Analytical Digest, No 18, 2007.

69 Hedayet Omidvar, "Iran's natural gas expansion plan", IGU, April, 2008.

70 OECD/IEA "World energy Outlook 2005: Middle East and North Africa Insight, 2005.

71 IHS, Iran Annual Synopsis, 2007.

72 "The struggle the market", Petroleum Economist, May 2007.

73 "TOTAL undermines LNG hopes", Petroleum Economist, August 2008.

74 G.H. Bahmannia, "Developing Gas Markets in Persian Gulf case study: IRAN", 23th Gas Conference, Amsterdam, 2006.

75 "Gas projects worth \%31b", September 16, 2008, www.zawya.com, (September 2008).

76 Anne Karin and Gol Luft, "Ahmedinejat's Gas revolutions: A plan to defeat Economic sanctions", Institute for the Analysis of Global Security, December 2006.

77 American Iranian Council update vol.4, no:55, January 2007.

78 National Iranian Gas export company, July 9, 2008, www.nigec.com, (July 2008).

79 Fereidun Fesheraki, "Energy and Security Issues:Perspectives on Iran, India and China", Washington, DC., July 12,2007.

80 Hedayet Omidvar, "Iran and the world of natural gas", Industry Outlook, 2007. 
81 Oman offers LNG facilities", Iran Daily, September 6, 2008, www.irandaily.com, (September 2008).

82 OPEC, "Annual Statistical Bulletin", 2007, http://www.opec.org, (August 2008).

83 Ministry of Oil of Iraq, www. oil.gov.iq, ( May 2008).

84 Internal information, SHELL.

85 "SHELL eyes $\$ 2.5 \mathrm{bn}$ gas project in Iraq", January 31, 2008, http://www.iraqupdates.com, (January 2008).

86 "EU and Iraq discuss enhancing energy cooperation", February 04, 2008 , http://iraqupdates.com, (February 2008).

87 Şakir Arıkan, "Creating Transportation Solutions", presented in TUROGE 2007, March 28, 2007.

88 "Güler: Turkey will be energy bridge of EU", Hurriyet Newspaper, June 30, 2006.

89 Agata Loskot-strachota, "Nabucco vs. South stream-Rivalry over Balkan Gas Pipelines", CES Commentary, Centre for Eastern Studies, Issue 3, March 19, 2008.

90 Energy Market Regulatory Agency website: www.epdk.gov.tr, (September 2008).

91 Turkish Pipeline Corporation website: www.botas.gov.tr, (September 2008).

92 Ministry of Energy and Natural Resources website: www.enerji.gov.tr, (September 2008)

93 Reinhard Mitschek,"Nabucco Pipeline Project", $6^{\text {th }}$ Turkish Int'l Oil and Gas Conference, Ankara, March 27, 2007.

94 "Interview with Martin Bertonsten, Economy Minister of Austria",Turkish Daily News, May 23,2008. 
95 Jan Kalicki, "Kalicki details U.S. Policies, Interests in Caspian oil, EUR 307, February 021998.

96 Ahmet Davutoglu, "Turkey's Foreign Policy Vision: An Assessment of 2007", Inside Turkey, Vol.10, No:1, 2008.), Inside Turkey, Vol.10, No:1, 2008.

97 "Interwiev with the General Manager of BOTAS", PETRO GAS, August 2008.

98 Internal information, TPAO.

99 Kostis Geropoles, "EU eyes Trans-Arab gas for Nabucco", May 12, 2008, www.neurope.eu, (May 2008).

100 "Euro-Arab Mashreq Gas Market Project-Progress and Achievements", Syroil 2008, Syria, April 7, 2008.

101 "Egypt Diagnostic", December 29, 2006, http://www.eamgcc.org, (May 2008).

102 Bernard Clement, "Producing gas to Market: The end of easy gas?", Conference, Hydrocarbons and Transportation across Border,Damascus, June 19, 2008.

103 "Iraqi Oil Minister Interviewed on Contracts, Oil and Gas Law Corruption", September 30, 2008, http://www.iraqupdates.com, (October 2008). 


\section{CURRICULUM VITAE}

\section{PERSONAL INFORMATION}

Surname, Name: Umucu, Tayfun Yener

Nationality: Turkish (TC)

Date of Birth and Place: 8 July 1959, Şarkışla, Sivas

Marital Status: Married

Phone: Office: (+90) (312) 2073245

e-mail: umucu@tpao.gov.tr

\section{EDUCATION}

$\begin{array}{lll}\text { Degree } & \text { Institution } & \text { Year of Graduation } \\ \text { M.Sc } & \begin{array}{l}\text { The University of Texas at Austin, USA } \\ \text { Petroleum Engineering }\end{array} & 1986 \\ \text { B.Sc } & \begin{array}{l}\text { Istanbul Technical University } \\ \text { Petroleum Engineering }\end{array} & 1981 \\ \text { High School } & \text { Ondokuz Mayıs Lisesi, Samsun } & 1976\end{array}$

\section{WORK EXPERIENCE}

Year

1987 - Present

$1996-1997$
Place

Turkish Petroleum Corporation

The Ministry of Energy and Natural Resources

Director- Bilateral Economic Relations, Department of Foreign Affairs 